\title{
LAW OF THE LANDLESS: \\ THE DALIT BID FOR LAND REDISTRIBUTION IN GUJARAT, INDIA
}

\author{
by
}

Topher L. McDougal

M.S., Geography (2003)

University of New Mexico

B.A., Philosophy (2000)

Swarthmore College

SUBMITTED TO THE DEPARTMENT OF URBAN STUDIES \& PLANNING IN

PARTIAL FULFILLMENT OF THE REQUIREMENTS FOR THE DEGREE OF

\author{
MASTER IN CITY PLANNING \\ AT THE \\ MASSACHUSETTS INSTITUTE OF TECHNOLOGY
}

JUNE 2007

(C) 2007 Topher L. McDougal. All rights reserved.

The author hereby grants to MIT permission to reproduce and to distribute publicly paper and electronic copies of this thesis document in whole or in part in any medium now known or hereafter created.

Signature of Author

Department of Urban Studies \& Planning

May 16, 2006

Certified by

Balakrishnan Rajagopal

Ford International Associate Professor of Law and Development

Thesis Supervisor

Accepted by

Langley Keyes

Ford Professor of City and Regional Planning Chair, Master's Committee 


\section{TABLE OF CONTENTS}

ACKNOWLEDGEMENTS................................................................................................................................ 7

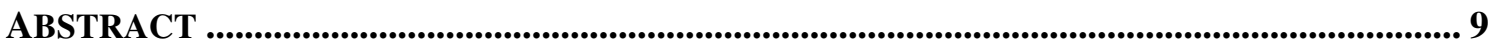

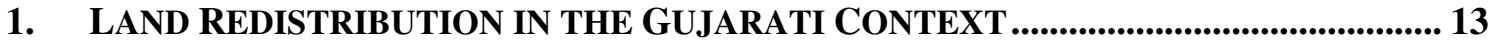

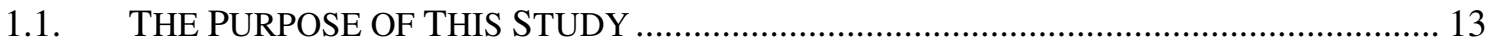

1.2. THE ORGANIZATION AND METHODS OF THIS STUDY …...................................... 16

1.3. A BRIEF HISTORY OF LAND REDISTRIBUTION IN GUJARAT

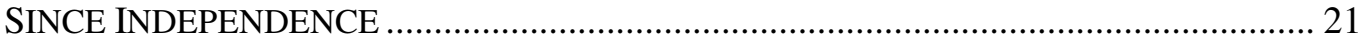

1.3.1. THE ADMINISTRATION OF POST-INDEPENDENCE GUJARAT ............................. 21

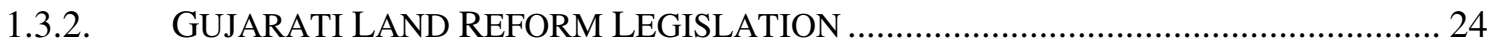

1.3.3. NAVSARJAN'S PUBLIC INTEREST LITIGATION .............................................. 30

1.3.4. A COMPARATIVE VIEW OF THE ALCA AND GOVERNMENT LANDS PROGRAM31

1.4. THEORETICAL MODELS FOR ASSESSING LAND REDISTRIBUTION INITIATIVES .. 36

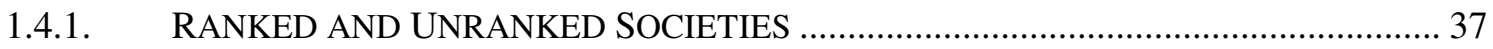

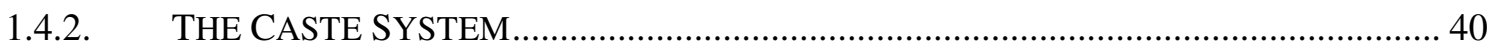

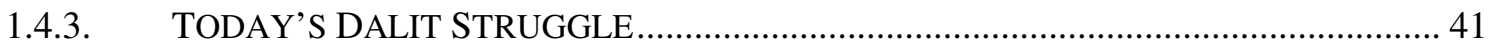

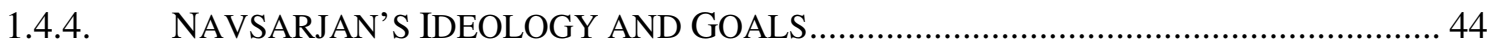

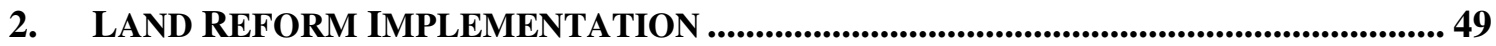

2.1. GOVERNMENT OFFICIALS \& THEIR RESPONSIBILITIES …................................ 50

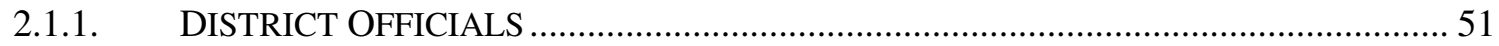

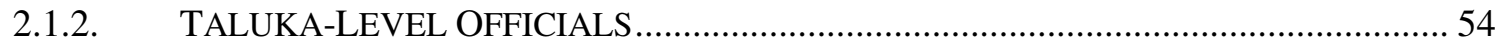

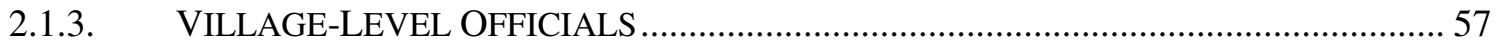

2.1.4. THE BUREAUCRATIC SYSTEM AT WORK …..................................................... 58

2.2. A SIMPLIFIED ANALYSIS OF GOVERNMENT'S IMPACT ON REDISTRIBUTION ...... 59

2.2.1. GENERAL TRENDS IN REGRESSION RESULTS FOR BREAKDOWN PREDICTORS63

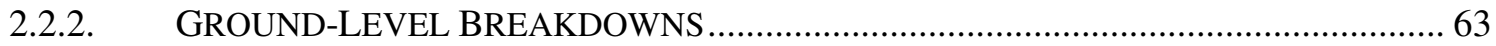

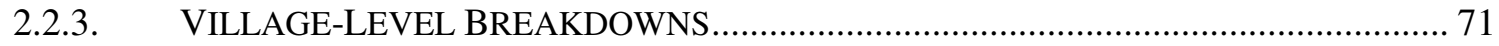

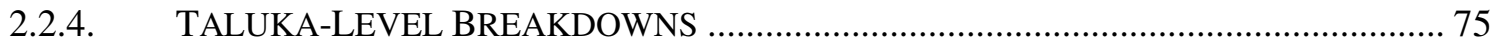

2.3. DIFFERENTIAL TREATMENT OF ALCA AND GOVERNMENT LANDS .................... 79

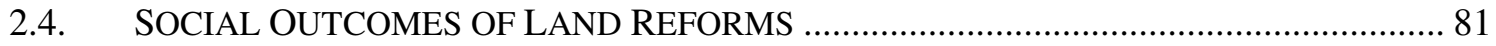

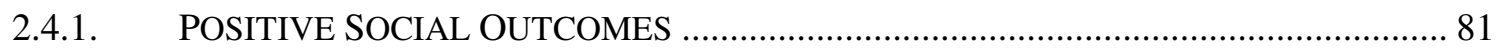

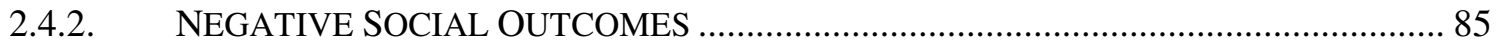

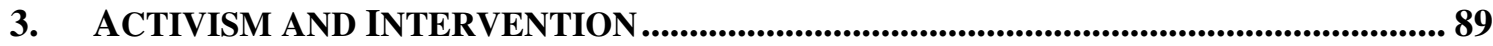

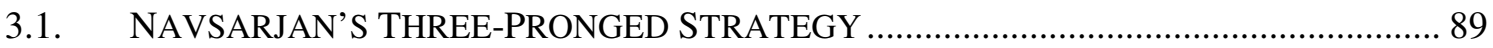

3.2. IMPLICIT CRITIQUES OF QUANTITATIVE LAND REFORM OUTCOME MODELS .... 98

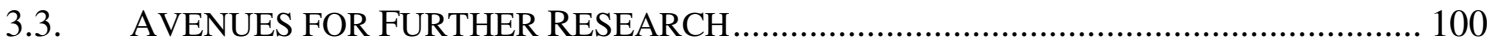

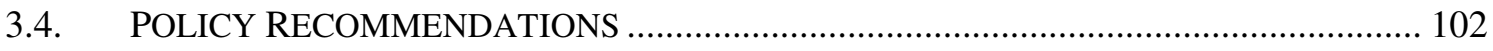

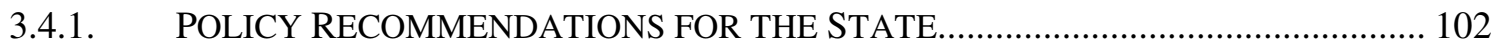

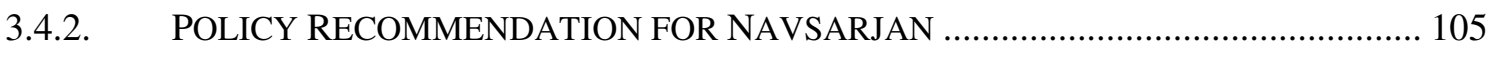

REFERENCES ................................................................................................................................................. 107

LIST OF TERMS ................................................................................................................................................... 111

APPENDIX A: COMPARATIVE LAND REDISTRIBUTION EFFORTS ...............................115

APPENDIX B: LAND REFORM IMPLEMENTATION ORGANIGRAMS...............................117

APPENDIX C: REGRESSION RESULTS FOR SECTION 2 .................................................119 


\section{LIST OF FIGURES}

FIGURE 1.3.1-1. MAP OF PRESENT-DAY GUJARAT AND ITS ADMINISTRATIVE DISTRICTS................... 23

FIGURE 1.3.2-1. LORENZ CURVES OF LAND ASSET OWNERSHIP AMONG VULNERABLE POPULATIONS

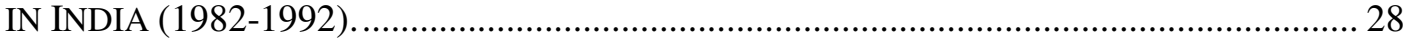

FIGURE 2.2.2-1. MAP OF SURENDRANAGAR DISTRICT DEPICTING VILLAGES, TALUKA HEADQUARTERS, AND DISTRICT HEADQUARTERS.

FIGURE 2.2.3-1.

HISTOGRAMS OF DALIT LAND RECIPIENTS SURVEYED AND SURENDRANAGAR DISTRICT AS A WHOLE.

FIGURE 2.3-1. BREAKDOWNS BY LAND TYPE AT THE TALUKA, VILLAGE, AND GROUND LEVELS. 81

FIGURE 2.4.1-1. POSITIVE AND NEGATIVE SOCIAL OUTCOMES OF THE LAND REFORMS BY LAND TYPE.

FIGURE 3.1-1.

A COMPARISON OF SURVEY RESPONSES FOR SELECTED QUESTIONS FROM 1996 AND 2006.

FIGURE B-1.

ORGANIGRAM OF THE ASSESSMENT AND SELECTION PROCESS FOR LAND

REDISTRIBUTION UNDER THE ALCA

FIGURE B-2.

ORGANIGRAM OF THE ASSESSMENT AND SELECTION PROCESS FOR LAND

REDISTRIBUTION UNDER THE ALCA

FIGURE B-3.

ORGANIGRAM OF THE IMPLEMENTATION PROCESS FOR LAND REDISTRIBUTION

UNDER BOTH THE ALCA AND GOVERNMENT LANDS PROGRAMME.

\section{LIST OF TABLES}

TABLE 1.3.2-1. PERCENTAGE DISTRIBUTION OF OWNERSHIP HOLDINGS AMONG VULNERABLE POPULATIONS.

TABLE 1.3.2-2. GOVERNMENT LANDS IN THE SOUTHERN SUB-DISTRICT OF SURENDRANAGAR DISTRICT DISTRIBUTED FROM 1960 TO DECEMBER 2006, CATEGORIZED BY RECIPIENT CASTE.

TABLE 1.3.2-3. GOVERNMENT LANDS IN THE SOUTHERN SUB-DISTRICT OF SURENDRANAGAR DISTRICT DISTRIBUTED SINCE 1960, CATEGORIZED BY TALUKA.

TABLE 1.3.4-1. LOCATION QUOTIENTS FOR GUJARAT'S REDISTRIBUTION MEASURES SORTED BY ACRES, NUMBER OF BENEFICIARIES, AND AVERAGE PARCEL SIZE.

TABLE 2.1-1. GOVERNMENT OFFICIALS KEY TO THE IMPLEMENTATION OF LAND REDISTRIBUTION LEGISLATION. 51

TABLE 2.1.4-1. 
SELECTION PROCESSES FOR LAND RECIPIENTS UNDER THE ALCA AND

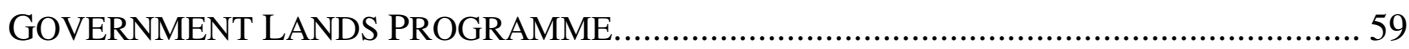

TABLE 2.1.4-2.

THE PROCESS OF IMPLEMENTING LAND REFORMS IS SHARED BY BOTH THE ALCA AND

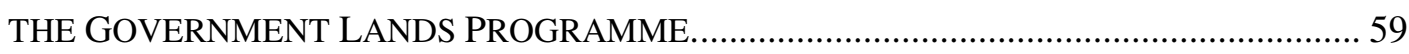

TABLE 2.2-1.

LEVELS OF SUB-DISTRICT GOVERNMENT AND THEIR POTENTIAL FOR

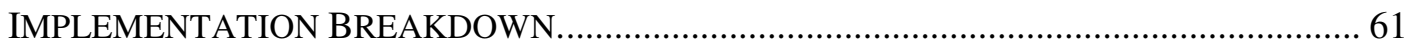

TABLE 2.2-2.

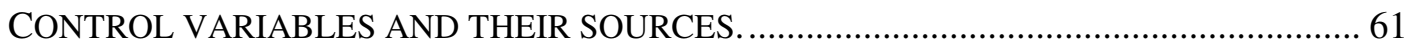

TABLE 2.2.2-1.

DETERMINANTS OF BREAKDOWNS IN REDISTRIBUTION IMPLEMENTATION AT THE

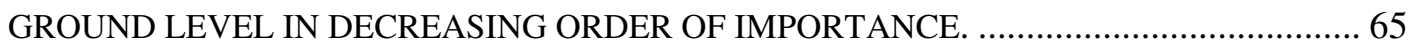

TABLE 2.2.3-1.

DETERMINANTS OF BREAKDOWNS IN REDISTRIBUTION IMPLEMENTATION AT THE

VILLAGE LEVEL IN DECREASING ORDER OF IMPORTANCE. .................................... 72

TABLE 2.2.4-1.

DETERMINANTS OF BREAKDOWNS IN REDISTRIBUTION IMPLEMENTATION AT THE

TALUKA LEVEL IN DECREASING ORDER OF IMPORTANCE (EASEMENT DIFFICULTIES

EXCLUDED).

TABLE 2.2.4-2.

DETERMINANTS OF BREAKDOWNS IN REDISTRIBUTION IMPLEMENTATION AT THE

TALUKA LEVEL IN DECREASING ORDER OF IMPORTANCE (EASEMENT DIFFICULTIES

INCLUDED).

TABLE A-1.

LAND REDISTRIBUTION EFFORTS IN VARIOUS INDIAN STATES, WITH SCHEDULED

CASTE RECIPIENTS EXTRACTED.

TABLES C-1.

REGRESSION RESULTS FOR DETERMINANTS OF BREAKDOWNS AT THE GROUND

LEVEL.

TABLES C-2.

TWO-STAGE LEAST SQUARES ANALYSIS OF THE EFFECTS OF VILLAGE-LEVEL GOVERNMENT BREAKDOWNS IN LAND REDISTRIBUTION ON GROUND-LEVEL BREAKDOWNS.

TABLES C-3.

DETERMINANTS OF BREAKDOWNS AT THE VILLAGE LEVEL

TABLES C-4.

DETERMINANTS OF BREAKDOWNS AT THE TALUKA LEVEL (WITHOUT EASEMENTS)

TABLES C-5.

BREAKDOWNS AT THE TALUKA LEVEL (WITH EASEMENTS) .................................. 123

TABLE C-6.

DETERMINANTS OF REDISTRIBUTION FAILURE 


\section{ACKNOWLEDGEMENTS}

A great number of people and institutions have supported the research that constitutes the bulk of the findings presented herein. So although I risk numbing the reader with repetition of the words "indebted," "grateful," and "appreciative," I would be remiss not to acknowledge them here.

This research would not have been possible without the enthusiastic support—both logistical and intellectual—of Navsarjan's administration and Land Redistribution Programme fieldworkers. I have rarely encountered such universal dedication to a worthy cause, and am comforted to know that they continue their work.

In particular, I would like to thank Manjula Pradip, and Martin Macwan, Navsarjan's director and founder respectively, for their insight, humor and inspiring commitment to the Dalit human rights struggle. I would also like to thank the entirety of the Land Redistribution Programme, with special recognition to those members of the Surendranagar team who endured three weeks of long car treks with me, welcomed me into their homes, and even risked their personal safety in obtaining my interviews with Darbar landlords. These include Saileshbhai D. Makavana, Maheshbhai Mohanbhai Rathod, Dineshbhai Anadhbhai Chavda, Mohanbhai Valjibhae Rathod, Dasharath P.Solanki, and Vajubhai P. Parmar. Thanks also the other members of the Land Redistribution programme whom I did not have the pleasure of working with, but who did a marvelous job with Navsarjan's original report, including Baldev, Ishwar, Jagdish, Jitendra, Kanchan, Kanta, Kanu, Kirit, Kishan, Laxman, Manji, Mukesh, Nagar, Natu, Navghan, Pravin, Ramesh, and Sankar. In addition, I owe a special debt of gratitude to Siddharth Chadha for his insights and his friendship. Many thanks also to Siddharth, Induben, Rajubhai, and Satyendra Kumar for their translation services, both linguistic and cultural. Most importantly, but perhaps least specifically, I am extraordinarily grateful to the many Dalit farmers who were brave enough to demand their rights for the sake of their families, and to share their stories with me.

In this hemisphere, I am grateful to Balakrishnan Rajagopal, director of the Program on Human Rights \& Justice at MIT's Center for International Studies, for his role as thesis advisor, academic mentor, and sometime cattle prod. My thanks also to Bishwapriya Sanyal, professor in the International Development Group in MIT's Department of Urban Studies \& Planning, for his advice during my tenure here, and his role as thesis reader.

For this project's financial support, I am most grateful to the Program on Human Rights \& Justice internship2006, the International Development Initiative grant awarded by MIT's Public Service Center, and the Emerson Travel Award, disbursed by MIT's Department of Urban Studies \& Planning.

Finally, my thanks and love go to my wife, Lotus McDougal 


\title{
LAW OF THE LANDLESS \\ THE DALIT BID FOR LAND REDISTRIBUTION IN GUJARAT, INDIA
}

\author{
Topher L. McDougal
}

Submitted to the Department of Urban Studies \& Planning on May 11, 2007 in Partial Fulfillment of the Requirements for the Degree of Master in City Planning.

\begin{abstract}
This study examines how government's implementation of land reforms in Gujarat, India informs Dalit (i.e., 'Outcaste') activism for land redistribution. It takes as a case study the Navsarjan Trust (or simply Navsarjan), a non-profit group that advocates for Dalit land rights in Surendranagar district, Gujarat. I contend that the Dalit land movement has implicitly recognized a complex reality: the outcomes of state policy on the ground are the products of a struggle between competing caste interests located within a nested hierarchy of local government institutions. I argue that Navsarjan's strategy is to modify the strength of the links between levels in this nested game-oftentimes by allowing Dalit land appeals to bypass lower, less progressive levels of government in favor of higher ones-in order to produce favorable results for the Dalit land rights movement. This strategy explodes the myth of a monolithic, intransigent state, and portrays government rather as a framework that structures social struggle.
\end{abstract}

Section 1 argues that land redistribution is seen by the Dalit activist movement as a means of verticalizing horizontal ethnic stratifications. In Section 2, I quantitatively analyze the role and effects of local government offices charged with the implementation of land reform legislation. I argue that the hierarchy of local government constitutes a nested battleground, on which the interests of Dalits and the upper-castes vie for influence. In Section 3, I examine Navsarjan's tactics in the land redistribution movement. I argue that the organization's success is largely due to its dual role as both agitator and embedded bureaucratic facilitator within the government hierarchy. I then examine qualitative evidence that could complement (and point up shortcomings of) Section 2's quantitative analysis. I conclude by examining avenues for future research and making policy recommendations for Navsarjan and for the state.

Thesis Supervisor: Balakrishnan Rajagopal

Title: Ford International Professor of Law and Development 
No collection of wealth must be made by a Sudra, even though he be able (to do it); for a Sudra who has acquired wealth gives pains to the Brahmanas.

—The Laws of Manu (tr. G. Buehler, in Mueller 1964, 430), Chapter X, Verse 28.

You know in South Africa our people are fighting for their rights. Here in India there are no laws depriving the people of the right of owning land or living wherever they please. It is true we have reduced Harijans [Dalits] to some such condition but for the rest of society that is not so.

- Mahatma Gandhi

Speaking at a prayer meeting in New Delhi

28 January, 1948

You are made to suffer want, privations and humiliations not because it was preordained by the sins committed in your previous birth but because of the overpowering tyranny and treachery of those who are about you. You have no lands because others usurped them; you have no posts because others have monopolized them. Do not believe in fate. Believe in your strength.

-B.R. Ambedkar

Businessmen, they drink my wine, plowmen dig my earth;

None of them along the line know what any of it is worth.

—Bob Dylan, "All Along the Watchtower" 


\section{LAND REDISTRIBUTION IN THE GUJARATI CONTEXT}

\subsection{The Purpose of This Study}

This study seeks to answer the question: How does government's implementation of land reforms in Gujarat, India inform Dalit (i.e., 'Outcaste') activism for land redistribution? For millennia, Dalits have been a landless people, and their struggle to bring about land redistribution speaks to the larger problem of mobilizing effectively to convert a hierarchical society into an egalitarian one. A better understanding of this process in the world's largest and most complex democracy will, I believe, prove crucial for academics and policymakers alike in designing democratic institutions intended to quell ethnic strife. Ultimately, this study aims to shed light on both the potential and the limits of redistributive policy interventions in the context of complex social realities.

The study examines the efforts of the Navsarjan Trust (or simply Navsarjan) in advocating for Dalit land rights in Surendranagar district, Gujarat. This organization is arguably the most efficacious Dalit activist group in Gujarat. A large part of its programmatic budget and scope is dedicated to the redistribution of agricultural lands from the upper-castes and state government to the often-landless Dalits. The Dalit activist movement, including Navsarjan, largely interprets Indian society's often-rigid, caste-based socioeconomic stratifications as reinforcing an inequitable economic order. It 
also contends that land tenure patterns underpin socioeconomic stratification by systematically marginalizing agricultural laborers and rendering the asset-building process slow or impossible. Critically, this struggle is embedded in two competing normative frameworks: the liberal-democratic egalitarianism espoused by the postcolonial state, and the pervasive structure of informal, caste-based codes of conduct.

I argue that Gujarati land reform activism does not follow the intuitively sensible model of activist movements in which the political actions of the state have a centralizing effect, in turn provoking countervailing reactions from the marginalized periphery (often referred to as "movement and counter-movement," as espoused, for instance, by Ercegovac [1999]). That story may well characterize activist movements dedicated to separatism. However, the Dalit activist struggle does not seek secession from Indian society, but rather its radical, egalitarian restructuring. A theory of central action and peripheral reaction cannot adequately explain the purposive formation of the Dalit land movement in the face of (a) progressive federal and state laws ostensibly fostering Dalit land rights, and (b) a robust bureaucracy charged with their implementation.

I contend that the Dalit land movement has instead implicitly recognized a complex reality: the outcomes of state policy on the ground are the products of a struggle between caste members occurring within a nested hierarchy of local government institutions. To borrow a phrase from Rajagopal (2005), local government institutions constitute a “terrain of contestation" (ibid., 183). Rajagopal argues that popular struggles have an ambivalent relationship with the law, as it may either preserve the societal and power status quo, or alternatively provide space for resistance. Rajagopal makes this argument 
in the context of social movements resorting to the courts to fight for their cause-in other words, a homegrown attempt to establish legal precedent that will effectively shape public policy from the ground up. However, in the present case, the social movement is no longer trying to shape the law from below, but to assure implementation of the law from above. Similarly, many studies have focused on rural minority efforts to influence democratic processes (see, e.g., Basu and Kohli 1998, Varshney 1995, and Kohli 2001), while relatively few have examined how policies adopted by the "empirical" state may mutate as they filter down and come into progressively closer contact with informal normative frameworks of social organization. I therefore contend that the battle waged on Rajagopal's contested terrain shifts, for the most part, from the court system or legislative institutions to the hierarchy of local governments charged with implementing legislation favorable to the social movement. I contend that Navsarjan's strategy is to modify the strength of the links between levels in this nested game—oftentimes by allowing Dalit land appeals to bypass lower, less progressive levels of government in favor of higher ones—in order to produce favorable results for the Dalit land rights movement. This strategy explodes the myth of a monolithic, intransigent state, and portrays government rather as a framework that structures social struggle. Furthermore, Navsarjan's experience hints that the role of a social movement in relation to the state is not purely antagonistic, but may also be facultative. That is, the movement may fill a functional gap in the state bureaucracy and consequently advance its own ideology and interests. 


\subsection{The Organization and Methods of This Study}

This study's main investigation is broken into three sections. Section 1 serves as a general introduction to the historical, legal, and philosophical context of Gujarati land reforms. It argues generally that land redistribution is seen as a means to verticalizing horizontal ethnic stratifications. Subsection 1.3 examines the history of Gujarati land reforms since Indian independence with special attention to state legislation aiming at land redistribution. ${ }^{1}$ In describing the legislation, I rely on the Gujarat State Codes, as well as interpretations from secondary literature. In Subsection 1.4, I describe the Marxian ideological underpinnings of land redistribution in the Dalit activist tradition that depict normative social structures as arising fundamentally from land relations.

In Section 2, I quantitatively analyze the role and effects of local government offices charged with the implementation of land reform legislation. I argue that the hierarchy of local government constitutes a nested battleground, on which the interests of Dalits and the upper-castes vie for influence. I justify the use of a quantitative analysis in what might otherwise have been a qualitative study in three ways. First, Navsarjan may choose to use this study's findings when filing future suits, and will benefit from the "hard" data analysis of survey data. Second, depending on who in the land reform process is giving the interview (e.g., Dalit farmers, government officials of various stripes, or Navsarjan

\footnotetext{
${ }^{1}$ While I will use the words "redistribute" and "redistribution" to refer to any government-mandated act that has the effect of transferring land to or from a specified demographic group, Indian officials in with the Indian Administrative Service use these words only in reference to a government-mandated act that has the effect of transferring lands from one private holder to another. Therefore, the Government Lands Programme, which distributes idle government lands to poor would-be farmers (as discussed in Section 2) is not officially termed "redistribution." The advantage of my definition lies mainly in the fact that government lands prior to redistribution are oftentimes unofficially in use, either as illicitly cultivated plots or as village commons. $27.6 \%$ of allotted government lands surveyed are still partially or entirely
} 
activist fieldworkers), there are contradictory accounts of the relative importance of government facilitation, type of land redistributed, local social pressures, and Dalit "mindsets" in successful Dalit land cultivation. A quantitative analysis may go some way toward parsing the relative weight of each factor, allowing me to hold constant confounding variables. Third, because Navsarjan relies on the meticulous and quantitative cataloguing of government failures in the land reform process, following a similar strategy may prove revelatory of Navsarjan's own agenda in defining government's obligations toward civil society and the definitional composition of that civil society. Ultimately, then, this study will attempt to transcend the reliance on quantitative data, bearing in mind that Navsarjan's relentless documentation of the worst cases skews its view and its portrayal of the rural Dalit plight, as well as the government's moral responsibility for addressing it.

In Section 3, I examine Navsarjan's tactics in the land redistribution movement. I argue that the organization's success is largely due to its instinctive understanding of the nested game being played in the government hierarchy. I then examine qualitative evidence that could complement (and point up shortcomings of) Section 2's quantitative analysis. I conclude by examining avenues for future research and making policy recommendations for Navsarjan and for the state.

Information Sources. Section 1 is entirely based on information available in the public domain (aside from some observations on the philosophy of the Navsarjan Trust in movement, the socioeconomic impact of the two types of land reform may be similar or even identical. 
Subsection 1.4.4). For my exposition on local government officials' responsibilities and relationships in Section 2.1, I rely primarily on interviews with officials in Surendranagar district and Navsarjan fieldworkers who have experience navigating the bureaucracy, as well as focus group discussions with Dalits who applied for redistributable lands. I administered these interviews and focus groups discussions in July of 2006 and January of 2007. The quantitative analysis of land reform implementation in Subsection 2.2 relies primarily on the second of two Navsarjan-administered surveys (administered in 1996 and 2006 respectively) discussed below.

Navsarjan administered two surveys to Dalit recipients of redistributed land. The first survey was written by Navsarjan and administered in various talukas and districts of peninsular Saurashtra in $1995-1996^{2}$, with special emphasis on four talukas of Surendranagar district that became the touchstone for Navsarjan's later Public Interest Litigation (PIL) in the Gujarat High Court (discussed in Subection 1.3.3). These talukas were namely: Lakhtar, Limbdi, Sayla, and Vadhwan. They constitute the first areas in which Navsarjan field staff began working with local Dalits, informing them of their legal rights under the land codes, and whistleblowing in those cases where their rights were infringed. Navsarjan included the survey results in tabular form in a self-published document entitled "The Story of Land Reforms in Gujarat" (Navsarjan 2000a).

The second survey was written in July of 2006 by the Navsarjan's Land Redistribution Programme fieldworkers, in consultation with me. It focused on only the four previously- 
mentioned talukas of Surendranagar district. This survey's intended function was to assess the impact of the High Court's ruling of 1999, which mandated local governments to expedite the handover of lands officially redistributed to Dalits, but to whom actual possession was, in reality, denied (see Subection 1.3.3). The second survey was administered over a period of four months, from August to December $2006^{3}$. In order to be able to hold as many variables constant as possible when analyzing government's relationship to the efficacy of land redistribution, I have also appended via cross-reference two separate data sources: (1) the India Census 2001, and (2) the state's Below Poverty Line listing for Surendranagar district. ${ }^{4}$

Both surveys focused on talukas that Navsarjan staff deemed to pose particular problems for Dalit land recipients. In 1995, Martin Macwan, founder of Navsarjan, obtained land records from individual Mamlatdar offices in the nine Surendranagar talukas. For their first survey, Navsarjan fieldworkers chose talukas based on the number of cited land disputes. The intense clustering of tenure problems in the chosen talukas may more vividly evoke qualitative descriptions of problems associated with obstacles to Dalit cultivation than more progressive talukas (where such problems might be subtler in form, or even nonexistent). However, the data obtained from such a biased sample cannot be used statistically to infer the incidence of land tenure problems for Dalits in other districts, or even in other talukas of Surendranagar district. In order to render the surveys

\footnotetext{
${ }^{2}$ These talukas and districts included: Degham taluka in Gandhinagar district, Harij taluka in Patan district, Jasdan taluka in Rajkot district, Sami taluka in Patan district, Vallabhipur taluka in Bhavnagar district, and Viramgam taluka in Ahmedabad district.

${ }^{3} \mathrm{~N}=721$, where the unit of analysis is the household. All Dalit land recipients were interviewed in each surveyed village, and 129 villages were surveyed.
} 
comparable to one another, the same talukas were targeted in the 2006 survey as in that of 1995. However, irregularities in the 1995 data made time-elapse data analysis impossible. Therefore, when I compare the 1995 and 2006 surveys in Subsection 2.4, the talukas do not match.

Throughout quantitative analysis, it should be borne in mind that Navsarjan, as an activist organization, has a clear agenda. That agenda, as is discussed further in Subsection 1.4, is based on the proposition that land ownership for Dalits is an unmitigated social good. The survey enumerators are also well-known in the communities they covered, and often serve as Dalit cultivators' most direct line of communication to local government officials. This fact may be at once considered beneficial and a drawback in survey enumeration. On the one hand, many Dalit farmers are leery of speaking with outsiders about land issues for fear of retribution. Therefore, Navsarjan's long, slow accumulation of trust in hundreds of villages across the state presumably fosters a freer expression of local concerns. However, Navsarjan's enigmatic role as community organizer, agitator, and even proxy government representative, may also encourage unfounded claims to land-a suspicion confirmed by some of my field interviews.

The entirety of Section 3 is based upon qualitative information gleaned in the course of interviews, as well as on quantitative data from the preceding Section.

\footnotetext{
${ }^{4}$ For the latter, I am deeply grateful to the activist documentary film organization Drishti, and in particular Siddharth Chadha and Stalin K., as it was they who filed the application for the information with the state under the Right to Information Act.
} 


\subsection{A Brief History of Land Redistribution in Gujarat Since Independence}

The history of legal reform in Gujarat is Janus-faced: the state is both famed for its progressive land policies, and notorious for its recalcitrance (Navsarjan 2000a). This bifurcated reputation stems primarily from two politico-historical facts. The first is not be taken up in this thesis, but nonetheless deserves mention: the administrative territory of the present state of Gujarat forms a composite of two former territories with disparate administrative legacies. (This history is briefly summed up in Section 1.3.1.) The second politico-historical fact is at the core of this thesis's focus: Gujarat has a history of introducing progressive legislation at the state level that is not efficaciously carried out on the ground.

\subsubsection{The Administration of Post-Independence Gujarat}

On 23 January 1948, the Kathiawar rulers approved the creation of Saurastra province (footnoted in Gandhi 1995), embracing 217 separate princely states in Saurashtra and Kathiawar. Then in 1957, Saurashtra province in its entirety was appended to what was now called the Greater Bombay State. Finally in 1960, in accordance with a muchdebated national policy of state reorganization along linguistic lines ${ }^{5}$, the state of Bombay was split into the present-day states of Maharashtra and Gujarat (Shah, in Omvedt 1982). To complicate things further, certain districts in Gujarat had been, in colonial times, formally administered by the British, while the vast majority of the districts now making

\footnotetext{
${ }^{5}$ The India National Congress party had long supported the policy of linguistically-determined administrative boundaries. However, the party leader and first Prime Minister of India, Jawaharlal Nehru, was gravely concerned that the idea of linguistic determination that had fueled his party's popular success might also lead to an India too riven by language groups to function collectively. After serving on the Linguistic Committee, Nehru ruefully recalled:
} 
up Gujarat (including all of those in Saurashtra) were administered by so-called "Native states" (Iyer 1997).

Some of the ablest men in the country came before us and confidently and emphatically stated that language in this country stood for and represented culture, race, history, individuality, and finally a subnation. (Cited in Geertz 1973, 256) 


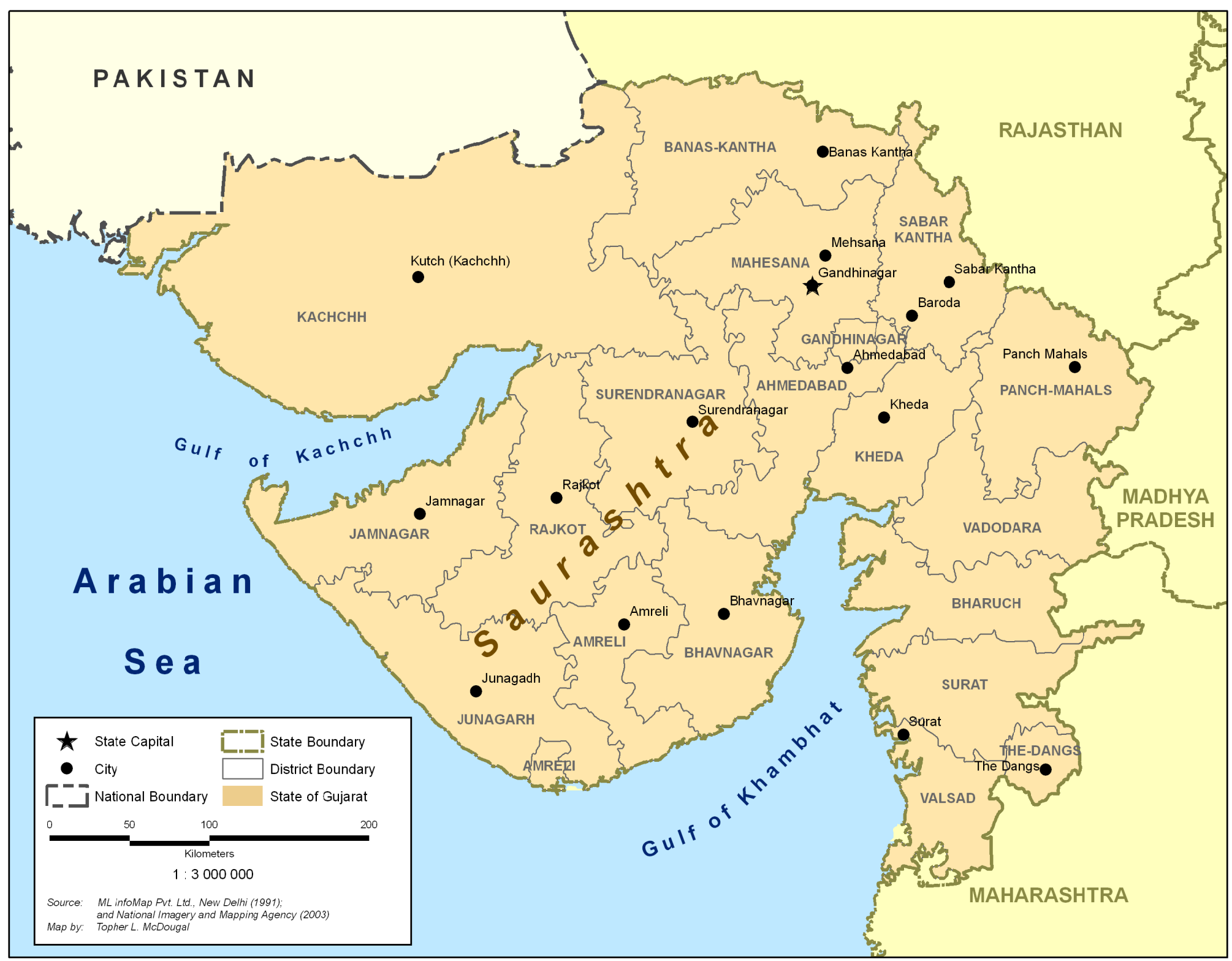

Figure 1.3.1-1. Map of present-day Gujarat and its administrative districts. 


\subsubsection{Gujarati Land Reform Legislation}

Three principal pieces of legislation shape the process of land redistribution: the Land Tenancy Act (1948), the Land Ceiling Act (1960), and the Government Lands Programme. The first has been mostly ineffectual and its consequences have largely already played out. Consequently, Government officials under pressure to redistribute lands to the Dalit community usually choose to redistribute either "surplus" lands (also called "ceiling lands") declared under the Agricultural Land Ceiling Act, or "government wastelands" as specified under the Government Lands Programme.

The Land Tenancy Act (1948). The Land Tenancy Act of 1948 constitutes the first post-independence national land act. For both British-administered and native territories, Indian independence legislation meant the end of the zamindari system. Under this system, absentee feudal landlords, or zamindars, collected revenues for the Mughal and British governments from renters. The latter in turn used employed and bonded labor to cultivate the fields. And while independence saw a large devolution of land rights from zamindars to upper- and middle-caste renters, these reforms did not reach the lowercastes, whose members actually tilled the land (Mearns and Sinha 1999). Ironically, the post-independence reforms actually encouraged the middle-caste recipients of land to kick agricultural laborers off their land in order to reduce their legal claim to it (Chakravarti, in Mohanty 2004). Chakravarti claims that the middle- and upper-castes were able to prevent any further devolution of land rights because (1) the upper-castes held sway over reform administrators, and (2) the forward castes were able via social pressure to repress members of the lower-castes who attempted to organize against them (ibid.). Furthermore, the 26 amendments tacked on to the legislation at various times 
generated a fair amount of confusion among would-be beneficiaries, and of the 2.5 million acres originally foreseen changing hands, only around 1.2 million ever did so (Navsarjan 2000a).

The Land Tenancy Act granted all land tenants the right to purchase the land they cultivated from the current landlords (though only around 2\% did so). The 1957 amendment to the act simply banned the practice of land tenancy (i.e., sharecropping) outright. This ban effectively forced tenants to buy or quit the land, but its simplicity proved impractical and often served to nullify existing claims that could not be readily substantiated or paid for (Chakravarti, in Mohanty 2004; Navsarjan 2000a). The net effect was that 'surplus' landholdings belonging to Brahmans and other upper castes devolved principally to middle-castes, but not to lower castes and Dalits. In Gujarat, this process led to the economic dominance of the Patels that continues to this day (Navsarjan 2000a).

The Agricultural Land Ceiling Act (1960). The 1960 Gujarat Agricultural Land Ceiling Act figures prominently among Gujarat's progressive land measures. The Act fixed the maximum land area tenable by a single owner in a rural sector at 132 acres (later reduced to 54 acres in the 1976 amendment) (Jindal 1985) and dictated that the surplus be allotted to Dalits (outcastes), tribal peoples, and Other Backward Castes (OBCs). The Act came early in a period defined by similar legislation passing in various other states (Srivastava 2006). It was designed to further devolve land ownership to the lower castes whom the Land Tenancy Act had largely failed to reach. In combination with the 
Government Lands Programme (see below), the state Agricultural Land Ceiling Acts have—at least on paper—generally worked to some degree (see, e.g., APPENDIX A).

If the ALCAs have bolstered inter-caste land ownership equity, however, they have seemingly also lessened intra-caste land equity. Table 1.3.2-1 displays the percentage of landholdings of vulnerable demographics by size category in India as a whole in 1982 and again in 1992. The trend clearly emerges of larger numbers of smaller holdings. When this data is used to derive Lorenz curves (see Figure 1.3.2-1), ${ }^{6}$ two interesting findings present themselves. First, the degree of inequality is systematically higher among Dalits than among Scheduled Tribes, and is again higher among Scheduled Tribes than among OBCs. Second, during the period in question, even as inter-caste equality of land assets was presumably on the rise, intra-caste equality of land assets seems to have been on the decline. This trend presents itself in the downward shift in the Lorenz curves for each of the three demographic classes of marginalized populations over the decade 1982-1992. While other exogenous variables may very well be at work, ${ }^{7}$ it should be noted that this trend may plausibly be explained by postulating a large number of marginal and small landholders entering the picture who were not previously taken into account. Many parcel recipients were previously landless agricultural laborers (Srivastava 2006), and

\footnotetext{
${ }^{6}$ A Lorenz curve is a graphical representation of population inequality using cumulative distribution functions. Perfect equality (all members of a group with equal shares of the variable in question) is represented by the $45^{\circ}$ line, while perfect inequality (all of the variable in question concentrated in the hands of a single person) is represented by the X-axis and the vertical edge of the graph at the $100 \%$ mark. The Gini Coefficient of inequality is a ratio of (1) the area between the line of perfect equality and the observed curve, and (2) the total area between the line of perfect equality and that of perfect inequality. To approximate asset levels for the present exercise, I have assumed for simplicity that marginal plots are 0.5 hectares, small plots 1.5 hectares, medium plots 3 hectares, and large plots 4 hectares.

${ }^{7}$ In addition to changes in land tenure relations, Jayaraman and Lanjouw (1998) note agricultural intensification and occupational diversification as forces at work in socioeconomic stratification at the village level.
} 
with the all-India average size of awarded plots at around 1 acre (see Table 1.3.2-1), the relative size of the marginal and small class of landowners swells. That said, the rise of intra-caste inequality may be unavoidable in a society transforming itself from a ranked to an unranked socioeconomic hierarchy, as each social stratum coincides less well with economic status (see Section 1.4) and begins to take on the income distribution of the society as a whole.

Table 1.3.2-1. Percentage distribution of ownership holdings among vulnerable populations.

\begin{tabular}{lrrrrrr} 
& \multicolumn{2}{c}{ Scheduled Castes } & \multicolumn{2}{c}{ Scheduled Tribes } & \multicolumn{2}{c}{ Others (OBCs) } \\
\cline { 2 - 7 } Size Class & $\mathbf{1 9 8 2}$ & $\mathbf{1 9 9 2}$ & $\mathbf{1 9 8 2}$ & $\mathbf{1 9 9 2}$ & $\mathbf{1 9 8 2}$ & $\mathbf{1 9 9 2}$ \\
\hline Marginal (less than 1 ha.) & 26.6 & 30.2 & 12.0 & 18.7 & 10.9 & 14.9 \\
Small (1 to 2 ha.) & 22.71 & 22.2 & 18.8 & 22.7 & 15.6 & 17.5 \\
Medium (2 to 4 ha.) & 24.0 & 20.4 & 29.2 & 27.7 & 22.6 & 24.7 \\
Large (above 4 ha.) & 26.8 & 27.2 & 40.0 & 30.9 & 50.9 & 42.9 \\
Total & 100.0 & 100.0 & 100.0 & 100.0 & 100.0 & 100.0 \\
Source: NSS, Land Holding Survey 37th round No. 330 1982 \& 48th round No. 399 1992, Central Statistical \\
Organisation, Delhi.
\end{tabular}




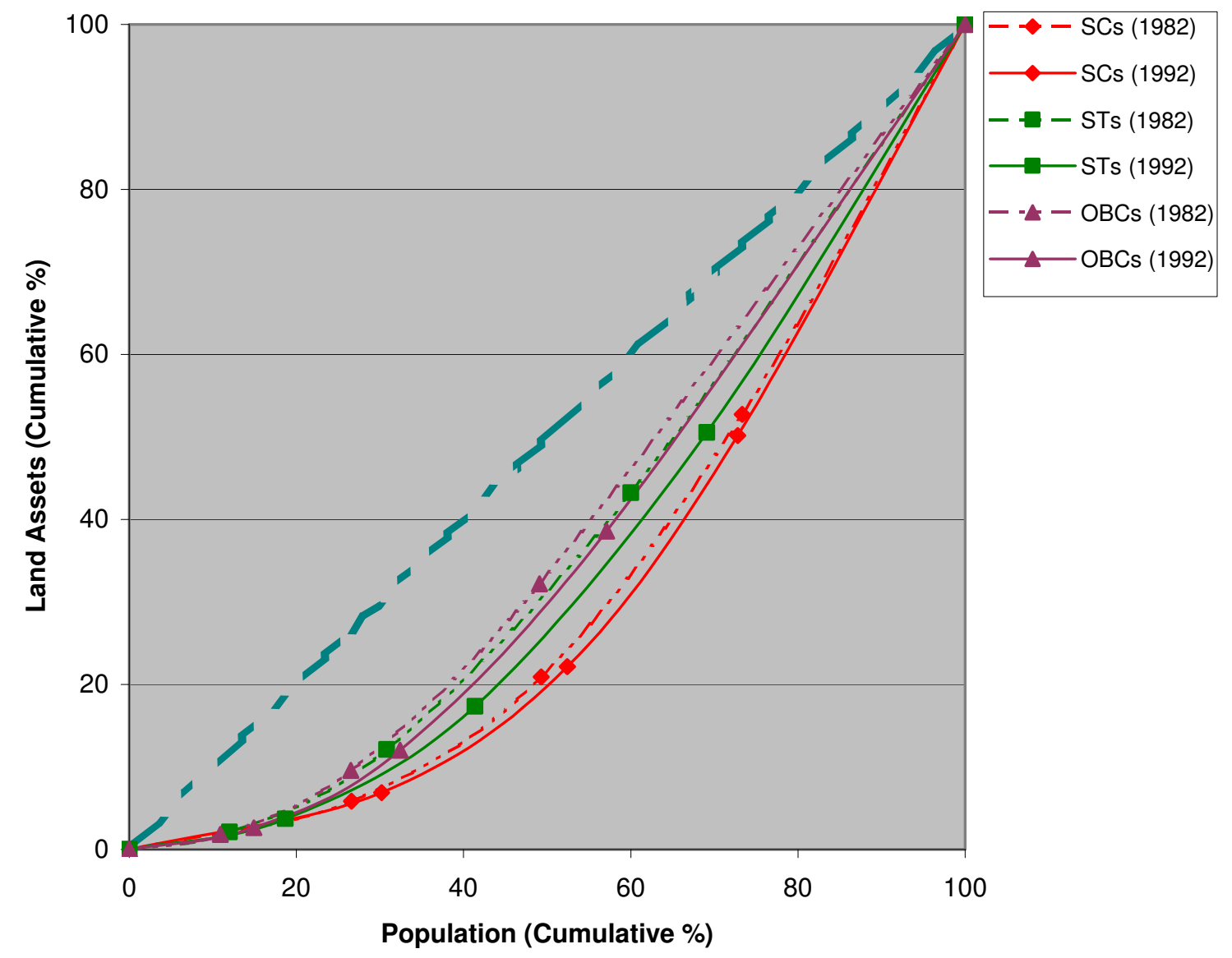

Figure 1.3.2-1. Lorenz curves of land asset ownership among vulnerable populations in India (19821992).

Source: NSS, Land Holding Survey 37th round No. 3301982 \& 48th round No. 399 1992, Central Statistical Organisation, Delhi. Derivations and graph by the author.

To be redistributed under the ALCA, lands must first be declared surplus and then navigate a complex bureaucratic system that greatly reduces their chances of successful cultivation. This thesis deals in some detail with the bureaucratic system, but does not address (for lack of reliable information) the question of a parcel's original declaration as surplus. Only 101,700 acres of the 1.35 million acres originally estimated as eligible for redistribution in Gujarat (or 7.5\%) were in fact declared surplus as of 2000 (Navsarjan 2000a). As paltry a sum as this might seem, it is about three times better than the record 
for India as a whole: about 750,000 acres declared surplus in India out of an original 30 million estimated (or 2.5\%) (National Campaign on Dalit Human Rights 1995).

The Government Lands Programme. This state government land-leasing program authorizes local governments to allot so-called government wastelands to those willing to improve them and bring them under cultivation. It is officially authorized under Chapter $\mathrm{V}$ of the ALCA (Jindal 1985), but functions differently from its cousin. The lengths of the lease vary from a renewable 1-year contract (prevalent in southern Gujarat) to 99-year terms. The terms in Saurashtra, where Surendranagar district is located, are of the longer variety, and so function in effect like fee simple ownership.

In Gujarat, the scale of this program has far outstripped that of the ALCA, for reasons elaborated below in Subsection 1.3.4. For instance, in the southern sub-district of Surendranagar comprised of the Chotila, Limbdi, Muli, and Sayla talukas, 64,313 acres of government lands have been distributed since 1960 (see Table 1.3.2-2 and Table 1.3.2-3). That same sub-district, according to its Deputy Collector, has only distributed 5,563 acres of lands under the ALCA. For now, suffice it to state over-simplistically that the allotment of state leaseholds is obviously less politically contentious than the systematic stripping of private property from powerful upper-caste members, as well as being less permanent. Nevertheless, as with ALCA lands, official documents overstate the success of redistribution on the ground. 
Table 1.3.2-2. Government lands in the southern sub-district of Surendranagar district distributed from 1960 to December 2006, categorized by recipient caste.

\begin{tabular}{lrrr} 
& \multicolumn{3}{c}{ Distribution by Caste } \\
\cline { 2 - 5 } \multicolumn{1}{c}{ Caste } & Area (Ac.) & Recipients & Average Area \\
\hline (i) Scheduled castes & 24,564 & 3,285 & 7.5 \\
(ii) Scheduled tribes & 3,618 & 726 & 5.0 \\
(iii) Other beneficiaries & 36,131 & 5,663 & 6.4 \\
(iv) Societies/institutions & 4,983 & 4 & 1245.8 \\
\hline Total & $\mathbf{6 4 , 3 1 3}$ & $\mathbf{9 , 6 7 4}$ & - \\
\hline
\end{tabular}

Source: Surendranagar District Land Records Office.

Table 1.3.2-3. Government lands in the southern sub-district of Surendranagar district distributed since 1960, categorized by taluka.

\begin{tabular}{|c|c|c|}
\hline \multirow[b]{2}{*}{ Taluka } & \multicolumn{2}{|c|}{ Distribution by Taluka } \\
\hline & Area (Ac.) & Recipients \\
\hline Chotila & 17,529 & 23 \\
\hline Limbdi & 17,627 & 0 \\
\hline Muli & 16,404 & 17 \\
\hline Sayla & 12,752 & 0 \\
\hline Total & 64,312 & 40 \\
\hline
\end{tabular}

Source: Surendranagar District Land Records Office.

\subsubsection{Navsarjan's Public Interest Litigation}

As of 1997, approximately 50,000 acres of unused government "wastelands" were allotted to landless Dalits. In 1995-6, the Navsarjan Trust ${ }^{8}$ administered a survey describing the status of government-declared surplus lands, including the nominal area, area in Dalit possession, natures of possible encroachment, and the availability of legal documentation of land title. In April 1999, the organization galvanized the local Dalit communities in four talukas of Surendranagar district in Saurashtra (namely, Sayla, Vadhwan, Limbdi, and Lakhtar), to file a PIL (Public Interest Litigation) in the Gujarat High Court against the state, the State Secretary of the Revenue Department, the Special

\footnotetext{
${ }^{8}$ It is interesting that the group elected to register itself as a "trust" rather than a private NGO. This fact may reflect the desire to be more than "just an organization," but rather the legal manifestation of a larger social movement that welcomes-indeed requires—Dalit stakeholders to buy into the Navsarjan project.
} 
Secretary of Revenue for the Appeals Department, and the District Collector of Surendranagar District. In the PIL, Navsarjan documented over 6,000 acres of lands in Surendranagar district that had been officially allotted to 700 Dalit families according to the District Collector's office, but which the 1995 survey had found to be either unaccompanied by the necessary documentation for recipients to prove title, or not actually in the hands of the intended beneficiaries. The Court ruled that the state must complete its survey and distribution of the surplus lands by 15 June 2000. Navsarjan has long suspected that even the Court's ruling went largely unheeded. The group recently completed a follow-up survey I helped to design to obtain a time-elapse portrait of the status of land-holdings in the wake of the ruling.

\subsubsection{A Comparative View of the ALCA and Government Lands Program}

How does Gujarat compare to other Indian states in its land redistribution efforts? Within Gujarat, how do the two land redistribution programs compare with one another? I address these two questions in order. APPENDIX A describes the extent to which participating Indian states have implemented land reforms (as of 1996-the year of Navsarjan's first land survey), with special consideration for scheduled caste recipients. Here I adapt a simple technique called location quotient (LQ) analysis from regional economics (see, e.g., Heilburn 1981, 153-169), and define it in this context as the degree to which land redistribution has taken place in Gujarat versus India has a whole. We may state that Gujarat's location quotient is: 
$\mathrm{LQ}=\left(\mathrm{r}_{\mathrm{g}} / \mathrm{p}_{\mathrm{g}}\right) /\left(\mathrm{r}_{\mathrm{i}} / \mathrm{p}_{\mathrm{i}}\right)$, where:

$r_{g}=$ redistribution effected in Gujarat (measured either for the class of total redistributions or for Dalits, with units in either acres or beneficiaries) $\mathrm{p}_{\mathrm{g}}=$ population of Gujarat (either Dalit or total) ${ }^{9}$

$\mathrm{r}_{\mathrm{i}}=$ redistribution effected in all India

$\mathrm{p}_{\mathrm{i}}=$ population of India

A location quotient of 1 in this case would indicate that the redistribution measures undertaken in Gujarat are perfectly commensurate with those undertaken in India as a whole. A location quotient less than 1 would indicate sub-par performance, and a location quotient above 1 would indicate superior performance. The same exercise can be performed on the average parcel size allotted (see results in Table 1.3.4-1).

Using this method of data interpretation, Gujarat generally ranks poorly against its state competitors. Gujarat has been just over half as effective as India as a whole in terms of per capita acres distributed, and is only $1 / 8$ as effective as other states in terms of per capita beneficiaries reached. The programs seem to fare better when specifically targeting Dalits. Gujarat's redistribution efforts are roughly twice as effective than other states in terms of acres distributed, but only around $1 / 4$ as effective in terms of sheer numbers of program beneficiaries. The discrepancy in both cases between acreage-based and beneficiary-based location quotients is probably due to the arid environment in Gujarat: it simply takes more land to sustain a beneficiary family in Gujarat than in most other states, as indicated by the location quotients of 4.4 and 5.4 respectively assessing 
average parcel size of redistributed lands to beneficiaries generally and Dalits in particular. The neighboring desert state of Rajasthan has similar (even slightly higher) parcel size location quotients. With this in mind, we can postulate that the beneficiarybased location quotients are more reliable (i.e., less inflated) than the acreage-based ones, and conclude that Gujarat has a substantially sub-par record at land redistribution, even judged with the built-in bias that not all states in India participate at all in such programs. The latter point is a double-edged sword however: the state of Gujarat should also be recognized for passing the legislation in the first place.

Table 1.3.4-1. Location Quotients for Gujarat's redistribution measures sorted by acres, number of beneficiaries, and average parcel size.

\begin{tabular}{lcr} 
& \multicolumn{2}{c}{ Beneficiary Categories } \\
\cline { 2 - 3 } Location Coefficient Type & All Recipients & Scheduled Castes \\
\hline Acres Redistributed & 0.53 & 2.08 \\
Number of Beneficiaries & 0.13 & 0.28 \\
Average Parcel Size & 4.44 & 5.36 \\
\hline
\end{tabular}

Source: Surendranagar District Land Records Office, Report of the National Commission for SCs/STs, 1995-1996, extracted in Thorat, Social Security for SCs in unorganized sector in S.M. Dev \& others, Social and Economic Security in India, 2001, p. 371 Delhi, and author's calculations.

Program Commonalities. At the state level, the two redistribution programs share some commonalities. For one, they are often both lumped together in official parlance as "land reforms." They jointly constitute the policy workhorses of the land redistribution push. Furthermore, both programs have been embraced, to varying degrees, by a number of other Indian states.

\footnotetext{
${ }^{9}$ For this exercise, I used the old 1991 India Census population data, as it aligned better chronologically with the Report of the National Commission for SCs/STs, 1995-1996.
} 
The two sets of land reforms also share more mundane, technical features. Redistributed parcels, for instance, must be at least 2 acres in area. Additionally, title is conditional on putting the land to beneficial use. If the Talati (local village revenue officer) notes that the land lies fallow for three consecutive years, the government has the right to reclaim the parcel and re-redistribute it. Once title is awarded, the recipient is legally interdicted from selling the land for a period of 15 years, during which time the parcel is said to be under "new tenure." After the time limit has elapsed, title falls under "old tenure" rules and may then be sold (Jidhal 1982).

Implementation of both land schemes also poses formidable obstacles to Dalits trying to take possession of their allotted parcels, to be elaborated in detail in Subsection 2.3. Much of the land is encroached upon by non-Dalits, oftentimes the original owners who refuse to quit it, in the case of ALCA lands. In addition, many parcels do not obtain the necessary bureaucratic certifications (e.g., survey and land ledgers), are caught in litigation, have no access easements, or are effectively off-limits to Dalit owners due to implicit or explicit threats of violence, social ostracism, or economic boycott.

Program Differences. While not originally envisaged as a substitute for redistributed “ceiling lands," government lands have been used as such so as not to anger powerful local landholders (Pradip 2007, Pers. Comm., Srivastava 2006). This tactic has gained currency now in a number of other states, as well (Srivastava 2006). It should be noted, however, that to the extent that government lands do substitute for ALCA lands, the substitution is one facilitated by the institutional dynamics of local governments operating in an ethnically divided society. It should not be mistaken for a conscious choice on the 
part of a few nefarious officials. Indeed, as is discussed in Subsection 2.1, the selection process for identifying lands to be redistributed is not carried out by the same officials under the two programs. Therefore, the relative paucity of ALCA lands declared under the ALCA may simply have shifted the burden for redistribution to the government lands program.

The substitution is broadly considered an unfavorable one. Many Dalits interviewed for this study asserted that the intensive improvement investments that government lands require deter them from cultivating. A simple cross-tabulation of the 1996 survey data would prima facie corroborate this contention: while $7 \%$ of government lands parcels were reported to be uncultivable, no ALCA were reported to be so. ${ }^{10}$ The 2006 survey finds that only $50.0 \%$ of ALCA parcels and $60.4 \%$ of government parcels redistributed to Dalits are currently under cultivation. ${ }^{11}$ However, the 2006 survey did not ask about cultivability per se, but rather the actual act of cultivation. The very cultivability of a parcel of ALCA lands exerts a draw on powerful upper-caste encroachers. ${ }^{12}$ Even if new farmers do manage to collect the necessary funds to bring the land under cultivation and eject the encroachers, though, Navsarjan fieldworkers consider the substitution of relatively low-quality wastelands for ceiling lands to lessen the likelihood that Dalits will be able to cultivate the land far into the future. They claim lower profits from less fertile land causes Dalit farmers to sell off or be intimidated off their lands sooner than they might have with better lands. Certainly, the 2006 survey indicates that ALCA parcels are

\footnotetext{
${ }^{10}$ This difference is significant using a Chi-Square test at the $90 \%$ confidence level. The small 1996 survey sample size depresses the confidence levels for data derived therefrom.

${ }^{11}$ This difference is significant using a Chi-Square test at the 99\% confidence level.
} 
typically worth more than their government wasteland counterparts (the respective means were INR 250,000 and INR 185,000).

While the government lands program provokes less opposition than the Agricultural Land Ceiling Act, it is not without controversy. For instance, many of the government lands are used as village commons, and so successful transfers constitute privatization (Srivastava 2006). If the intended recipients sell off their lands to wealthier upper-caste members, the net result will be privatization of government lands and village commons into the hands of the socioeconomic elite-completely counter to the stated ambitions of the land reform legislation.

\subsection{Theoretical Models for Assessing Land Redistribution Initiatives}

At this point, it is necessary to present Navsarjan's goals and how their strategy aims to accomplish them. Without such an understanding, there will be no criteria by which to judge Navsarjan's progress or success. In order to do this, however, it is first necessary to build a theoretical model that adequately but simply describes the caste system's function, as well as the strategies that Dalit activists might reasonably choose to espouse in their fight against it.

The following section discusses, in turn, Horowitz's dichotomy of ranked and unranked societies as a theoretical lens through which I view caste conflict (1.4.1); a compressed

\footnotetext{
${ }^{12}$ A dummy variable indicating the type of land distributed explains by itself $27 \%$ of the variation in the success rate of removing upper-caste encroachments. New owners of ALCA lands are $16.5 \%$ more likely to be accompanied by a stubborn encroacher (this result is significant at the $99 \%$ confidence level).
} 
history of the caste system itself (1.4.2); the Dalit struggle for civil rights since Indian Independence (1.4.3); and Navsarjan's place within the larger Dalit struggle (1.4.4).

\subsubsection{Ranked and Unranked Societies}

I structure my interpretation of Dalit activist goals in reference to Donald Horowitz's concept of ranked and unranked societies. Horowitz defines the term 'ethnic conflict' as any conflict based on ascriptive group identities, such as tribe, race, language, or caste (Horowitz 2000). He contends that in a society characterized by ethnic cleavages, those cleavages may run "horizontally," thereby dividing society into hierarchical stratifications, or "vertically," thereby dividing society into side-by-side, stand-alone pillars.

Ranked societies exhibit coinciding social classes and ethnicities, whereas unranked societies exhibit no coincidence between social class and ethnicity. Ranked societies' constituent layers are necessarily in constant friction with one another, as the upper layers weigh on the lower layers. The lower layers in a stratified agrarian society will not likely be independently politically represented, but rather will share leaders with the strata above them (Gellner 1983). When lower strata do have political leaders, Horowitz (2000) suggests that they must ultimately satisfy the criterion of acceptability to superordinate groups. Horowitz further contends that for oppressed strata in a ranked society, there are a finite number of strategies for redress:

1) displace one's superiors,

2) dissolve ethnic distinctions between strata completely,

3) raise one's position objectively, 
4) attempt to transform the society into an unranked system.

The Indian caste system is most certainly a case of a ranked society. It represents a hereditary hierarchy that dictates acceptable occupations, marriage partners, public behavior, social standing, and home location. It is important to distinguish between the religious beliefs that ground the caste system ideologically, and the social and institutional norms that perpetuate or challenge it in practice.

In religious or ideological terms, the system is broken down by Varna (broad caste groupings) that include, in descending order of purity, Brahman (scholars, teachers and priests), Kshtriya (kings, vassals and warriors), Vaishya (merchants, traders, and retailers), and Sudra (agriculturalists and farmers) (National Human Rights Commission 2004). The Varna are said to correspond to the various parts of the body of the divinity Brahma, from which they are derived. Thus, Brahmans were made from the head, Kshtriya from the arms, Vaishya from the torso, and Sudra from the legs. Outside of the Varna system, but nonetheless ranked lower than all Varna in social practice, are the Dalits (also known as Parjanya, Harijans, Antyaja, "untouchables," “outcastes,” and, in legal terms, "Scheduled Castes" in reference to the fact that they do not belong to a Varna caste, but are rather included in the Fifth Schedule of the Indian Constitution). The term 'Dalits' as used in Gujarat encompasses three major subgroups, or jati (again listed in descending order of purity): the Weavers (Vankar), the Leatherworkers (Chamar), and the Scavengers (Bhangi) (ibid.). 
Jati, or sub-castes, play an equally, if not more, important role in the social life of Indians. Jati are theoretically supposed to belong to a specific Varna, though a number of jati are disputed in their Varna affiliations. Furthermore, while the Varna are grouped so as to reflect a divine cosmic order (and are thus immutable), the status of jati may more directly reflect their common social and economic standing in a particular community. Thus, jati may be somewhat socioeconomically mobile within their particular Varna, but not across Varna divisions. An example of this in the Gujarati context is provided by the Leatherworker, or Chamar, subcaste, whose primary occupation was taken over by the higher-ranking Patel sub-caste upon the mechanization of leather processing (which rendered the task less impure and more acceptable to higher castes). An MIT research project's survey in the village of Paliyad, Gujarat, found that discrimination against the Leatherworkers in all recorded dimensions (government institutions, marketplace, social or cultural events) had anomalously dropped to below the level of discrimination endured by the Weavers (Rajagopal et al. 2006). While this phenomenon is presumably the result of their expulsion from leatherworking, it bears noting that Leatherworkers lost their only caste-condoned occupations, and may no longer come into as frequent contact with upper-castes if they are unemployed.

Finally, the ethnic "friction" referred to above, while not religiously sanctioned, has embedded itself intractably in the fabric of Indian society. This friction takes the forms of discrimination in government institutions, the marketplace, and sociocultural events; routine acts of rape and violence; and, in even more extreme cases, atrocities committed against Dalits (see, e.g., Sikand 2005, Devi 2000, National Campaign on Dalit Human Rights 1995). It serves to perpetuate the social hierarchy by way of general degradation 
of human dignity, social humiliation, and punitive measures against those who transgress caste-based norms (Fernandes 1996, Narula 1998, National Human Rights Commission 2004, Rajagopal et al. 2006).

\subsubsection{The Caste System}

Klass (1980) hypothesizes that the subcontinent's heterogeneous mix of ecological zones was particularly conducive to differentiated methods of food production, and resource extraction. He contends that the various tribal groups can be considered proto-jatis (proto-castes) which, as agricultural surplus developed and increased, were gradually rearranged in a hierarchical system. Tribal "closure," or cohesiveness, may have partly been a countervailing response to the numerous large-scale states spanning many ecological zones. If Klass is correct, then the establishment of the caste system equates to the "horizonalization" of what had essentially been, in Horowitz's terminology, a vertically cleaved society whose pillars had been linked primarily geographically through trade.

Omvedt (1994), advocating for a particularistic explanation of this unique phenomenon, suggests the highly differentiated Dravidian society, having already developed a notion of social purity and pollution in the time of the Indus civilization, was susceptible to the introduction of an exaggerated version of the purity-pollution gradient by Aryan inmigrants. Following the inception of the nascent caste system, Omvedt describes a millennial period of ascendancy for the Indo-Europeans, characterized by increasingly hardened caste roles. This period was in turn followed around the middle of the first millennium BCE by the rise of the Magadha-Mauryan states and a period of religious 
contention during which Buddhism challenged Brahmanical Hinduism for dominance on the subcontinent. This period saw the decline of caste society in mleccha, or antiBrahman, territories.

A Hindu counter-revolution between 600-900 CE re-launched caste society's supremacy and a feudal period in which the jajmani system mediated production relations between landowning (primarily Kshtriya) and landless castes in pre-monetary village economies. Despite claims that the jajmani system rendered villages essentially self-sufficient, Omvedt (1994) describes this feudal system as one in which localities linked agricultural production across ecological niches. The system also gave rise to some divergences between Varna (socio-religious status) and jati (production class), as the Kshtriya, socially inferior to the Brahmans, became economically dominant as landowners. Even so, Omvedt (1994) points out that agricultural surplus was divided into a melvaram ('upper share') and kilvaram ('lower share'), the former of which was frequently assigned to Brahmans. Furthermore, arid regions that generated little surplus exhibited less caste inequality than did rich, irrigated lands generating generous surplus (ibid.).

\subsubsection{Today's Dalit Struggle}

Myron Weiner (2001) notes that over a century of socio-political activism in India has seriously diminished the political and intellectual acceptability of publicly espousing caste-based ideology to preserve one's standing. The social reality has lagged markedly behind, however, especially in rural areas. Occupational mobility is still highly tied to social status (Wankhede 1999). Upon its independence, India was sold on democratic institutions as a means of dissipating these primordial divisions and raising the economic 
well-being of all. Instead, Kothari notes that this promise has largely failed: social oppression remains firmly rooted, acts of physical aggression against lower castes reinforce caste order (Kothari 1997, Narula 1999, Pradip 2006), political power has remained in the hands of the upper castes, and economic disparities are growing. Kothari chocks this up to (1) the democratic project not being faithfully carried through, and (2) the overwhelming complexity of the Indian case proving intractable for 'traditional' democratic institutions. As a possible counterpoint to the first proposed explanation, one student of democratic reform in the developing world (Snyder 2000) argues that the very introduction of democratic processes into an ethnically riven political environment may exaggerate and deepen ethnic division.

Despite many Dalit calls to abolish the caste system entirely and dissolve caste distinctions (Horowitz's strategy 2, above; see, e.g., Ambedkar 1944), the predominant mode of Dalit activism in recent years has been to leverage the cohesive identity imposed upon Dalits (an otherwise highly heterogeneous grouping) by the system to effectuate a “verticalization" of caste cleavages (Kohli 2001, Fernandes 1996). The preservation of internal caste integrity would allow Dalits, on the bottom rung of society, to push collectively against the weight of the system above them.

The fact that Dalits have forgone Horowitz's other strategies for redress in a ranked society is entirely rational. As mentioned above, many Dalits have made calls for the dissolution of caste boundaries. This sentiment may have fueled the mass conversion of Hindus to Buddhism in 1956, led by a frustrated Dr. B. R. Ambedkar. Ambedkar, nevertheless, recognized the pervasive quality of the caste system as a social phenomenon 
that, even stripped of its religious foundations, spilled across religious boundaries to stratify even Muslim and Buddhist communities of the Indian subcontinent (Shivakeri 2004). Furthermore, the sheer intractability of a system of social categorization that has persisted, adapted, and shaped societal norms for three millennia has convinced many activists that their effort is more reasonably spent in influencing how the system operates, as opposed to destroying the system itself.

The third strategy mentioned by Horowitz for redress of the oppressed in ranked societies is that of collective betterment. That is, a caste might, through collective action, raise itself above other castes. However, as previously mentioned, the Dalits as a caste group, are ideologically bound to remain forever subordinate to the Sudra. This presents a philosophical barrier to betterment, but not necessarily a socioeconomic one. And indeed, if one considers the caste system to consist of coinciding categories for karmic position, social status, and economic potential, it must be admitted that, to a certain extent (more so in urban areas than rural ones), karmic position aligns less and less neatly with social and economic standing. However, the opportunities for economic betterment in a rural Indian village are extremely limited, as the division of labor is self-reinforcing and there is not the diversity of employment opportunities that one finds in a city. Rajagopal et al. (2006) found very little variation in income by caste, for example, but self-reported financial assets were strikingly correlated to caste hierarchy. One might attempt to explain rural Indian asset distribution by way of reference to a broad panoply of phenomena, including the institution of Dalit bonded labor, hereditary property ownership, and the impact on nominal upper-caste incomes of free labor in the form of traditional services provided by lower castes (Breman 1975). 


\subsubsection{Navsarjan's Ideology and Goals}

Sanyal (1991) has noted that many NGOs object to income generating projects on the grounds that the poorest of the poor are price-takers and therefore are often understandably unwilling to undertake comparatively risky income generation projects over a back-to-the-land approach. The Navsarjan Trust is certainly one of those NGOs. It has consciously eschewed "development" projects, contending that development can only lead to more exaggerated forms of Dalit exploitation in the absence of a radical shift towards egalitarianism in Indian society. ${ }^{13}$ Consequently, Navsarjan has focused primarily on education (informing rural Gujarati Dalits of their legal rights around issues of land and physical intimidation), bureaucratic facilitation, and legal activism (filing suits against allegedly offending governments and individuals). The latter activity is clearly geared toward bolstering Dalit solidarity. Furthermore, Navsarjan has chosen the issues it organizes around with care, concentrating particularly on land redistribution, the elimination of so-called "manual scavenging" (the designated occupation of the lowestranking Dalits, the manual removal of human excreta and dead animals from villages to urban peripheries), and technical vocational training for Dalits.

Dalit activists have for decades demonstrated a fondness for Marxist analysis. In the 1920s, a resurgence in India of Marxist historical materialism portrayed jati as the "superstructure's" manifestation of class. A second wave of Marxism swept through

\footnotetext{
${ }^{13}$ Jayaram and Lanjouw's (1998) review of 35 longitudinal studies on rural Indian poverty covering the last three decades of the $20^{\text {th }}$ century reveals that, taking rural India as a whole, little to no progress has been made in breaking down the extreme stratification of economic wealth by caste. On the contrary, they contend that economic development in rural India often went hand in hand with increased social
} 
academic literature on India during the 1970s, this time incorporating the Althusserian perspective that, in special cases (and especially in pre-industrial societies), the superstructure may dictate the development of the base (Omvedt 1994). The interest for Dalit activists is tripartite: it draws attention to the plight of the oppressed classes (or castes); it provides a mechanism for societal change over time; and it postulates a necessarily freer world in the future while casting the proletariat (or Dalits) as the righteous forerunners of the brave new world order.

The second point, that of Marxism's enabling societal change over time, is an especially critical factor for widespread Dalit and popular support. Ernest Gellner has argued that pre-industrial, 'agro-literate' societies tend to reinforce horizontal stratifications in an attempt to make them appear to be a 'natural,' immutable order:

Thanks to the relative stability of agro-literate societies, sharp separations of the population into estates or castes or millets can be established and maintained without creating intolerable frictions. On the contrary, by externalizing, making absolute and underwriting inequalities, it fortifies them and makes them palatable by endowing them with the aura of inevitability, permanence and naturalness. That which is inscribed into the nature of things and is perennial is consequently not personally, individually offensive, nor psychically intolerable. (Gellner 1983, 11)

On a similar note, Rousseau once noted that " $[\mathrm{t}]$ he nature of things does not madden us, only ill will does.” (quoted in Berlin 1969, 123) If the causes of social or economic oppression appeared natural outgrowths of an accepted cosmic order, it was unlikely that Dalits would chafe at what activists claimed were shackles. Early Indian caste activists balked at just this sort of caste 'permanence and naturalness,' and found intellectual ammunition in Marxist ideology to counter it. Ambedkar, a Dalit barrister and activist who eventually presided over the framing committee for the Indian constitution, was

stratification. They also note that the long-term poor tend to come from the lower castes dependent on agricultural incomes. 
particularly keen. In his "Annihilation of Caste" address (1944), Ambedkar stressed that (1) cultural values can be morally judged, (2) social heritage should be conserved only when it is helpful, (3) we must structure our society around the present and not the past, and, importantly, (4) nothing in this world or in our society-caste included — is fixed or eternal.

Navsarjan's focus on land redistribution reflects an attenuated Marxism inherited from early Dalit activists. Navsarjan is an avowedly "Ambedkarist" organization: his portrait graces the organization's website, hangs in the office of the director, and is reproduced (along with the likenesses of Robert Kennedy and Martin Luther King, Jr.) on a mural at Navsarjan's vocational training center, the Dalit Shakti Kendra (or Dalit Power Center) in Sanand, Gujarat ${ }^{14}$. Importantly for the purposes of this study, Ambedkar (in a parallel with the Physiocrat school of economics) accepted lands as the source of socioeconomic exploitation (Omvedt 1994). However, counter to Marx, he critically rejected the conflation of politics and economics, and therefore insisted that political conflict be seen as separate from economic development. Ambedkar's point of departure from Marx is attested to today by Navsarjan's persistent ambivalence around economic development projects, as well as their conviction that political activism can directly affect underlying economic trends.

Navsarjan's focus on land redistribution can been seen as an attempt at verticalizing horizontal ethnic cleavages. A horizontal stratum is interdependent with all other strata,

\footnotetext{
14 “Ambedkarism” is a typical ideological hallmark of many Dalit activist groups. See, e.g., Sikand 2005, on Gujarat's Council for Social Justice.
} 
and this is no less the case with the Bhangis (a sub-stratum of the Dalits), who constitute a traditionally landless community dependent upon upper-caste handouts of leftover food for their sustenance. By redistributing land, Navsarjan hopes to create a cohesive, selfsufficient community—a Horowitzian stand-alone pillar. Horowitz's conceptual framework helps us to make sense of the other activities on which Navsarjan has chosen to focus, as well. In particular, Navsarjan's vocational training program, which might otherwise be viewed as too close to an "income generation" project, can now be seen for a attempt to shake up the coincidence between ethnicity (caste) and socioeconomic status. 


\section{LAND REFORM IMPLEMENTATION}

Various levels of the Indian government jointly carry out the land reforms. Governmental subdivisions at the sub-state levels form a Weberian vertical hierarchy of three ascending tiers: village, taluka, and district. I contend that information and influence do not simply flow down from top to bottom, but also percolate up from the ground level - that the hierarchy is, in effect, contested ground. In the following subsections, I examine in turn: the official responsibilities of government offices in the land reforms (Subsection 2.1), how local government offices actually implement the land reform legislation (Subsection 2.2), the differential treatment of ALCA and government wastelands in this process (Subsection 2.3), and the social outcomes of these efforts at the household level (Subsection 2.4). In this way, the various responsibilities often vaguely attributed to "government" in vituperative newspaper exposés (see, e.g., Parimal 2005, The Hindu Online 2002, Uday 1997) can be more specifically assigned to bureaucratic organs that individually exercise discretion in their application of the law. Navsarjan (2000a) reported in 2000 that only around one-third of those lands officially redistributed on paper (or roughly 50,000 of 150,000 acres-the latter already a fractional subset of the original estimates of lands subject to the legislation) were in fact in the possession of the intended recipients. This low success rate a priori suggests two possible explanations: (1) the government bureaucracy is failing Dalit applicants in the implementation stages, or (2) social pressures exerted on the ground by upper-caste members prevent Dalits from 
claiming their rights. In fact, the two are not independent of one another. I argue below that the hierarchy of local governments is an institutional framework in which the interests of large landholders contest Dalit land claims and attempt to undermine the intended effects of progressive legislation.

\subsection{Government Officials \& Their Responsibilities}

The responsibilities of the various officials and offices are given in Table 2.1-1, and are discussed at some length in below. Officials in the first category (village/panchayat level) are elected, while officials in the latter two categories (taluka and district levels) are appointed. At the taluka level, the state government appoints local politicians and technocrats, while at the district level, the central government appoints a mix of local and out-of-state bureaucrats. Thus, the chain of command would suggest a gradient of involvement in, and alignment with, local interests. 
Table 2.1-1. Government officials key to the implementation of land redistribution legislation.

\begin{tabular}{|c|c|c|}
\hline Level & Official/Office & Function \\
\hline 3. District & $\begin{array}{l}\text { District Inpector of } \\
\text { Land Records } \\
\text { Deputy Collector }\end{array}$ & $\begin{array}{ll}\text { - } & \text { Aggregates revenue and taxes collected at the taluka } \\
& \text { level } \\
\text { - Oversees planning process and implementation of land } \\
\text { reforms } \\
\text { - Precisely surveys lands at the behest of the Mamlatdar's } \\
\text { office } \\
\text { - Decides which government lands to distribute } \\
\text { - } \quad \text { Conducts regular surveys of potential lands in } \\
\text { cooperation with the Agriculture Department }\end{array}$ \\
\hline \multirow[t]{4}{*}{ 2. Taluka } & $\begin{array}{l}\text { Block Magistrate } \\
\text { (Mamlatdar) }\end{array}$ & $\begin{array}{l}\text { - Gives public notice of all available lands } \\
\text { - Capable of identifying available Ceiling lands } \\
\text { - Technically capable of setting the land ceiling }\end{array}$ \\
\hline & $\begin{array}{l}\text { Revenue Circle } \\
\text { Officer }\end{array}$ & - Revenue and tax collection at the taluka level \\
\hline & Surveyor & $\begin{array}{l}\text { - Measures out the metes and bounds of allotted acreages } \\
\text { (does not use precise instruments) }\end{array}$ \\
\hline & $\begin{array}{l}\text { Government Lands } \\
\text { Committee }\end{array}$ & $\begin{array}{l}\text { - Decides which applicants will receive government lands } \\
\text { according to a prioritization hierarchy }\end{array}$ \\
\hline $\begin{array}{l}\text { 1. Village/ } \\
\text { Panchayat }\end{array}$ & Talati & $\begin{array}{l}\text { - Identifies lands in excess of the land ceiling } \\
\text { - } \text { Collects property tax ("land revenue") } \\
\text { - Maintains village 7-12 forms, which detail to what use } \\
\text { redistributed lands have been put }\end{array}$ \\
\hline
\end{tabular}

Source: the author.

\subsubsection{District Officials}

Officials called District Collectors supervise the implementation of land redistribution at the district level in Gujarat. District Collectors are charged with revenue and tax collection; overseeing the planning process and the implementation of land reforms (including the surveying of affected plots when necessary); and the quasi-judicial functions associated with the discretion to carry out the above. Most relevant to this study, the District Collector's office oversees several Deputy Collectors in selecting and certifying which government wastelands will be distributed to the public. All distributed lands must lend themselves to agriculture, and so the Deputy Collector's office conducts regular surveys in cooperation with the Agriculture Department to determine which 
parcels are cultivatable. Once the lands have been certified cultivable, the Collector's office places them on a list of available lands, and conveys this list to a taluka-level committee discussed below for consideration of redistribution applicants. Deputy Collectors are often referred to as operating at the "sub-district" level, but for the sake of convenience, I have amalgamated the two here.

Some Navsarjan staff consider Deputy Collectors often to share interests with local elites, as one-third are "homegrown" and most often come themselves from higher castes (Macwan 2007, Pers. Comm..). Some interviewees have postulated political considerations and pressures that bear on the decisions that District Collectors take. For instance, the right-wing Bharatiya Janata Party (BJP), the principal national opposition to the majority Congress Party, is especially strong in Gujarat. Given the BJP's support for such ideologically charged issues as Hindutva (conservative Hindu nationalism) and privatization, some speculate that the BJP has a hand in land redistribution for a few reasons. Most notably, they may advocate for the redistribution of public wastelands as an alternative to the redistribution of private agricultural lands under the Land Ceiling Act, which is anathema to their party philosophy.

Political bias at the district level is nonetheless unlikely, and difficult to prove, in any event. The new District Collector for Surendranagar District (a social liberal and, unusually, a woman) specifically noted the difficulty in transforming progressive Districtlevel policy decisions into results on the ground. She expressed her sincere wish to be able to do more for minorities oppressed by powerful landholders during her tenure as District Collector-refreshing candor after an interview with the Deputy Collector of the 
southern sub-district of Surendranagar, who systematically denied that zamindars, or even large landholders, existed after the ALCA reforms. (While statutorily abolished in 1952, Chakravarti [2004] contends that the move did not significantly weaken the traditional social base of land control.) Furthermore, the general perception among the vast majority of Dalit farmers interviewed for this study is that district-level officials are rarely corrupt and generally perform their job functions "objectively."

More general considerations also work against the political bias theory. The application procedure to become a District Collector is extremely competitive, the position highly respected and the remuneration decent—at around INR 20,000, or around USD 450, District Collectors earn salaries about five times as great as the average Navsarjan Land Redistribution Programme fieldworker (Majumdar 2006). District Collectors are recruited from two different agencies according to a formula. Two-thirds are recruited from within the Weberian and highly esteemed Indian Administrative Service (IAS), which is the direct organizational descendent of the illustrious Indian Civil Service begun under British rule. At IAS, would-be public administrators undergo specialized bureaucratic training and testing before being appointed to their respective posts by presidential fiat. One-third of District Collectors is recruited from within the state counterpart agency, the Gujarat Administrative Service (GAS). Before being posted to the District Collector position, though, these candidates must pass the standard IAS examinations and be promoted into IAS. The District Collector is intended to be politically and ideologically neutral, and has historically been subject to reassignment to any district in the federal government in the case that IAS deems it necessary to insulate 
him or her from local politics or, potentially, to placate district voters unhappy with the current Collector.

All the above considerations make corruption less likely. Moreover, it would be at best a monumental task, and, more realistically, simply impossible to attempt to uncover all the conceivable quid pro quos, deals, and intimated demands that may have gone into shaping District Collectors' decisions. For these reasons, it is most reasonable for a study of this scope to take the decisions of District Collectors at face value, and to treat them as the faithful reflections of State policy interfacing with the demographic influences in their local district.

The District Inspector of Land Records, despite the district-level position, is a marginal player in the land redistribution process. When called upon by a specific taluka Mamlatdar, the office will survey lands that have been allotted for redistribution, whether under the Land Ceiling Act or the government wasteland program. The surveys it performs are more precise than those of the surveyor from the local Mamlatdar's office. This office does not, however, keep centralized records of all lands redistributed as of now. These records are to be found only in the various Talati offices of local panchayats.

\subsubsection{Taluka-Level Officials}

The principal official concerned with land redistribution at the taluka-level is the Mamlatdar, or Taluka Block Magistrate. He chiefly deals with lands falling under the ALCA, and is, with the advent of computerized offices, capable of identifying 
landholdings in excess of the land ceiling (though this task customarily falls to the Talati). He is charged with giving public notice of all available lands, whether they be ceiling lands or government wastelands. The bulk of the ALCA cases were sorted out by the end of the 1980s, with two major pushes coming in 1969 and 1976 . Today, most of the remaining cases are those that were contested by the original owners, and are still bogged down in the courts. In urban areas, applications are made directly to the District Collector.

Interestingly, the Mamlatdar's office is also technically empowered to set the land ceiling for that particular taluka. In one focus group discussion with officials of Sayla taluka, Surendranagar district (Mamlatdar, Circle Revenue Officer, Sayla Talati) and Navsarjan fieldworkers, certain Navsarjan staff pressed the Mamlatdar to use this authority to lower the land ceiling for those lands capable of supporting higher-value crops. These fieldworkers suggested 25 acres for lands that can support rice all year, and 10 acres for those that can support sugar cane. Furthermore, they contend that this capacity should in particular be exercised in the near future as water diverted from the Narmada River via the infamous Narmada Canal drastically increases the value of nearby parcels. In practice, however, Mamlatdars defer to the benchmark set by the district, and presumably avoid the blame for setting unpopular land ceilings. When asked about this point, the Surendranagar District Collector stated simply that her office sets the threshold.

The Revenue Circle Officer is responsible for revenue collection on lands within his taluka. The surveyor measures out the metes and bounds of a parcel once the Government Lands Committee has designated a recipient. 
A Government Lands Committee convenes at the taluka level to consider the applications for available government lands published by the Mamlatdar. In the case of government lands, after publication of land availability, applicants prepare a statement that varies across districts to be submitted before the deadline. The Committee is convened by the District Collector, and has representatives from local special interest and minority groups (e.g., an SC, an ST, and an ex-serviceman); one representative of the panchayat, or village, government; and (according to the Surendranagar District Collector) occasional social workers and concerned citizens. The applicants are assessed based first upon location (with preference for those residing within 8 kilometers of the land), second on a prioritized list of preferred demographic groups, and third upon merit. The prioritization hierarchy for groups during the application process is as follows:

1) landless

2) scheduled tribes (STs)

3) scheduled castes (SCs)

4) agricultural cooperatives ${ }^{15}$

5) other backward castes (OBCs)

6) ex-servicemen

\footnotetext{
${ }^{15}$ Navsarjan fieldworkers believe that agricultural cooperatives generally do more harm than good, and that they should not receive the favor they do in the selection process. Fieldworkers are able to relate a number of stories of agricultural cooperatives that were formed by wealthy Dalits for the express purpose of becoming eligible for government agricultural subsidies and farm equipment grants targeted at such groups. Once these latter are obtained, the cooperative fails, with the founders keeping the equipment and the money, and the rest of the group left further impoverished. A notable exception to this pattern occurs in Paccham, where a cooperative of 16 households has adopted communal management. This rare successful model operates on the basis of equity ownership: to the extent that a member invests in the cooperative, thus boosting his equity share, he receiving a proportionally larger share of the produce.
} 
Combinations of these characteristics boost an applicant's likelihood for receiving land.

For instance, a cooperative society of local, landless STs with previous agricultural experience, say as agricultural laborers, would carry great weight.

\subsubsection{Village-Level Officials}

The Talati is the official closest to the ground, insofar as he comes in routine contact with land recipients and former large landholders. It is for this reason, and because he does not require the cooperation of any other official to make key decisions, that Navsarjan fieldworkers emphatically state that the Talati is the most corruptible of local politicians. He is expected to use his personal discretion to implement many of the land reforms discussed above, including the primary identification of landholdings that exceed the 54 acre land ceiling threshold. He also assists the taluka Revenue Circle Officer and Surveyor in surveying the metes and bounds of allotted parcels. The Talati also collects the local property tax (or "land revenue") based on a khatavahi, or land ledger that he conveys to land recipients and in which they in turn record their agricultural produce. Banks often make loans to farmers based on the data recorded in their khatavahis, making this a critical document attesting to one's asset-base and financial viability. In fact, Navsarjan fieldworkers assert that taking out agricultural loans from banks by collateralizing one's property can check upper-caste encroachment on the land, because bank officers (who now have a legal interest in the property via a lien) regularly audit the land. Finally, the Talati maintains the Village 7-12 forms from the information culled from khatavahis. The latter record the use government land has been put to following its

allotment. If, after three years, the land has not been "improved" in any way for 
agricultural use, it theoretically reverts back to the government, which re-publishes its availability.

\subsubsection{The Bureaucratic System at Work}

So what does the redistribution process look like from start to finish? The selection process will differ depending on whether lands are being distributed under the ALCA or the Government Lands Programme. The steps of both selection processes are laid out in Table 2.1.4-1, while the steps of the implementation process are enumerated in Table 2.1.4-2. Steps C1-C4 are illustrated in Figure B-1; G1-G4 in Figure B-2; I1-I6 in Figure B-3 (all found in APPENDIX B). As mentioned in Section 1.3.2, this study largely ignores the selection process for redistributed lands for want of reliable information, and instead concentrates on the implementation process. It is worth noting, however, that while the Government Lands Programme selection process involves cooperation (between the Deputy Collector's office and the Agriculture Department, and again in between the members of the Government Lands Committee) and the regular input of higher levels of government, the ALCA selection process involves low-level bureaucrats operating singly. 
Table 2.1.4-1. Selection processes for land recipients under the ALCA (designated $C$ ) and Government Lands Programme (designated $G$ ).

\begin{tabular}{|c|c|c|c|}
\hline Step & Agricultural Land Ceiling Act & Step & Government Lands Programme \\
\hline $\mathrm{C} 1$ & $\begin{array}{l}\text { The Talati (or Mamlatdar) identifies a parcel as } \\
\text { exceeding the 54-acre ceiling set for a single } \\
\text { owner, and the Mamlatdar notifies the District } \\
\text { Collector. The land is confiscated and } \\
\text { compensation paid. }\end{array}$ & G1 & $\begin{array}{l}\text { The Deputy Collector and the Agriculture } \\
\text { Department survey government lands and } \\
\text { identify cultivable parcels. }\end{array}$ \\
\hline $\mathrm{C} 2$ & $\begin{array}{l}\text { The District Collector authorizes land } \\
\text { redistribution and compensation for the original } \\
\text { landholder. }\end{array}$ & $\mathrm{G} 2$ & $\begin{array}{l}\text { The Mamlatdar publicizes the land's } \\
\text { availability in the local newspaper or other } \\
\text { media outlet. }\end{array}$ \\
\hline $\mathrm{C} 3$ & $\begin{array}{l}\text { The Mamlatdar publicizes the land's } \\
\text { availability in the local newspaper or other } \\
\text { media outlet. }\end{array}$ & G3 & $\begin{array}{l}\text { Hopefuls submit their applications to the } \\
\text { Government Lands Committee office. }\end{array}$ \\
\hline $\mathrm{C} 4$ & $\begin{array}{l}\text { Hopefuls submit their applications directly to } \\
\text { the Mamlatdar's office, which assesses the } \\
\text { applications itself. }\end{array}$ & G4 & $\begin{array}{l}\text { The Mamlatdar's representative brings the } \\
\text { applications to the Government Lands } \\
\text { Committee for evaluation, and conveys the } \\
\text { results of the deliberation back to the taluka } \\
\text { headquarters. }\end{array}$ \\
\hline
\end{tabular}

Source: the author.

Table 2.1.4-2. The process of implementing land reforms (designated $I$ ) is shared by both the ALCA and the Government Lands Programme.

I1 Mamlatdar informs the recipients of land awarded to them, as well as its approximate location.

I2 Recipient confirms to the Mamlatdar his intention to cultivate the land.

I3 The Revenue Circle Officer, Surveyor and Talati convene at the parcel to mark the bounds and notify the successful applicant(s) of the exact measurements taken. ${ }^{16}$

I4 The Talati conveys the khatavahi, or land ledger, to the land recipients.

I5 Recipients take possession and begin to pay land revenue to the Circle Revenue Officer.

I6 In the case of a boundary dispute or need of more precise clarification on metes and bounds, the Mamlatdar requests the office of the District Inspector of Land Records to send a more highly trained surveyor.

Source: the author.

\subsection{A Simplified Analysis of Government's Impact on Redistribution}

This subsection examines via regression analysis the contention that the government hierarchy is a contested terrain, with powerful local interests at the ground level pushing upward through nested local governments against central redistributive legislation. From this idea flow a couple of testable hypotheses:

\footnotetext{
${ }^{16}$ This is a controversial moment, and can draw a hostile crowd. Therefore, the Mamlatdar's office will sometimes bring along a police escort to see that possession can be handed over peacefully. Navsarjan employees contend that police escorts are not provided nearly often enough.
} 
1. The explanatory power of the statistical models will fall as they attempt to analyze consecutively higher levels of government, because powerful community interests and ground-level factors will be felt less intensely; and (a corollary)

2. The influence of the local upper-caste community will be felt more strongly in governments that are closer, both geographically and institutionally, to the locality in question, and farther from the immediately superior local government headquarters. This hypothesis reflects the transaction costs involved in government monitoring and communication in rural Gujarat.

Forgetting for a moment the chronological complexity of the bureaucratic interactions described in Section 2.1, I now attempt to simplify the layers of policy implementation drastically for the sake of analytic convenience. Table 2.2-2 categorizes many of the most important system "breakdowns" by level of government, from Level 0 (ground level) to Level 1 (village level) to Level 2 (taluka level). The district level is not considered here because it is primarily involved in the assessment and selection processes, and because it falls outside this study's scope to make inter-district comparisons. In the analysis of the 2006 survey data, each potential breakdown is treated as a dummy variable ( 1 or 0 , respectively signifying "breakdown" or "no breakdown"). Certain variables are treated as continuous dummy variables (i.e., they range from 0 to 1 , where 1 means the breakdown occurred totally, 0 signifies that no breakdown occurred at all, and a fractional amount indicates to what extent the breakdown occurred). These dummy variables are then aggregated and attributed to the corresponding level of government for each landowner interviewed. Table 2.2-1 lists the control variables available and their sources. 
Table 2.2-1. Levels of Sub-District Government and Their Potential for Implementation Breakdown. Continuous dummy variables are marked with an asterisk $(*)$. Variables of questionable categorical fit are in parentheses.

\begin{tabular}{lrl} 
Government Level & Breakdown \\
\hline 2: Taluka & - & The survey was not performed* \\
& - & Title was not conveyed \\
& - & (An easement was never established) \\
\hline 1: Village/Panchayat & - & Khatavahi, or land ledger, was not conveyed \\
& - & Khatavahi was not amended to reflect new land allotment \\
& - & An encroachment exists on paper* \\
& - & (An easement was never established) \\
\hline 0: Ground & - & A hostile incident while taking possession \\
& - & An encroachment exists in reality* \\
\hline
\end{tabular}

Source: the author.

Table 2.2-2. Control variables and their sources.

\begin{tabular}{lll} 
Source & Control Variables \\
\hline 2006 Survey & - & Land type (ALCA versus government lands) \\
& - & Acres of parcel in question \\
& - & Value per acre of parcel in question \\
\hline GIS (created by author ${ }^{17}$ ) & - & Distance of the village from the taluka headquarters \\
& - & Distance of the village from the district headquarters \\
State Below Poverty Line & - & Distance of the taluka headquarters from the district headquarters \\
(BPL) survey & - & Percentage of the village population below acute poverty line \\
& & (Government index 1-5) \\
& - & Percentage of the village population below severe poverty line \\
& & (Government index 1-10) \\
& - & Percentage of the village population below severe moderate poverty \\
& & line (Government index 1-15) \\
& - & Percentage of the village population below poverty line \\
& & (Government index 1-20) \\
\hline Census of India 2001 & - & Total population of the village \\
& - & Literacy rate \\
- & Scheduled Castes as a percentage of village population \\
& - & Main agricultural laborers as a percentage of village population \\
- & Marginal agricultural laborers as a percentage of village population \\
& - & Working population generally as a percentage of village population \\
\hline
\end{tabular}

Source: the author.

Government-level breakdowns are defined as failures of the government bureaucracy to

fulfill the functions of its intended and mandated role in the redistribution process.

Breakdowns on the ground level, by contrast, consist of social and community pressures

that are actively brought to bear for the purpose of discouraging Dalit land possession. I

\footnotetext{
${ }^{17}$ Considering the extreme unreliability of GIS data for Gujarat, the distances are not measured using network analysis of the road system, but rather simply "as the crow flies."
} 
argue that violence "on the ground" emerges under institutional conditions favorable to the persistence of horizontal socioeconomic stratification and coincidence of social and economic status. A certain positive circular reinforcement is at work: institutions may allow for continued de facto "patrimonialism," and in turn powerful landlords benefiting from the social arrangement push for their brand of local government. ${ }^{18}$ The trick, then, is to understand how the cycle can be reversed.

The first type of ground-level breakdown occurs if hostility erupts at the scene of a survey where the Circle Revenue Officer, Talati, and taluka Surveyor arrive to mete out the land. This is especially so with ALCA cases, where there is almost always a de facto upper caste "encroacher" (the original owner) $-12.3 \%$ of ALCA land recipients reported some form of aggression upon taking possession of their lands, versus only $3.6 \%$ of government lands recipients ${ }^{19}$. In the latter case, government lands may have already been under cultivation by others-sometimes (but not always) upper-caste members. For instance, in Kanpur village, Dalits reported that the village Darbars (members of the Kshtriya caste) allowed other forward caste members to cultivate local government lands, but forbade local Dalits doing likewise. By contrast, in Shiyen village, located in a region with a large tribal population, Dalit recipients of a 100 -acre pre-independence land concession had been effectively bullied off of 50 acres by the more numerous indigenous farmers. The second type of ground-level breakdown occurs when a hostile encroacher

\footnotetext{
${ }^{18}$ Sharuna (1998) argues that the transition from feudalism, as embodied in the Zamindari system, to what he terms the "patrimonialism" that characterized post-independence land relations consisted of a shift from the supremacy of those skilled in war to those who require, and take advantage of, the legal system and government officials to legitimize their power. Thus, while the Zamindari system was a system of production in which Zamindars depended upon the Marxian appropriation of a peasant surplus, patrimonialism can be seen in a more Weberian tradition as a social system, too.

${ }^{19}$ This difference is significant with a Chi-Square test at the $99 \%$ level.
} 
prevents the Dalit title recipient from making beneficial use of his/her land. The encroachers were often the owners or de facto cultivators of the land prior to redistribution.

\subsubsection{General Trends in Regression Results for Breakdown Predictors}

The statistical models predicting breakdowns prove more powerful at lower levels of policy implementation. They are able to account for around $39 \%$ of the variation in breakdowns arising at the ground levels, fall to $34 \%$ at the village level, and fall again to 11-19\% explanatory power at the taluka level. This trend suggests that local conditions and local interests have less influence on policy implementation efforts that occur at progressively higher levels of government. It should be noted, however, that a few independent variables with village-specific characteristics (e.g., the Below Poverty Line data) might naturally be expected to produce this trend, since they would apply directly to ground- and village-level phenomena, but only constitutively to higher-order phenomena.

\subsubsection{Ground-Level Breakdowns}

Village Government's Role. The predictors of ground-level breakdowns are listed in descending order of influence in Table 2.2.2-1 (see APPENDIX C, Tables C-1and Tables C-2 for more complete statistical results). Most strikingly, village-level governments that present many obstacles for Dalits during the redistribution process are strongly indicative of a fraught environment on the ground, as well. Ceteris paribus, for every ten obstacles that a village-level government presents, another 4.5 obstacles are generated at the ground level. In the course of the interviews for this study the most oft-cited explanation for this synergistic phenomenon is the fact that strong village elites often control the local 
government, aligning political interests with those of large landholders and creating a favorable environment for further Dalit oppression on the ground.

In Devaliya village, Sayla taluka, for example, the powerful Darbar "village king" successfully does just that. He retains stoutly hierarchical views of caste's role in society, and has strong connections to the local government. Though he speaks protectively and patronizingly of local Dalits, he bemoans the partial devolution of economic power to lower castes. During the interview he gave for this study, he pointed out a member of the Patel jati who was listening in and, within easy earshot, explained that in his grandfather's time, that Patel blithely smoking a bidi in front of him would not even have been allowed to wear shoes in his presence. When asked to describe his relationship with the talati, the "village king" offered to call him and order him to attend our interview. He added that the talati would come even at midnight if he called, and that he (the Darbar landholder) retains enough social standing to decide who will be sarpanch (village mayor). Although the latter position is technically elected, it is not unusual in small villages for the descendents of zamindars to tell villagers for whom they should vote. Given the cyclic nature of the relations between village government and caste relations in village social life, I also performed the analysis using two-stage least-squares analysis, but obtained nearly identical results to those reported in Table 2.2.2-1 (see APPENDIX C, Tables C-2). 
Table 2.2.2-1. Determinants of breakdowns in redistribution implementation at the ground level in decreasing order of importance.

\begin{tabular}{lrl} 
Rank & $\begin{array}{c}\text { Standardized } \\
\text { Coefficient }\end{array}$ & Independent Variable \\
\hline $\mathbf{1}$ & $0.448^{* * * *}$ & Government Breakdowns at the Village Level \\
$\mathbf{2}$ & $-0.310^{* * *}$ & Distance of the village from the taluka headquarters \\
$\mathbf{3}$ & $0.306^{* * *}$ & Percentage of the village population below poverty line (government index 1- \\
& 20 ) \\
$\mathbf{4}$ & $0.266^{* * *}$ & Working population generally as a percentage of village population \\
$\mathbf{5}$ & $0.244^{* * *}$ & Marginal agricultural laborers as a percentage of village population \\
$\mathbf{6}$ & $-0.219^{* * *}$ & Land type (ALCA versus government lands) \\
$\mathbf{7}$ & $0.180^{* * *}$ & Distance of the taluka headquarters from the district headquarters \\
$\mathbf{8}$ & $0.129^{*}$ & Value per acre of parcel in question \\
$\mathbf{9}$ & $0.126^{*}$ & Main agricultural laborers as a percentage of village population \\
\hline Explanatory power $=39 \% ; * * *=99 \%$ confidence level; $* *=95 \%$ confidence level; $*=90 \%$ confidence \\
level. & \\
Source: Navsarjan 2006 survey data, author's calculations.
\end{tabular}

Geographic Distance. The impact of geographic distance on administration plays a key role in establishing the administrative hierarchy as a contested terrain (see for a map of Surendranagar district and its villages). On the one hand, the greater the distance between the local taluka headquarters and district headquarters (the latter being Surendranagar City in this case), the likelier it is that the redistribution process will stall for social reasons. Navsarjan fieldworkers explain this correlation by saying that long travel times lead to reduced district-level supervision, which in turn breeds corruption at taluka headquarters. Consequently, fieldworkers contend that taluka magistrates are less likely to use scarce resources to pay for police escorts during surveys and easement allotments (a not-infrequent requirement to which the Sayla mamlatdar admits), and local mobs may more easily influence the survey procedure or physically prevent the Dalit beneficiary from taking possession.

On the other hand, greater distances between the village and taluka headquarters generally result in an even larger decrease in breakdowns occurring on the ground. Assessing the 
situation under the paradigm of top-down administration, this finding would appear counter-intuitive. In parallel with the above finding, shouldn't one expect to find that as the distance grows, it becomes more difficult for taluka officials to ensure that redistribution measures are carried out on the ground? In fact, this finding may be evidence for the view that influence in the administrative structure runs bi-directionally. After all, the farther away the taluka headquarters, the less pressure can be brought to bear on taluka officials by large landholders. The taluka officials interviewed for this study admitted to being under constant pressure to balance the interests of "the community." One mamlatdar said that he tried to limit his exposure to undue pressure-i.e., bribes, threats, and such—by developing two mutually exclusive identities: one a government bureaucrat, one a community-member. By contrast, the Deputy Collector interviewed, even further removed from local interests, took offense at any implication that he might be subject to social pressures that would compromise his neutrality.

Furthermore, Dalits in villages in closer proximity to the taluka headquarters may also be, by definition, in closer proximity to the closest agricultural market. This fact would increase Dalit access to markets, thereby reducing their dependence on large-scale farmers with storage capacity. This alternative explanation would suggest an economic backing to increased political power. However, this study did not obtain information on specific market towns frequented by Dalit farmers, and thus was unequipped to hold this variable constant. 


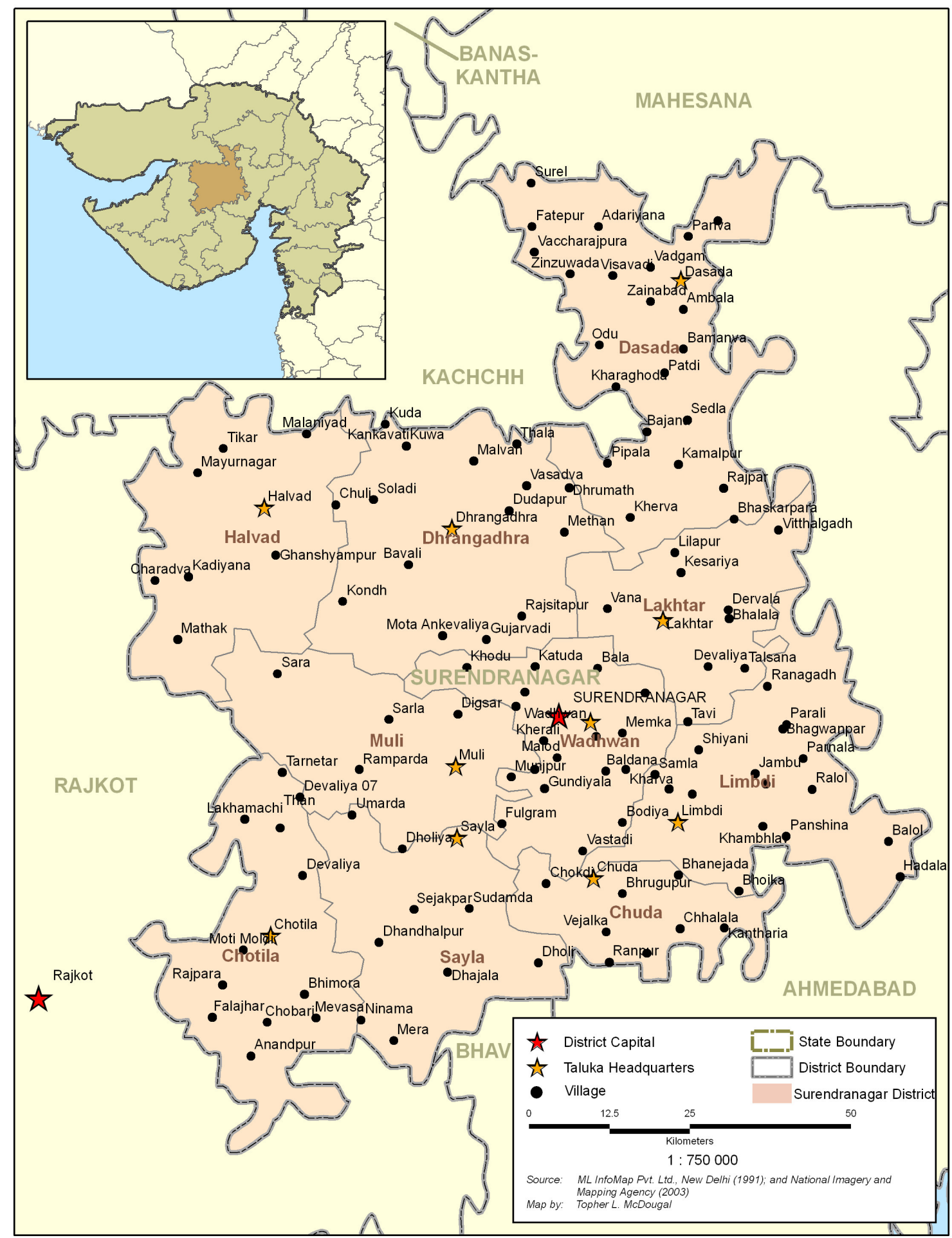

Figure 2.2.2-1. Map of Surendranagar district depicting villages, taluka headquarters, and district headquarters.

Poverty. Large population percentages below the poverty line is also a strong, reliable predictor of ground-level breakdowns. One possible reason is that Dalits tend to be 
poorer than upper-castes (Rajagopal et al. 2006), and the poverty-stricken are less likely to have the means necessary to cultivate an agricultural parcel successfully and sustainably. Sayla Taluka officials reported that the three most daunting challenges facing a prospective Dalit farmer are:

- improvement costs (especially with government lands that require extensive leveling, fertilization, etc.);

- variations in rainfall, as Gujarat is a desert state and much of the land is dryfarmed rather than irrigated; and

- market prices, which tend to be low. Not only do small farmers often compete with subsidized, industrial-scale operations, but they also have little to no storage capacity for their produce, and equally little savings. Since these small farmers are inherently price-takers on the market, and since they are unable to wait out price troughs, they are likely to sell low to larger farmers with greater storage capacity and savings.

All three of these factors make Dalits particularly vulnerable from an economic point of view, especially those on government lands. This is born out by the proportion of land recipients who have since sold their land: 9.2\% amongst government lands recipients, as opposed to $2.1 \%$ amongst ALCA recipients. Another conceivable, but less convincing, explanation is that, to the extent upper-caste members find themselves below the poverty line, they may be more desperate to reclaim their land and have fewer recourses to official channels than their wealthier counterparts.

Labor Market. Three of the eight significant predictors of ground-level breakdowns had to do with the "thickness" of the local labor market. Indeed, when added together, these 
factors outweigh any other single factor. The factors include the village proportion of marginal agricultural laborers, that of the labor force in general, and that of main agricultural laborers. All three are positively correlated to breakdowns on the ground, meaning that thicker labor markets generate more social tension around land redistribution than do thin ones. Not surprisingly, the strongest influence of the three labor variables is that of the proportion of marginal agricultural laborers. Most of the Dalits interviewed for this study had been, prior to land redistribution measures, migrant (and therefore marginal) agricultural laborers. ${ }^{20}$ Most continued to migrate despite the reforms (around 53\%), though some survey respondents falling into this category reported that ownership of a small landholding effectively reduced the number of months during which they migrated. Many more have not stopped migrating at all. ${ }^{21}$

Migrant laborers have very little power, economic or otherwise, within their communities. Without official residency, they may not vote for local officials or send their children to public schools. It is also not in migrants' best interests to invest heavily in long-term assets such as property, and most live in "katcha," or thatch/multi-media houses. Ranging from in their contribution to total population across the sampled villages from negligible to almost $20 \%$, the presence of migrant laborers generally depresses the going wage for agricultural labor (Navsarjan 2000b). This is partly due to the fact that migrants do not have recourse to local officials who might enforce minimum wage laws. With low incomes and little collateral, they are also subject to ruinous

\footnotetext{
${ }^{20} 69.3 \%$ of survey respondents had previously been employed as agricultural laborers.

${ }^{21}$ Around $6.4 \%$ of survey respondents formerly employed as agricultural laborers reported reduced, but not eliminated, periods of migration. This is against the much more promising figure of $47.0 \%$ of agricultural laborers who stopped migrating entirely, leaving $46.6 \%$ who have not stopped or reduced their seasonal
} 
interest rates on loans, sometimes over $200 \%$ yearly interest (ibid.). The period of indebtedness may stretch out for years, sometimes into subsequent generations. Navsarjan (ibid.) has documented bonded laborers constituting up to $8 \%$ of the Dalit agricultural labor pool in selected Gujarati villages. It is indeed easy to comprehend Navsarjan's Marxian view that Dalit agricultural laborers, and especially migrants, constitute an oppressed class—a sort of pre-Industrial Reserve Army. ${ }^{22}$

In view of this background, one can hypothesize a number of ways that agricultural laborers might indirectly contribute to the erection of redistribution obstacles on the ground. For one, the depressed wages they cause might lessen land recipients' ability to make necessary improvements to their land. In the longer run, the presence of a cheap agricultural labor force may enable the persistence through time of "outmoded" socioeconomic arrangements. A corollary hypothesis would be that the absence of cheap labor makes it less feasible for absentee landlords profitably to farm their holdings. Finally, to the extent that Dalit migrant laborers find themselves the recipients of redistributed lands, they may exhibit handicaps above and beyond those of other Dalits, such as debt carried over from their former existence, and a lack of "social capital" or networks.

Land Type. Recipients of government land have, other considerations equal, 22\% fewer ground-level obstacles to contend with than do recipients of ALCA lands. Presumably,

migrations. These numbers significantly favor ALCA recipients over government lands recipients (see Appendix C).

${ }^{22}$ With migrant labor's effects on local wages in mind, consider for instance the following quote from Capital: 
this is because, in addition to social taboos against Dalit land ownership, ALCA land recipients have to contend with former landowners seeking to retain control over their former properties. Section $\mathbf{2 . 3}$ delves more deeply into the differences between these two types of lands.

Land Value. Predictably, the higher the value of the parcel in question, the more likely obstacles to Dalit cultivation will arise in the community. This simple fact reflects the great desirability of fertile lands in a semi-arid landscape. The government wastelands awarded to a Dalit farmer in Vandavar village serve as the subject of a natural experiment, conveniently separating the issue of land use from soil quality. Members of the upper-caste Patel community do not vie for control over the land itself, as it forms the bed of a seasonal lake behind a reservoir dam, and is thus only tillable for six months of the year. Instead, the Patels choose to cart off the rich alluvial topsoil from the land as the lake waters recede at the beginning of winter.

\subsubsection{Village-Level Breakdowns}

As when assessing breakdowns at the ground level, breakdowns at the village level (see Table 2.2.3-1, and APPENDIX C, Tables C-3) are most strongly encouraged by breakdowns one level up — at the taluka level. Like before, the presence of poverty also correlates positively with breakdowns. Interestingly, though, a negative coefficient is associated with a more extreme category of impoverished villagers, leaving only a mild positive correlation, attributable principally to the uppermost crust of the poor (i.e., those rated 16 to 20 on the government Below Poverty Line, or BPL, scale, where 1 is the most 
dire category). It is difficult to interpret this result definitively, especially since the BPL data applies to the aggregate village level (i.e., it speaks to the percentage of poor in a village) instead of the individual/household level, which is the survey's unit of analysis. However, one might theorize that the wealthiest of the poor benefit from the redistribution measures to a larger extent than do the most vulnerable demographics.

Table 2.2.3-1. Determinants of breakdowns in redistribution implementation at the village level in decreasing order of importance.

\begin{tabular}{|c|c|c|}
\hline Rank & $\begin{array}{l}\text { Standardized } \\
\text { Coefficient }\end{array}$ & Independent Variable \\
\hline 1 & $0.454 * * *$ & Government breakdowns at the taluka level \\
\hline 2 & $0.214 * *$ & $\begin{array}{l}\text { Percentage of the village population below poverty line (Government index 1- } \\
\text { 20) }\end{array}$ \\
\hline 3 & $0.212 * * *$ & Distance of the taluka headquarters from the district headquarters \\
\hline 4 & $-0.184 * *$ & $\begin{array}{l}\text { Percentage of the village population below poverty line (Government index 1- } \\
15)\end{array}$ \\
\hline 5 & $0.152 * * *$ & Village literacy rate \\
\hline 6 & $0.113 * *$ & Marginal agricultural laborers as a percentage of village population \\
\hline 7 & $.109 *$ & Distance of the village from the taluka headquarters \\
\hline
\end{tabular}

Geographic distance again plays an important role in shaping village-level support for land redistribution. The farther the taluka headquarters is from the district headquarters, the more barriers the village government puts up to redistribution measures, presumably owing to a weaker connection to progressive state policy. Likewise, long distances from the village to the taluka headquarters also contribute to village-level breakdowns. Here, we may want to pause for reflection, though: previously, we saw that increasing distance between village and taluka decreased breakdowns at the ground level. Why should the village level be any different? I would argue that we are observing two distinct pathways of influence, each running in the opposite direction. That is, the effects at the ground 
level stem from the ability (albeit decaying over distance) of community members to influence taluka government through personal petition-a right they are entitled to, and do, exercise, as we heard from the Sayla mamlatdar. However, the verticalized influence pathways within the nested structure of local government are not designed to flow upward. Information may flow upward, as in the case of talatis alerting mamlatdars to the presence of ALCA-eligible lands, who in turn then alert the Deputy and District Collector. However, policy only flows (again, decaying with distance) downward.

The weaker contributing factors to village government regressiveness largely resemble the ground level findings, save for one additional variable. In parallel with the groundlevel analysis, village-level breakdowns rise mildly along with the proportion of the population in the top echelon of the BPL villagers only. Likewise, the proportion of migrant agricultural laborers also correlates with village-level breakdowns. Finally, however, the village literacy rate (a measure of little statistical significance at the ground level) also comes into play, fluctuating in sync with village government breakdowns. This variable should be regarded with skepticism, for, like the BPL proportions, it represented an aggregated, village-level datum that is imputed to household level data. Positing for a moment the existence of a completely neutral and objectively functioning panchayat government, however, the finding is nonetheless surprising. In an objectively operating village government, we might expect a low literacy rate to adversely affect the quality of applications for lands to be redistributed, and therefore decrease the likelihood that the village government would process the applications efficiently. However, we find just the opposite. 
One conceivable (but cynical) explanation for this paradox is that village officials allied with local large landholders systematically create more problems when literacy rates rise in the hopes of counteracting a shift toward equity. A more likely explanation is that villages with lower literacy rates will tend to have fewer applicants in general (due to lack of access to knowledge about the process and availability of lands), and will therefore be freed up to process the remaining applications with greater care. Some anecdotal evidence for this explanation is provided by a Navsarjan fieldworker for Sayla taluka; she says that she constantly wages a battle against villagers' lack of knowledge about lands availability. Furthermore, when asked about his own greatest personal frustrations, the Sayla talati complained that he had so few personnel to deal with an overwhelming number of applications. He went so far as to extol the state's recent ban on applications coming from ex-servicemen from without the district.

A cursory quantitative analysis would tend to support the second explanation of the literacy paradox. A histogram of Dalit land recipients surveyed broken out by their village's literacy rate (see the left-hand side of Figure 2.2.3-1) reveals a negativelyskewed distribution. Nor is this characteristic simply a representing the population as a whole: the right-hand side of Figure 2.2.3-1 shows the same histogram format applied to every village in Surendranagar district $(\mathrm{N}=748)$, and the result is a very gently positively-skewed distribution. The contrast between the two would suggest that the application process for redistributed lands acts as a filter for villages with low literacy rates. In most cases, and especially in the lower end of the literacy rate spectrum, higher marginal literacy rates do in fact lead to more applications for land redistribution. Since the Navsarjan survey did not target Dalits in random fashion (thereby collecting responses 
from those who had not applied for or received lands at all), it is difficult to derive the relative importance of literacy's benefits and costs. However, if the proffered explanation is accepted, it is fair to say that literacy rates do not cause breakdowns at the village level, but rather constraints on administrative capacity do.
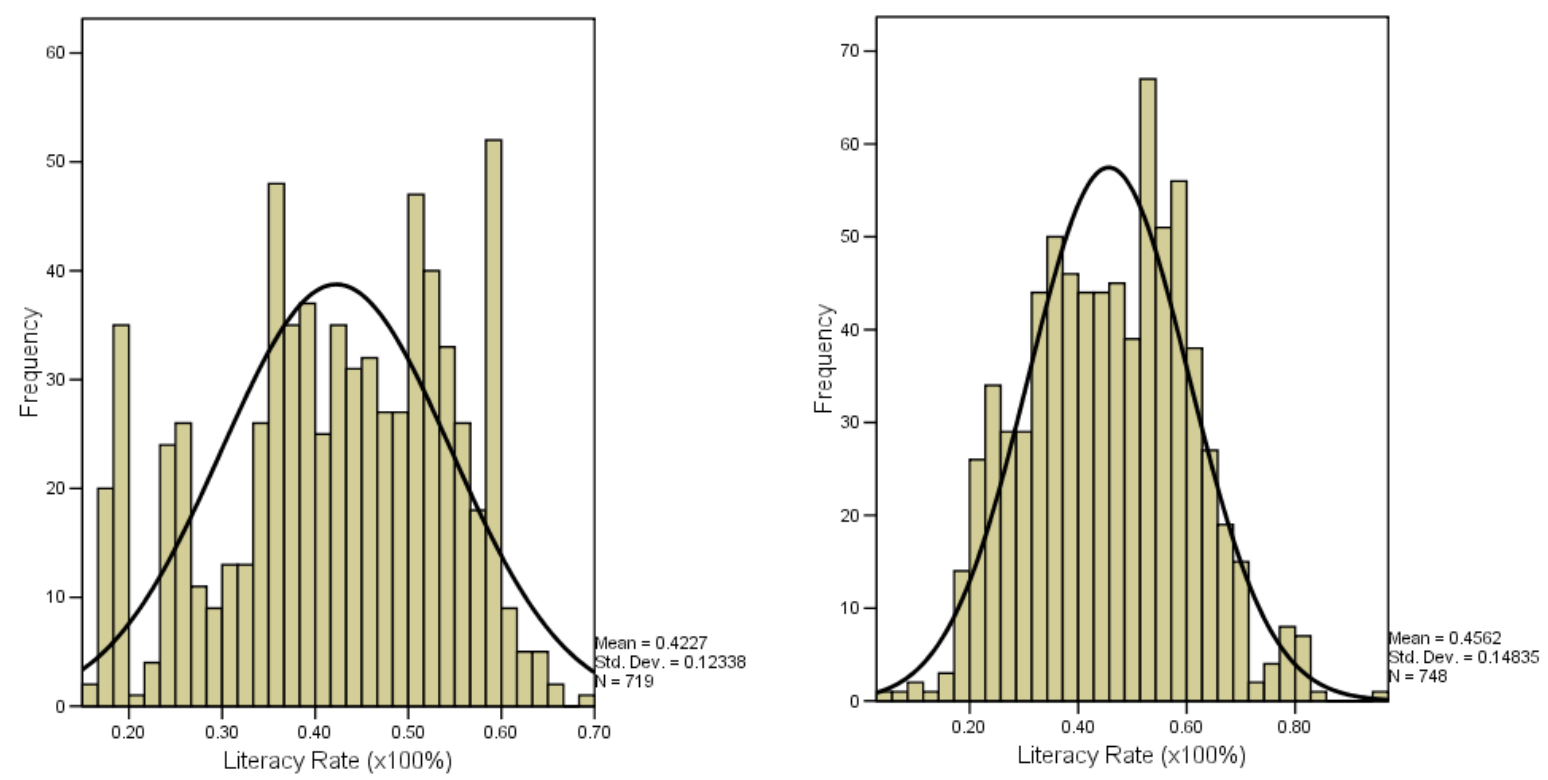

Figure 2.2.3-1. Histograms of Dalit land recipients surveyed (left) and Surendranagar district as a whole (right), both disaggregated based on literacy rate. Would-be normal curves are displayed in black. Skewness (left) $=-0.340$; skewness (right) $=0.046$.

Source: 2006 survey data and the Census of India 2001; histograms by the author.

\subsubsection{Taluka-Level Breakdowns}

Breakdowns in land reform implementation at the taluka level take the form of either a failure to supply a title to the land in question, or a failure to survey the land. The latter point more nuanced than it seems at first. Survey-related threats to the redistribution process typically occur in two major variants:

- A failure to survey, in whole or in part. This problem is one of the present study's criteria for measuring taluka-level breakdowns. It occurs more frequently 
in the case of government lands than with ALCA lands. An astonishing 35.1\% of government lands recipients in Surendranagar district reported an unperformed or incomplete survey of their lands, as opposed to only $17.5 \%$ among recipients of ALCA lands. ${ }^{23}$ It is true that ALCA lands were usually awarded before government lands, and so have had more of an opportunity to be surveyed, but neither category is particularly new. Navsarjan field staff reported, for instance, that in Ranagar village, armed encroachers prevented survey crews from meting out a parcel of government land. One possible explanation for the variance in survey enforceability is that lands falling under ALCA jurisdiction are presumably less likely to be designated as eligible for redistribution in the first place, since this involves the talati or mamlatdar identifying them as such. Therefore, the comparison is skewed from the beginning, and prospective ALCA lands that might have brought out the armed encroachers upon survey, are still safe in the hands of the original landowners;

- A failure to provide a necessary easement. Many Dalit farmers (29\% among ALCA recipients, $14.9 \%$ among government lands recipients) reported receiving land unaccompanied by an easement necessary either to access or irrigate it. Interviews with Dalit land recipients in Vanta Vachh village, Sayla Taluka, claimed that the reason for this is that any prospective easement for their land would necessarily run through Darbar private property, and thus was not granted. Navsarjan field staff indicate that ALCA lands exhibit this characteristic more often simply because redistributed private land tends to be located near unredistributed private land, whereas government lands tend to be near other

${ }^{23}$ A significant difference at the $99 \%$ confidence level. 
government lands. Critically, this issue is related to that of survey failures, in that upper-caste landowners may often choose which part of their land will be surveyed for redistribution. Not only does this practice ensure that the worst of private lands is conveyed by the redistribution mechanism, but also makes it likely that the parcel will be inaccessible from public roads, further decreasing the likelihood of actual possession. Despite its strong causal connection with the first survey-related problem, Navsarjan staff claim that taluka officials do not often take up the easement question, and it is thus not included in the first analysis.

Fewer local factors have impacts on taluka-level implementation breakdowns than on those at the village level, and the model loses much of its explanatory power. The most significant determinant of taluka-level breakdowns is the proportion of the village population below the poverty line (see Table 2.2.4-1, and APPENDIX C, Tables C-4). Again, great geographical distances separating the taluka from the district headquarters are also related to breakdowns. Interestingly, while the proportion of the population designated as Scheduled Castes did not influence outcomes at lower levels, at the taluka level, applications from Dalit-heavy villages are more likely to encounter problems. As with the literacy rate, we might hypothesize that villages with many Dalits also produce many applications, overwhelming the taluka's capacity to cope. Corroborating this notion, the Sayla taluka surveyor stated that he was the only surveyor for 75 villages, and that his office was seriously understaffed. Finally, small parcels appear to get overlooked at the taluka level. One possible reason for this is that survey errors have a larger impact on small parcels, since the dummy variable for survey breakdowns runs continuously from 0 to 1 , depending on the proportion of the parcel not surveyed. 
Table 2.2.4-1. Determinants of breakdowns in redistribution implementation at the taluka level in decreasing order of importance (easement difficulties excluded).

\begin{tabular}{lrl} 
Rank & $\begin{array}{c}\text { Standardized } \\
\text { Coefficient }\end{array}$ & Independent Variable \\
\hline $\mathbf{1}$ & $.272 * * *$ & $\begin{array}{l}\text { Percentage of the village population below poverty line (Government index 1- } \\
20 \text { ) }\end{array}$ \\
$\mathbf{2}$ & $.160 * * *$ & Distance of the taluka headquarters from the district headquarters \\
$\mathbf{3}$ & $-.185 * * *$ & Scheduled Castes as a percentage of village population \\
$\mathbf{4}$ & $-.193 * * *$ & Acres of redistributed parcel \\
Explanatory power $=10.6 \%$. & $* * *=99 \%$ confidence level; $* *=95 \%$ confidence level; $*=90 \%$ confidence \\
level. &
\end{tabular}

Interestingly, when easement-related problems are attributed to the taluka government, geographical distances (village-to-district, village-to-taluka, and taluka-to-district) account for the three strongest predictive factors. Furthermore influence of local village conditions strengthens markedly and the explanatory power of the model rises in step (see Table 2.2.4-2, and APPENDIX C, Tables C-5). As the distances between villages and taluka headquarters, and taluka and district headquarters, rise, so to do the costs of covering those distances. On issues of surveying and title allotment, the mamlatdar's office (and particularly the surveyor and Revenue Circle Officer) is directly accountable to the Deputy and District Collectors. Therefore, it is reasonable to suppose that greater distances lower accountability and increase discretion. Similarly, as the distance rises between the taluka office and the village, it becomes less likely for the survey process to be performed with all three mandated participants: Revenue Circle Officer, surveyor, and talati. Since the two most likely not to be present as a result of great distances are the Revenue Circle Officer and the taluka surveyor, the process may be relatively more influenced by the talati (who, as we have established, often serves at the pleasure of the local large landholder) and the gathering villagers. Even if both taluka officials are present to mete out the property, the taluka police may be less likely come great distances, 
and mobs of encroachers may intimidate the officials (see Subsection 2.2.2). Conversely, the closer the village is to the district headquarters, the less likely taluka-level breakdowns are to occur. The preeminently likely explanation for this phenomenon is that the survey does not ask which institution performed the land survey. Most often, it is the taluka surveyor, but in the case of a dispute or complaint, the matter goes to the district land surveyor in Surendranagar (step 6 in Figure B-3). Therefore, the lower the transaction costs involved in notifying the district land surveyor and getting him or her to resurvey the land, the likelier it is that taluka-level problems can be remedied. Again, we see that the local government hierarchy is host to multiple competing interests that in turn have multiple avenues for advancing their interests.

Table 2.2.4-2. Determinants of breakdowns in redistribution implementation at the taluka level in decreasing order of importance (easement difficulties included).

\begin{tabular}{lrl} 
Rank & $\begin{array}{c}\text { Standardized } \\
\text { Coefficient }\end{array}$ & Independent Variable \\
\hline $\mathbf{1}$ & $-0.458 * * *$ & Distance of the village from the district headquarters \\
$\mathbf{2}$ & $0.327 * * *$ & Distance of the village from the taluka headquarters \\
$\mathbf{3}$ & $0.303 * * *$ & Distance of the taluka headquarters from the district headquarters \\
$\mathbf{4}$ & $0.278 * * *$ & Main agricultural laborers as a percentage of village population \\
$\mathbf{5}$ & $-.196 * * *$ & Scheduled Castes as a percentage of village population \\
$\mathbf{6}$ & $-.174 * * *$ & Village literacy rate \\
$\mathbf{7}$ & $.147 * *$ & Percentage of the village population below poverty line (Government index 1- \\
& 20 ) \\
\hline Explanatory power $=19.3 \%$. $* * *=99 \%$ confidence level; $* *=95 \%$ confidence level; $*=90 \%$ confidence \\
level. \\
Source: Navsarjan 2006 survey data, author's calculations.
\end{tabular}

\subsection{Differential Treatment of ALCA and Government Lands}

The implementation of the land reforms impacts ALCA and government lands

differentially (see Figure 2.3-1). Generally speaking, recipients of ALCA lands are plagued with more and greater hurdles to cultivation than government land cultivators when dealing with their local governments or their communities. Surveyors perform their 
mandated duties less frequently. Talatis will more easily allow the distribution of lands without access easements, as well as the persistence of encroachments on official village records. On the ground, community members are more likely to resort to threats, violence, and intimidation to keep Dalits from farming, and encroachers are more likely to resist ejection.

Two notable exceptions prove the rule: official title is more often granted to ALCA recipients than to government land farmers, and the khatavahis, or land ledgers, are more reliably provided to them. This may be because most ALCA parcels were redistributed earlier than most government wastelands, at a time when less overall demand for agricultural land existed. Thus, district, taluka, and village land offices may not have found themselves in the state of over-taxation to which many interviewed bureaucrats alluded. Another, more cynical, explanation is that, since the ALCA is the state government's flagship land reform program and is consequently subject to a incessant public scrutiny, it behooves district collectors to distribute the largest possible proportion of the officially-declared ALCA land titles. Under this alternative explanation, whether lower government offices take the necessary steps to ensure those titles are more than empty promises is of less concern. Whatever the reason, it is interesting to note that despite the greater desirability of ALCA lands with respect to government lands, the incidences of encroachment are quite comparable - perhaps because the selection process of ALCA lands tends not to redistribute the majority of eligible properties. 


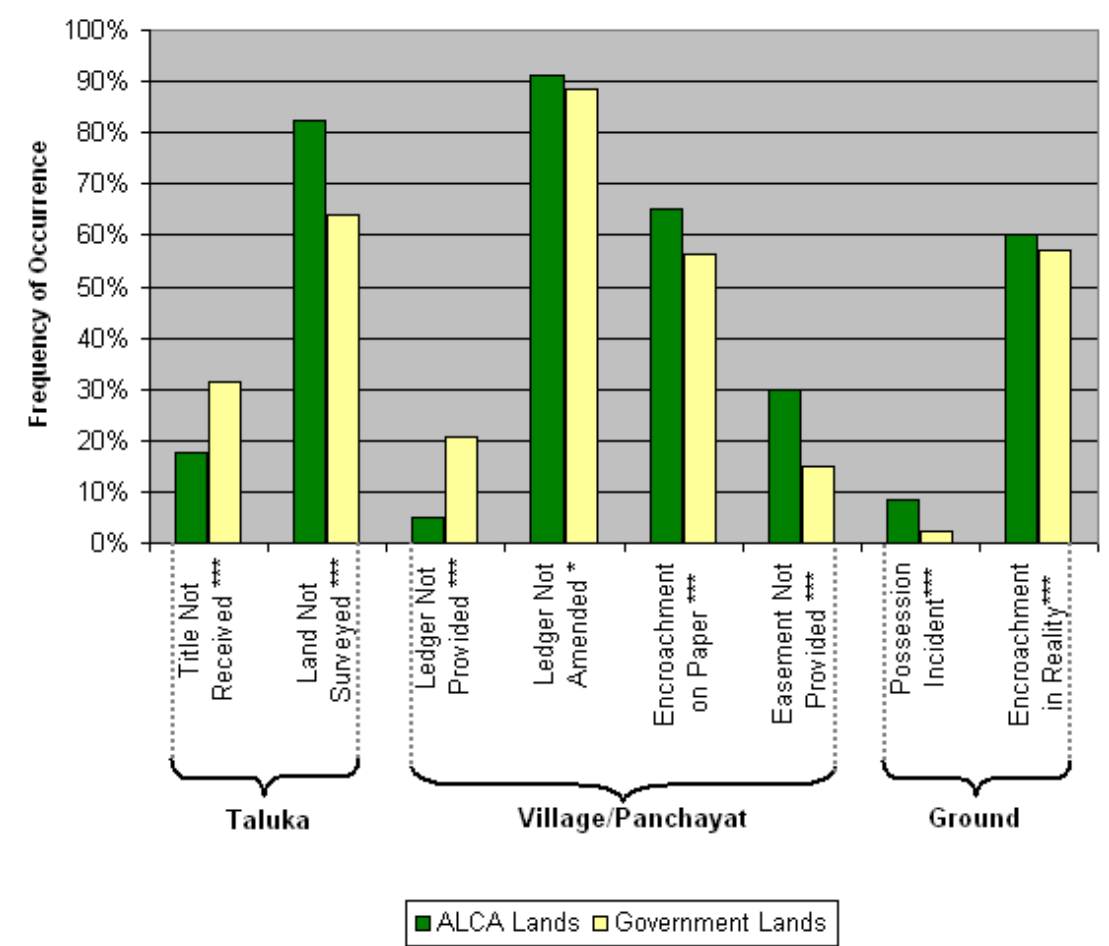

Figure 2.3-1. Breakdowns by land type at the taluka, village, and ground levels. $* * *=99 \%$ confidence level; $* *=95 \%$ confidence level; $*=90 \%$ confidence level. Source: Navsarjan 2006 survey, author's calculations.

\subsection{Social Outcomes of Land Reforms}

\subsubsection{Positive Social Outcomes}

While recipients of ALCA lands typically face greater hurdles to cultivation than do government lands recipients, they also generally reap the greatest social rewards. The left-hand side of Figure 2.4.1-1 shows that redistributed ALCA parcels are more effective at encouraging sedentism among migrant agricultural laborers, providing a feasible occupational alternative for manual scavengers, and boosting farmers' social and economic status. In Shiyen village, for example, the only Dalit farmer to receive ALCA lands had become markedly wealthier than his peers, and claimed openly to feel that his social status was better than theirs. In general, successful cultivators of redistributed lands, and especially richer ALCA lands, may find themselves in an advantageous 
position when applying for further lands in future. On the one hand, they will be familiar with the bureaucratic system and better able to navigate it. On the other hand, they may have made money from their farms with which to bribe crooked officials. ${ }^{24}$ In either case, a certain cumulative causation may kick in, countering the legal preference for the landless. ALCA recipients are, however, less likely to be in possession of their lands, probably for the reasons mentioned in Subsection 2.3.

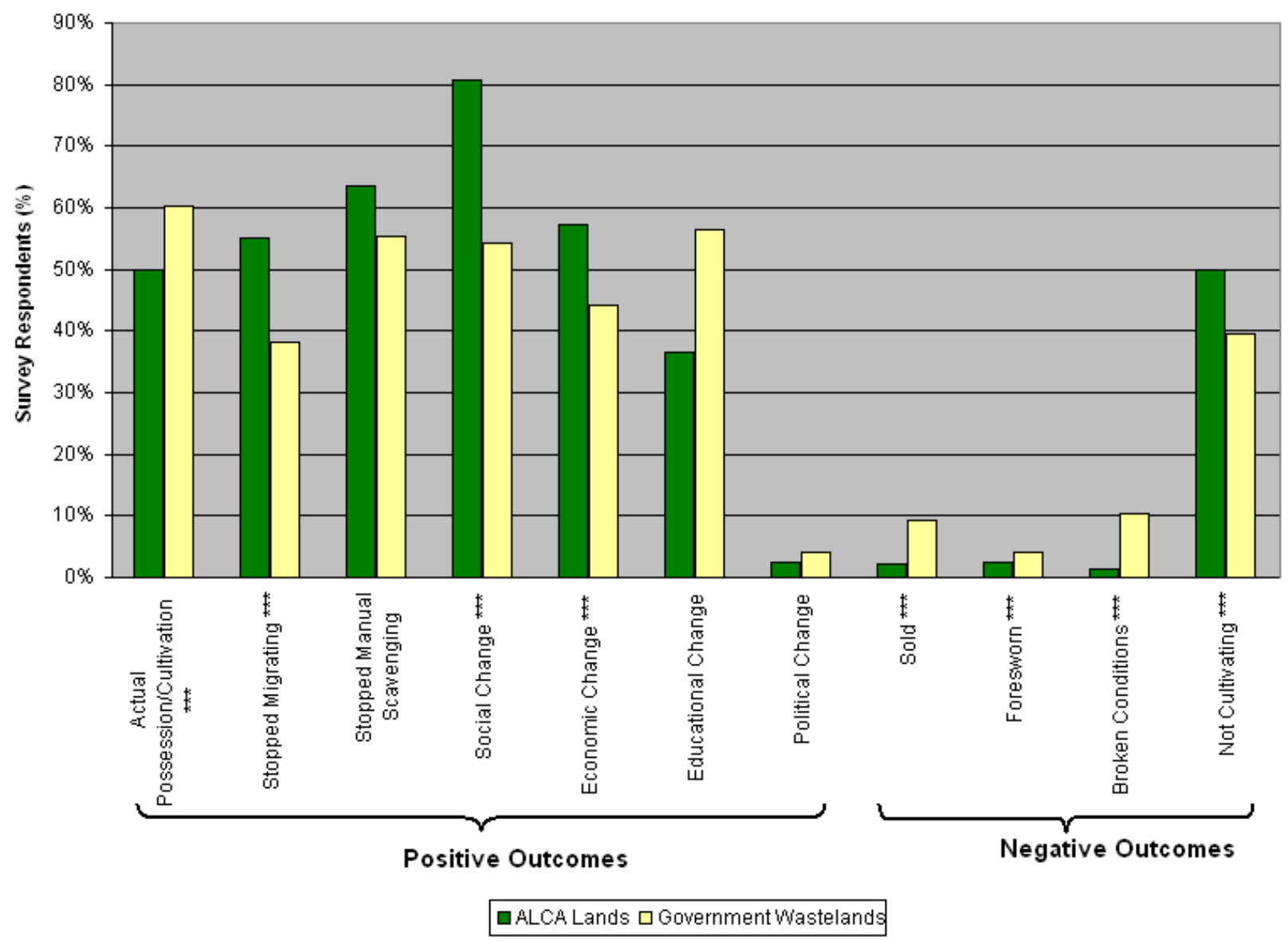

Figure 2.4.1-1. Positive and negative social outcomes of the land reforms by land type. $* * *=99 \%$ confidence level $; * *=95 \%$ confidence level; $*=90 \%$ confidence level. Source: Navsarjan 2006 survey, author's calculations.

\footnotetext{
${ }^{24}$ One Dalit recipient of 4 acres of ALCA lands in Kanpur later received twice the acreage of government wastelands that his Dalit peers received, despite being the only Dalit applicant already in possession of agricultural lands. The same year he received his government lands, Navsarjan workers report that the local Talati and Revenue Circle Officer were found to be collaborating on a shady arrangement whereby they would allot larger parcels for bribes. If the Kanpur Dalit paid these officials off to receive a larger share of government wastelands, he may have been able to do so because of his ALCA lands.
} 
This study had too few respondents to the questions on improvements in their or their family's educational or political status to generate statistically significant results.

However, if one can trust the tentative trend in responses obtained, government wasteland recipients more frequently reported educational or political advancement in their community for themselves or their family members. It is entirely consistent with the qualitative data obtained during the course of this study that agricultural laborers farming government land could both (a) not stop migrating completely and/or not have legal title to their promised lands, and (b) still experience educational and political advancement. Eight Dalit farmers interviewed in Vandavar village noted that they had mostly been migrant laborers prior to receiving awards for government wastelands in a dry wash. In fact, they never received title for the land, as a dam was subsequently constructed downstream, seasonally flooding the promised fields for six months of every year. They now lease the land on a yearly basis from the state. Thus, the Dalits now have no title and must also continue to migrate in search of work for half of the year. Despite these setbacks, however, they all reported educational, economic and social gains. In the words of one farmer:

Some of us have started small businesses, we have our kids in school, and we've built houses. We have more money, and this has led to social improvements. There is still a separate water well, though.

This quote hints at another ambiguity that runs through much of Navsarjan's work: does economic change precipitate social change, or vice versa? While the Dalits interviewed often saw economic improvement as a necessary precondition for social status improvement (as did the Dalit farmer quoted above), Navsarjan staff often emphasized the reverse-that social improvements were often more crucial as first steps. This 
ambiguity can be traced back all the way to the first Marxian interpretations of Caste, and Althusser's suggestion that in pre-capitalist societies, the superstructure may indeed dictate the dynamic of productive class formation. In fact, there is anecdotal evidence that both of these may be true in different circumstances. Navsarjan and the Dalits interviewed oftentimes view the dichotomy as a question of how broadly across the Dalit community the social status improvement spreads. For instance, in Kanpur, one economically successful Dalit land recipient is now allowed to take tea at the palace (a sign of social acceptance), though migrating Dalits are still barred from doing so. Thus, the economically successful are viewed as aberrations whose social status improvement may be tolerated, and does not significantly affect the broader social hierarchy. Conversely, the Shiyen community has known a more broad-based improvement in social standing that does not depend on case-by-case considerations of economic status. One possible reason is that the Shiyen Dalits are a fairly tight-knit community and advocate for one another, whereas the Kanpur Dalit community is more diffuse. As one Kanpur Dalit farmer surprisingly said:

None of my community really helped me out. Actually, the person who helped the most was the Sayla King's younger brother, who was progressive, had heard of Navsarjan's work, and has studied in the US, and he explained the situation to the Zamindar. A more strictly Marxian explanation is that the economic change in Shiyen just happened to affect a broader demographic, reached a critical mass, and thereby dictated a social paradigm shift. However, the socially-driven explanation seems to carry more weight. After all, more Dalits claimed to have experienced social improvement than to have experienced economic improvement. 
Dalit farmers almost always attributed educational advancement in the context of their families to the partial or total sedentism, and the resulting legal ability to enroll their children in the local school. This trend mirrors that seen in the "reservation," or affirmative action, system in Indian government: the largest benefits of the reservation are oftentimes reaped by the children of program beneficiaries through improved access to education (Wankhede 1999). Even in the case of the Vandavar Dalits who still migrate, their children no longer migrate with them, and attend elementary and even high school. Likewise, legal residency in a particular village grants to migrant agricultural laborers the ability to vote and to run for office. Many land recipients reported being members of the Gram Panchayat council, having joined political parties (even the BJP in some cases), and, in one case, becoming the village Sarpanch.

\subsubsection{Negative Social Outcomes}

By contrast, most of the redistribution "failures" occur more frequently with government lands than with ALCA lands (see Figure 2.4.1-1). Redistribution failures are here considered to be any outcome that does not result in the sustained cultivation of a redistributed parcel: selling, foreswearing, breaking title conditions, or (a catch-all category) not cultivating. In the case of government lands, each of these cases should theoretically result in the reversion of lands to government control. In fact, this seldom happens, and the lands instead become the de facto property of another claimant. The first three failures occur more often in the case of government lands, presumably because of the relatively low quality of the land (see Subsection 1.3.4). However, non-cultivation is more often seen with ALCA lands than with government lands, probably for a number 
of reasons relating to the competition for these valuable lands (some of which are discussed in Subsection 2.3).

The first failure, foreswearing one's claim to the land, is here presumed to be due to social pressure. This is because, whether by cultivating or selling the land, the rightful owner might have improved his or her financial position, but did not or could not. The second "failure" is the sale of one's land and the de facto end of sustained cultivation. State law interdicts the sale of redistributed lands for a period of fifteen years (Jindal 1982). However, interviews with Navsarjan staff and Dalit land recipients (as well as the survey data) reveal that the ban on selling early does not in fact prevent recipients from doing just that.

This practice often occurs as a variant on the following scenario: A beneficiary receives a plot, but for whatever reason, would rather sell it than cultivate it. He makes an arrangement with a buyer whereby he receives a portion of the agreed-upon sale price (most often 50\%) up front, in exchange for unofficially quitting the property. When the tenure comes of age, the deal is concluded, and the farmer receives the rest of the sale price in return for official title. None of the Dalits interviewed for this study testified to having charged interest on the outstanding balance, as would a bank with a mortgage loan. The sum thus simply depreciates for up to 15 years. In Chachka village, Limbdi taluka, for example, three Dalit families were given a combined 21 acres of ALCA lands, but sold them back to the original owners before the taluka surveyor even arrived, as they were unable to convince the original owners to quit the property and to take possession of it themselves (Navsarjan 2000). There are interesting variations on this theme, as well. 
In some villages, Dalit landowners are reportedly enticed to sell their long-term investments in return for jewelry or baubles. In Ori village, the Darbars continue to farm their former lands, but also effectively pay off the new Dalit owners with the "rent" of a small monthly share. In principle, this arrangement is not so far from a reversal of the Zamindari land tenancy system, except that the balance of power favors the tenant (instead of the landowner) and lowers therefore lowers the tenant's rent.

Dalit land sales do not automatically imply that social pressure is at work. Those Dalits interviewed for this study who had sold their land, generally did not sell it back to intractable upper-caste encroachers-at least not officially. Especially in the case of ALCA lands, large landholders legally stripped of their surplus lands prefer not to buy back their lands, for, while theoretically legal, this act automatically reactivates the ALCA's applicability to them and they may find their land again confiscated. They may, however, unofficially reassert control. The Darbar descendent of the Devaliya village zamindars, for instance, admitted that while his family officially owned exactly 54 acres per adult male (the legal limit), in reality, they controlled and cultivated much more. In any event, the reasons most often cited by Dalit land recipients for selling were high improvement costs and marginal land productivity—not social pressure or physical intimidation.

The third failure, breaking the terms of redistribution, occurs primarily when the rightful owner fails to cultivate his parcel for three consecutive years, or fails to pay revenue on the property. According to Dalit interviewees, both are symptoms of caste oppression. In Talsana village in Lakhtar taluka, for instance, members of the Darbar community 
reportedly intimidated one land recipient with the threat: "If you want to come cultivate it [the land], bring turmeric with you." 25 The non-payment of land revenue and inability to cultivate one's land are sometimes linked in a vicious cycle: if Dalit farmers are unable to cultivate their land, they will be disinclined effectively to pay someone else's taxes.

Navsarjan fieldworkers have also reported that some Talatis may purposefully refuse to take land revenue from Dalit land recipients, instead marking them as delinquent in their payments so that their tenure rights are revoked (Navsarjan 2000a).

\footnotetext{
${ }^{25}$ Turmeric is made into a poultice to treat wounds.
} 


\section{ACTIVISM AND INTERVENTION}

In the following section, I describe Navsarjan's organizational strategy (Subsection 3.1), its impact on our understanding of land redistribution success (Subsection 3.2). I argue that Navsarjan implicitly understands the nested game that plays out at various levels of government, and accordingly gears its strategy to modifying the linkages between levels such that Dalit farmers benefit. I then examine the weaknesses of the quantitative models employed in Section 2, in light of Navsarjan's strategy and anecdotal qualitative evidence (Subsection 3.1). I then examine avenues for future research (Subsection 3.3), and, in light of the findings, finally advance policy recommendations for the state and for Navsarjan as paradigmatic example of activist organizations dealing with land redistribution more generally (Subsection 3.4).

\subsection{Navsarjan's Three-Pronged Strategy}

In Navsarjan's December 1996 letter to the Surendranagar District Collector's office detailing cases of failure in land redistribution implementation (the precursor to the suit filed with the High Court of Gujarat in Ahmedabad in April of 1999), the group describes itself as follows:

"Navsarjan Trust" is a voluntary organization which provides assistance, education and legal aid to the poor people and also on the issues of violation of human rights [sic]. (Letter from Jamin Hakk Rakshan Samiti to the Surendranagar District Collector's Office, 23/12/1996, in Navsarjan 2000, 59) 
This statement cogently encapsulates not only the organization's purpose, but also its operational strategy. Rearranging the stated aspects of this strategy to align with the forgoing analysis of nested government (i.e., starting at the ground level and working up), we may state that the prongs of Navsarjan's advocacy offensive are:

- Education. Navsarjan employs fieldworkers whose primary responsibility is to inform Dalit villagers of their legal rights with respect to the land reforms and the other relevant legislation, such as the Prevention of Atrocities Act, 1989.

- Bureaucratic facilitation. Navsarjan fieldworkers inform village Dalits of lands that have been made available for redistribution, and help them to fill out and return the appropriate land redistribution forms.

- Legal aid. Navsarjan brings, or (often more effectively) threatens to bring, legal actions against non-performing government bodies.

These three prongs may roughly equate to three tiers of engagement: at the ground level, at the level of local government, and at the level of state government (through the court system). Because Navsarjan works simultaneously on these three tiers, the organization is able to choose at what level it will expend its limited resources for each particular challenge. While the first two prongs are quite time-intensive to , and imply a case-bycase tacticthe latter may demand a more generalizable complaint.

Education. Education consists of a mundane and a radical component. The mundane component involves the diffusion of legal knowledge to reduce information asymmetries in the struggle for socioeconomic equality. Rural Gujarat has a literacy rate of just 
$51.4 \%$, as compared to urban Gujarat's $71.2 \%^{26}$ (Census of India 2001). These numbers drop drastically for various minority groups. For instance, the literacy rate among Dalit women in India is just under 24\% (CEDAW 2005). ${ }^{27}$ Dalit farmers may not have easy access to, or even the ability to read, the local periodicals in which parcel availability is published.

The radical component to education is as necessary as it is difficult to quantify: bolstering the will of the Dalit community to stand up for their rights. As Navsarjan workers repeated told a group of Dalit farmers in Vanta Vachh village upon receiving a host of land-related complaints, "You must stand up and fight for your own issues—don't just tell us your woes." This "fighting spirit" has little to do with the size of the Dalit population—indeed, the percentage of Scheduled Castes as per the India Census 2001 never once proved a statistically significant determinant of breakdowns at any level. In Devaliya village in 2000 , for example, Dalits comprised around $8.1 \%$ of the total village population (Census India 2001)—a number that, while low for the sample population, is 1.2 percentage points higher than the rural Gujarati average. And yet, Devaliya is notorious for its caste-bound land relations and the firm grasp its Darbars keep on the reins of power. A tragic recent episode illustrated that low Dalit populations may not be the cause but rather the effect of land relations. In March of 2003, according to local Dalits, a brother of the Devaliya "village king" got into an altercation with a local Dalit who complained the brother was stealing large, construction-worthy stones from his land.

\footnotetext{
${ }^{26}$ It bears noting that both rural and urban literacy rates in Gujarat trail their national counterparts, which stand at 59\% and 80\% respectively (Census of India 2001).

${ }^{27}$ Human Rights Watch (2007) notes that the statistics reported to the Committee on the Elimination of Discrimination Against Women (CEDAW) on Dalit women's literacy are quite dated, deriving from the
} 
The Darbar formed a small band of friends who stabbed and killed the Dalit later that afternoon-a crime that has gone untried. Since that fateful day, local Dalits report anecdotally that about half of the Dalit residents fled for larger, nearby urban centers. A stroll through the former Dalit quarter confirms that many of the houses are still abandoned, or appropriated by other caste groups.

Navsarjan attributes many successes on the ground not to sheer Dalit numbers, but to the mindset of local Dalits, which, they contend, is fortified by knowledge of their legal rights and recourses. When asked why Darbars in Ori choose to bribe Dalits not to take possession of their rightful land, whereas Darbars in Talsana need only resort to open threats of physical violence, Navsarjan fieldworkers point to historical idiosyncrasies peculiar to each region that in turn manifest in differing expectations of what is possible in the minds of Dalits. In Talsana, they say, the Grahak, or bonded labor, system was particularly prevalent during Zamindari times, and landowner clout thus carries over into the present. Today's landowners still have many Dalits in their employ as bonded laborers, and it is to the latter that the landowners legally conceded their surplus lands upon the passage of the ALCA. The Dalits might legally own the surplus lands, but the Darbars essentially own the Dalits themselves through debt bondage. Thus, neither Darbar nor Dalit ever expected that the Dalits would ever truly receive possession.

Navsarjan employees also marshal other examples to emphasize the importance of Dalit mindsets in successful land redistribution. They say that in some villages, when Navsarjan originally brought the affidavit to Dalit farmers so that they could sign it and 
put their complaints on public record, the Dalits brought the documents straight to their landlord and asked him whether they should in fact sign. He advised them against it, and they backed down. In Ghanejada village, the taluka issued three consecutive orders to the Dalits to take possession of their allotted lands, but the Dalits refused. On the other hand, in Khadi village, one man fought for his rights and successfully took possession—an act that galvanized his peers to do likewise. As important as courage, will, and determination are, though, it is extremely difficult to measure them, nor did this survey even attempt to do so. Furthermore, even one could find an accurate metric for it, "strong will" may still be a confounding variable for knowledge of one's legal rights, or for Navsarjan's willingness to prosecute atrocities committed against Dalits.

Perhaps unsurprisingly, Navsarjan employees downplay the importance of Dalit mindset when speaking to local government officials, though. When the Talati of Sayla town asserted a very similar theory to that previously expressed by Navsarjan ("The subservient mindset of the Dalits themselves is the cause of their unwillingness to take possession of their lands.”), Navsarjan employees disagreed. They countered that the primary responsibility lay with the Taluka government and their powers of police protection during the delicate period of title transfer.

Bureaucratic facilitation. Navsarjan also functions to reduce Dalit transaction costs in navigating the bureaucracy of land administration. They do this first by informing Dalits of the land in the first place, and second by helping Dalits to fill out and submit the forms necessary to apply for the land, and to confirm title receipt (the latter serves to notify the to Gujarat. 
surveyor that the land is ready to be meted out). In some cases (e.g., Kanpur village) during the mid-1990s, when Navsarjan was just beginning to work on the land redistribution issue, District Collectors and Mamlatdars had recorded the award of land titles to Dalit beneficiaries, but the so-called "beneficiaries" themselves had not ever received word of the award. In such cases, Navsarjan also served to facilitate the flow of information down to the ground level. Thus, Navsarjan's efficacy is not only linked to its antagonistic role vis-à-vis the state, but also paradoxically its intercalation and embeddedness with the state that allows Navsarjan to increase the access to and effectiveness of government institutions for Dalits.

Legal aid. The PIL filed in 1999 illustrates that Navsarjan gives Dalits recourse to the law that they probably would not otherwise have. Furthermore, the suit was lent extra weight by the fact that Navsarjan was co-petitioner with "Jamin Hakk Rakshan Samiti," a group of affected citizens who banded together at Navsarjan's suggestion. In this way, Navsarjan's PIL carried the authenticity of a spontaneous local movement. While Navsarjan staff contend that they always aim to work alongside local communities in equal partnership, they also claim that Hamin Hakk Rakshan Samiti would never have been born without public awareness campaigns carried out by Navsarjan.

Of the 6,000 acres that the PIL originally singled out as not having been in the possession of the intended Dalit beneficiaries, just over 2,000 still remained in January of 2007 (though this number shifts depending on who is giving the information). Of course, the almost 4,000 acres that have since been restored to Dalits are not necessary under their cultivation, for a host of reasons discussed in Subsection 2.4.2. Nevertheless, the 
improvement appears to be drastic by all accounts. It is difficult to discern how much of this shift is due directly to the PIL, though. It could theoretically be argued that state government was making progress on the land reforms even in the absence of Navsarjan, or, barring that, that some other exogenous factor was introduced into the game at around the same time. Most of the Dalits interviewed, though, had received land titles or promises of land titles long before Navsarjan became involved in Surendrangar district in 1995. Most testified to the crucial role Navsarjan played in overcoming bureaucratic inertia or local community resistance. Some Dalits in Kanpur had effectively been in a holding pattern since their original application in 1967 when Navsarjan intervened in 1995, getting the promised land surveyed that same year. Likewise in Vanta Vachh, one man claimed that he originally faced resistance from the former landlord until Navsarjan interceded with the local government.

Navsarjan's role as bureaucratic facilitator also bleeds into its role as legal activist. For officially filing suit in the Gujarat High Court is merely at one (adversarial) extreme end of a spectrum of strategies designed to make use of government institutions. It also exemplifies one of Navsarjan's key strategies: to bypass local governments that are less amenable to their cause for higher-level governments that may bring pressure to bear on them. And while Navsarjan is currently contemplating filing further PILs, Navsarjan staff have observed that threatening to take legal action can oftentimes be as effective as actually taking it. This, they claim, is the case in Sayla Taluka, which used to be notorious for its regressive government, but whose officials now often consult Navsarjan before taking action on land reform issues. Navsarjan fieldworkers are even notified of opportunities to attend Sayla land surveys. Presumably, the Sayla mamlatdar, himself an 
upper caste-member, prefers satisfying Navsarjan directly to dealing with reproaches from the District Collector. The threat of legal action can also connect the legal aid strategy prong to that of educating Dalits to embolden them. In Nagarka village, in which hostility toward Dalit farmers was particularly strong, only one of 12 Dalit land recipients is today cultivating his land. Navsarjan attributes the success of that farmer to their promise of legal support in the case of an atrocity.

Whatever the reason, there has been a noticeable improvement in local governments' performance of those functions constituting land reform implementation from 1996 to 2006 (see Figure 3.1-1). ${ }^{28}$ Taluka and village governments showed remarkable improvement in all comparable categories, save that of granting title to ALCA lands, in which 1996 and 2006 exhibited roughly similar numbers (with percentages in the low 90s). Most strikingly, the general change trend (as depicted by red midpoint lines) seems to drift farther into positive territory at higher levels of government. The least amount of progress has been made at the ground level, with actual possession making modest but tangible gains, and non-encroachment (counting partial encroachments) remaining more or less unchanged.

\footnotetext{
${ }^{28}$ The 1996 and 2006 surveys had few directly corresponding questions. Furthermore, for reasons relating to 1996 data reporting, it is impossible to compare the same four talukas. Rather, the 1996 data refers to four talukas located nearby, but in different districts: Viramgam taluka in Ahmedabad district, Vallabhipur taluka in Bhavnagar district, Degham taluka in Gandhinagar district, and Jasdan taluka in Rajkot district. Nevertheless, Surendranagar district has the worst reputation in terms of land reform implementation (the reason Navsarjan started working there in the first place), and so if there is a regional bias, it will likely be against, rather than for, improvement in government performance during the intervening years.

The method of data reporting for the 1996 Navsarjan survey in the four Surendranagar talukas surveyed in 2006 was to report the absolute number of instances of government failures in the land reform implementation process. There was no sense of a denominator, and so failure rates as percentages were impossible to derive. This omission in itself may say something about Navsarjan's early approach to the issue, in that it seems part of a "name and shame" strategy designed to spur the government into action,. In other words, rather gauging the relative extent of the various problems, Navsarjan was more interested in
} 


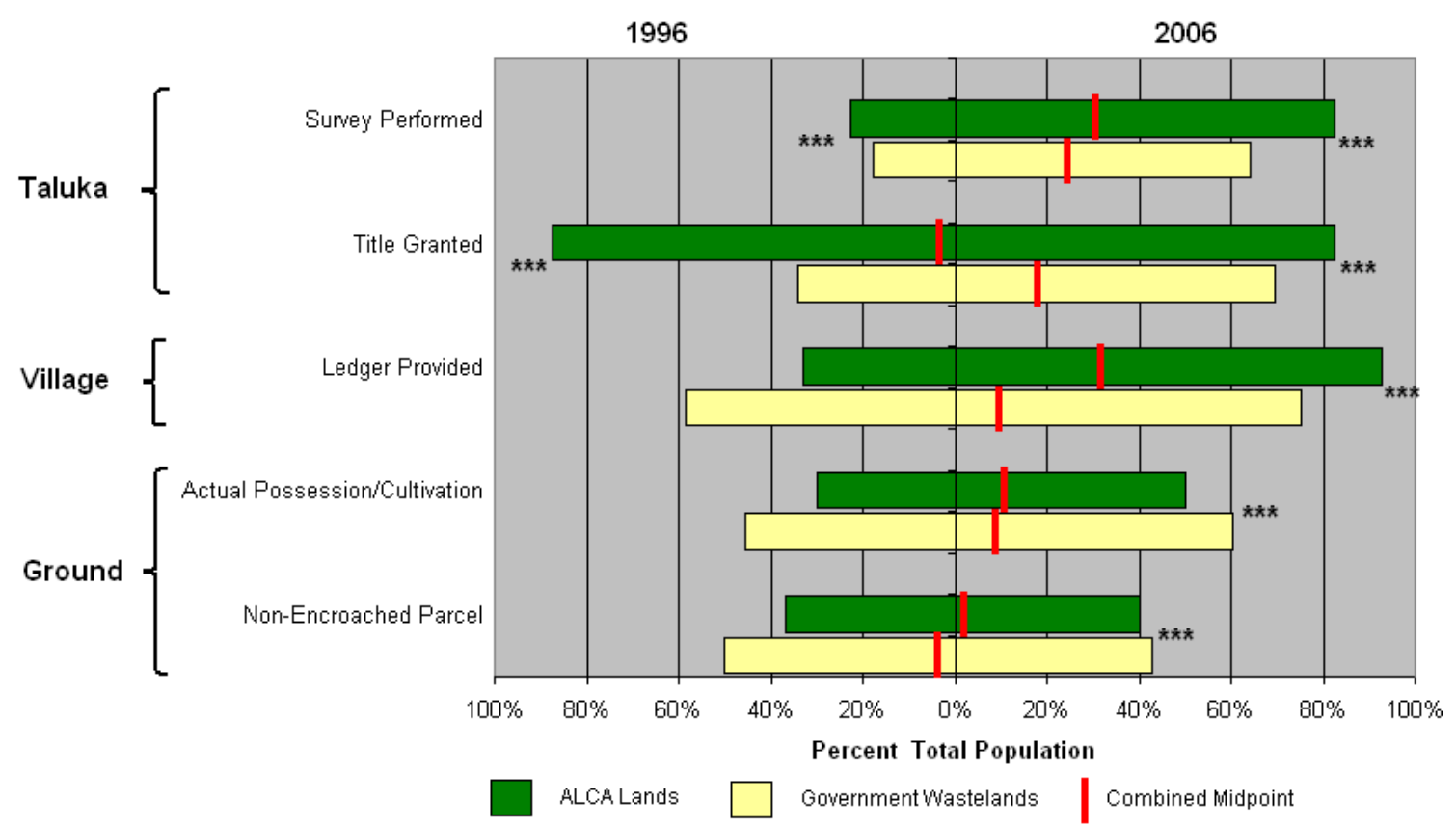

Figure 3.1-1. A comparison of survey responses for selected questions from 1996 and 2006. $* * *=99 \%$ confidence level; $* *=95 \%$ confidence level $; *=90 \%$ confidence level. These confidence levels refer to Chi-Square statistics between land types for the same year.

Source: Navsarjan 1996,2006 survey, author's calculations.

These change trends hint at two underlying phenomena. First, as I have argued in Section

$\mathbf{2}$, the government hierarchy represents a contested terrain, on which offices

geographically and institutionally closer to local elites may be more resistant to land reform, and offices more distant from local elites will be more susceptible to reform.

Second, assuming that Navsarjan is the primary catalyst of change, the trend may also reflect Navsarjan's strategy of selective engagement with various tiers of government. For while Navsarjan's tactics are not primarily top-down in nature, the aforementioned recalcitrance at lower levels of government (as well as the cost of trying to reform each of the hundreds of village governments in any given district) has the inevitable effect of driving the organization to focus increasingly on taluka, district, and state-level

pointing out that the problems existed at all. This "zero tolerance" view is echoed in their stance on manual 
government interventions. This shift of focus may then come to resemble the "trickledown" effect suggested by Figure 3.1-1.

\subsection{Implicit Critiques of Quantitative Land Reform Outcome Models}

Even the most robust of the quantitative models, that predicting variation in success rates of actual Dalit parcel possession and cultivation based on local socioeconomic factors and government obstacles (or "breakdowns"), was only able to explain about $57 \%$ of the statistical variation (see APPENDIX C, Table C-6). There must be other factors at work. This subsection considers a few categories of possible factors. These are: the influence of Navsarjan itself, other government bodies and programs, and social, historical and cultural dynamics.

Navsarjan's Influence. Subsection 3.1 introduces considerations of land reform success that were not taken into consideration in the quantitative analyses in Section 2. Most obviously and most generally, none of the effects of Navsarjan's own three-pronged efforts were assessed, whether disaggregated by prong or bundled. Simple lack of information on Navsarjan's program foci over the past 12 years is the principal cause of this omission. When asked if he would have been able to obtain his land without Navsarjan's help, though, one Kanpur Dalit said, "One hand needs the other to clap," hinting at Navsarjan's instrumental role in land reform.

Other Government Intervention. Other government priorities may in certain cases clash with that of land redistribution. The government departments overseeing the 
competing interests may not effectively coordinate with one another. In two villages visited for this study, Vanta Vachh and Vandavar, government wastelands identified for redistribution by the Agriculture Department were subsequently flooded by a dam built by a separate government agency. Also in Vanta Vachh, one Dalit (of a total of eight Dalit land recipients) received government wastelands from the Revenue Circle Officer only to have them rescinded by the district, which had reallocated the land to local businessman planning to dig a rock quarry there (ownership of minerals and extractive resources is reserved to the state).

Society and Culture. Many local social and cultural idiosyncrasies may also come to bear on the success of land reform legislation. Certain jatis are superstitious about scavengers, believing them to have mystical powers to curse the land. Navsarjan fieldworkers report that in Bhatuli village, for instance, a Vayisha caste-member received 12 acres under the Land Tenancy Act, but would not cultivate the land for fear of a Dalit curse. Scavengers cultivated four of the acres, and the landholder entreated them to remove the curse from the remaining eight acres by throwing them a feast.

It is also clear that Navsarjan places enormous emphasis on education and "Dalit mindsets" as key determinants of the success or failure of the land reforms in any particular village. Whether Navsarjan contributes in any way to bolstering these assets is a separate issue, but the fact remains that neither of these factors were considered.

Moreover, the broad category of "Dalit" may be too crude to allow for a sufficiently finegrained analysis. Specific jati identities of land recipients and land encroachers 
sometimes make a critical difference in the success of reforms. In Paccham village, Tanduka taluka, Ahmedabad district, for instance, about 40 Vankar (weaver) and 3 Bhangi (scavenger) families received redistributed lands in total. While the weaver families have known considerable success in cultivation, none of the scavenger families have been able to take possession. Nor do the two Dalit communities demonstrate solidarity in the face of caste discrimination, according to Navsarjan fieldworkers.

Finally, the specific social networks that Dalits and upper-castes form may prove decisive in a land dispute. The even distribution of titles to 54-acre parcels among all male family members over the age of 18 years is a common practice in large landholding families to avoid government confiscation of surplus lands. However, the Darbar "village king" of Tavi village claimed that his brother was not yet 18 when his lands came under scrutiny, and he had no one else to whom he could nominally cede his lands. By contrast, the Darbar "king" of Devaliya had a large extended family network that facilitated the shelter of many of his holdings. Thus, the presence or lack of "social capital" can hinder uppercaste ability to counter redistributive policies. Likewise, Dalits may form social networks, or may be more or less unified as a category.

\subsection{Avenues for Further Research}

Future research can build on the present study in a few important ways. It might make up for some of the methodological shortcomings of this study pointed out in Subsection 3.2, or it might make a more rigorous, quantitative assessment of asset ownership in rural Gujarat. Following the first tactic, future research might attempt first to assess Navsarjan's impact on land redistribution by measuring breakdowns in the path toward 
cultivation in a certain random sample of villages in which Navsarjan is active, and in a corresponding sample of villages in which Navsarjan does not operate. Certain methodological problems would arise: first, Navsarjan may not operate in a particular village, but still operate in that taluka or district. Second, other Dalit rights groups may concomitantly operate in certain villages. Third, it is not clear what criterion would be measured. Measuring obstacles thrown up to cultivation and the incidence of successful cultivation, as this study has done, does not necessarily speak to the larger issue of asset ownership by caste. This point is taken up again below. Further research might also attempt to boost the explanatory power of the models by measuring legal knowledge and "fighting spirit" of the Dalit community, taking into consideration the specific socioeconomic attributes of each Dalit land recipient (jati, income, asset ownership, etc.), and quantifying Navsarjan's own efforts in each village (whether by numbers of fieldworkers assigned per village, number of bureaucratic facilitations, etc.). Alternatively, an in-depth qualitative study might examine strong Dalit social networks to determine why they develop in certain villages and not in others.

Finally, any study on the land redistribution issue must certainly document actual land ownership by demographic group. Such an understanding would require complete land records for those areas studied to determine the percentage of land owned by Dalits, normalized by the percentage of Dalits in that population. Preferably, this would be done for multiple years over a given period stretching from before the PIL to after it, so that a time-elapse regression model could be constructed to gauge the effects of the PIL, and Navsarjan's other interventions. In effect, this tactic would yield a Gini coefficient of land ownership by which to measure socioeconomic progress. 


\subsection{Policy Recommendations}

As should now be clear, the line between the state and civil society in Gujarat is blurred with respect to land reform policy implementation. Instead of a neutral and monolithic state, we see that the state is a framework in which interests compete and in which groups like Navsarjan attempt to tip the scales in their cause's favor. The distinction between Navsarjan and the communities in which it works is also not perfectly clean, for while the group claims to be an organic outgrowth of the Dalit community, it does not merely reflect and communicate Dalit concerns. Rather, it continually pushes the edge of the envelope in formulating Dalit demands, while encouraging Dalit farmers to follow suitoften an act of defiance well outside the comfort zone of the community it purports to represent. While Navsarjan administration sometimes portrays caste conflict over land as occurring between righteous Dalits and activist groups on the one hand, and nefarious upper castes and the government on the other, in fact activists, farmers, and government form an uneasy triangle defined more by their intercalation and at times what Sanyal (1991) terms "antagonistic cooperation," than by their independence. Therefore, while policy recommendations are divided into those directed at the state and those directed at Navsarjan for the sake of convenience, the distinction at the margins is somewhat arbitrary.

\subsubsection{Policy Recommendations for the State}

- Codify variable land ceilings at the state level. Differential agricultural land quality demands a flexible system of land ceilings. In principle, state policy addresses this issue by allowing taluka mamlatdars to set local ceilings below the 
state level. In practice, this study has shown that different caste interests influence the taluka government. A mamlatdar who broke with precedent to introduce lower land ceilings would be seen as taking sides in this battle. Yet the need for variable land ceiling will only grow. The vast tracts of land to be brought under irrigation in the coming years due to the Narmada Canal scheme will effectively tilt the balance of agricultural power in favor of current landholders. Therefore, the state should mandate a variable land ceiling capable of accounting for soil quality, rainfall, and irrigation. Such a mandated policy application would effectively render the mamlatdar blameless in the eyes of local landholders.

- Centralize land records at the district and state levels. This policy recommendation stems from the fact that the talati and, recently, the mamlatdar are the only officials capable of identifying lands eligible for redistribution. With a more centralized land records system, preferably in the form of an updated geographic information system (GIS) capable of identifying overlapping and missing parcels, parcel ownership, and land quality, state oversight of ALCA lands declaration would be strengthened and local government accountability improved. Such a reform would have also to safeguard against caste interests influencing data entry and amendment.

- Conduct a participatory investigation of alleged surplus lands. With only $7.5 \%$ of originally estimated ALCA lands now declared and allotted, the state government should conduct an inventory to assess what became of the balance. The afore-mentioned GIS would greatly facilitate such an exercise. It is not 
inconceivable that the land ceiling policy simply precipitated a vast intra-familial decentralization of land ownership, while largely keeping the estates not only within the caste group, but within the family unit. If this is indeed the case, the state may need to consider a radical amendment to the current ALCA in order to accomplish the act's original aims. If intra-familial ownership decentralization is not the case, and lands were simply never even declared as surplus under the act, the state can then take the necessary steps to complete the implementation of the land reforms. Furthermore, such an inventory could be greatly aided by inviting anonymous tips and suspicions from local inhabitants - a parcel exceeding the land ceiling that had long gone without official recognition might be identified by local landless persons in the knowledge that they might apply for the parcel once made available under the ALCA.

- Create land disputes committees. The state should establish streamlined institutions for hearing and redressing encroachment complaints. Such institutions might take the form of standing land dispute committees, jointly run by local talukas and community groups. At present, survey complaints may be sent to the District Surveyor, and the talati and mamlatdar may deal with encroachment complaints on a tediously slow, case-by-case basis. Furthermore, upper-caste members may often simply take the matter to court, where the proceedings can drag on for 10 years or more, by which time the Dalit may have relented or been reduced to penury. With roughly $60 \%$ of Dalit land recipients reporting some form of encroachment, and recourse to the courts often prohibitively expensive and/or too time-consuming, it is imperative to create a 
standing mechanism to address systematically and expeditiously the numerous unresolved issues. Furthermore, if the committee were vested with the power to amend land ledgers, a major hurdle to credit access and successful cultivation could be overcome — at a $90 \%$ breakdown rate, the lack of ledger amendments is the most prevalent governmental obstacle to land reform implementation.

\subsubsection{Policy Recommendation for Navsarjan}

- Foster Dalit social networks. Navsarjan should work not just to educate and animate the Dalit fighting spirit, but also to coordinate their efforts and form their own social networks or even political party. In most villages visited during the course of this study, the Dalit community was badly splintered, and did not see itself as a cohesive power. Furthermore, Dalits often see the local "Zamindar" as more of a resource to be drawn upon than their peers. This view only perpetuates the patronage system. The formation of social networks, both within a single village (such as Jamin Hakk Rakshan Samiti) and among groups of villages, could provide an alternative resource to be utilized for agricultural products storage, access to sales markets, knowledge sharing, economies of scale in input purchases, and application of political pressure.

- Form regularized relations with all local governments. Navsarjan's relationship with the government of Sayla taluka, which consults Navsarjan on land reform implementation, should become a model for future relationships with local governments. Physical distance between different tiers of local government greatly contributes to breakdowns at the village levels. Since Navsarjan works 
regularly in many villages, they may serve as a communication link between government offices, effectively shrinking the distance. While Navsarjan does this to a certain extent at present by taking complaints to taluka officials and alerting them to the land reform derailments on the ground, the practice could be expanded in scope and regularized in terms of periodicity. Such a tactic might cast Navsarjan in a less adversarial light, and as more of an "antagonistic cooperator" (see, e.g., Sanyal 1991).

- Offer to help with land surveys. In the spirit of the previous suggestion, Navsarjan should explore the possibility of having its staff trained and certified in land surveying techniques, so as to offer its services to local taluka magistrates. In effect, Navsarjan would act as a progressive consulting service. Between $60-80 \%$ of Dalits surveyed reported that their land had not been surveyed, or had not been surveyed properly. Taluka governments have few surveyors, and sometimes have only one to cover tens or even hundreds of villages. It seems unlikely that Navsarjan could credibly charge the taluka government for such a service. Rather, a well-trained Navsarjan team, so long as it adhered to the strictest standards of objectivity in carrying out its duties, might provide Dalits and other land reform beneficiaries with proper surveys, while simultaneously lightening the workload for local taluka governments. Thus the interest of local governments and Navsarjan might be served simultaneously. 


\section{REFERENCES}

Agarwal, Bina (1994). A Field of One's Own: Gender and Land Rights in South Asia Cambridge: Cambridge University Press.

Ambedkar, B.R. (1944). The Annihilation of Caste with a Reply to Mahatma Gandhi.

Basu, Amrita and Atul Kohli (1998). Community Conflicts and the State in India. Delhi: Oxford University Press.

Berlin, Isaiah (1969). Four Essays on Liberty. Oxford: Oxford University Press.

Bremen, Jan (1985). Of Peasants, Migrants and Paupers: Rural Labor Migration and Capitalist Production in West India. Delhi: Oxford University Press.

Bremin, Jan (1975). Patronage and Exploitation: Changing Agrarian Relations in South Gujarat. Berkeley: University of California Press.

Buehler, G. trans. "The Laws of Manu" in Mueller, F. Max ed. Sacred Books of the East, Vol. XXV. Delhi: Motilal Banarsidass, 1964.

CEDAW, October 19, 2005, CEDAW/C/IND/2-3 para.110.

Dabhi, Parimal. "Securing Land Rights and Dignity." The Indian Express. 20

September 2005. Retrieved 21 October 2006 from www.indiaempowered.com.

Das, N.P. (2000). The Growth and Development of Scheduled Caste and Scheduled Tribe Population in Gujarat and Future Prospects. Baroda: University of Baroda. Accessed at http://www.iussp.org/Brazil2001/s40/S48_P07_Das.pdf on 15 February 2007.

Devi, Vasanthi. Dalits and the State. Frontline 17(14): 08 - 21July, 2000.

Ercegovac, Peter Anthony (1999). Competing National Ideologies, Cyclical Responses: The Mobilisation of the Irish, Basque and Croat National Movements to Rebellion Against the State. PhD Dissertation, University of Sydney.

Fernandes, Walter. 1996. The Emerging Dalit Identity: The Reassertion of the Subalterns. New Dehli: Indian Social Institute.

Gandhi, M.K. (1995). The Collected Works of Mahatma Gandhi: VOL. 98: 6 December, 1947 - 30 January, 1948. New Delhi: Ministry of Information and Broadcasting.

Geertz, Clifford (1973). The Interpretation of Culture. New York: Basic Books. Gellner Ernest (1983). Nations and Nationalism. Ithaca: Cornell University Press. 
“Their Tomorrow Never Comes." The Hindu Online. 29 December 2002. Retrieved 21 October 2006 from www.hinduonnet.com.

Horrowitz, Donald (2000). Ethnic Groups in Conflict. Berkeley: University of California Press.

Human Rights Watch (2007). Hidden Apartheid: Caste Discrimination Against India's "Untouchables." New York.

Klass, Morton (1980). Caste: The Emergence of the South Asian Social System.

Philadelphia: Institute for the Study of Human Issues.

Heilburn, James (1981). Urban Economics and Public Policy. $2^{\text {nd }}$ ed. New York: St. Martin's Press.

Ilaiah, Kancha (1996). Why I Am Not a Hindu: A Sudra Critique of Hindutva Philosophy, Culture and Political Economy. Mumbai: Sanya Press.

Iyer, Lakshmi (2003). The Impact of History and Institutions on Economic Development. $\mathrm{PhD}$ Dissertation, MIT.

Jayaraman, Raji and Peter Lanjouw (1998). The Evolution of Poverty and Inequality in Indian Villages. Washington, DC: The World Bank.

Jindal, M.L. ed. (1985). Gujarat Local Acts: 1827-1983. Jodhpur: India Publishing House.

Kohli, Atul, ed. (2001). The Success of India's Democracy. Cambridge: Cambridge University Press.

Kumar, Naresh. Shocking Story of How Hindu Rulers Cheated Dalits. Dalit Voice, 15 October 2006.

Majumdar, Sumit K. India Must Pay for Good Governance. Business Line, 23 June 2006. Retrieved on 01 March 2007 from

http://www.blonnet.com/2006/06/23/stories/2006062300891100.htm.

Mahurkar, Uday. "Making a Mockery of Redistribution.” India Today. 31 May 1997.

Marx, Karl (1976). Capital, Volume 1. London: Penguin Books.

Mearns, Robin and Saurabh Sinha (1999). Social Exclusion and Land Administration in Orissa, India. Washington, DC: The World Bank.

Mohanty, Manoranjan, ed. (2004). Caste, Class, Gender. Thousand Oaks, CA: Sage Publications. 
Mueller, F. Max, ed. (1964). Sacred Books of the East, Vol. XXV. Delhi: Motilal Bandarsidass.

Narula, Smita (1998). Caste Violence Against India's Untouchables. Washington, D.C.: Human Rights Watch.

National Campaign on Dalit Human Rights (1995). Broken Promises and Dalits Betrayed: Black Paper on the Status of Dalit Human Rights. New Delhi. Accessed at http://www.dalits.org/Blackpaper.html on 15 February 2007.

National Human Rights Commission (2004). Report on Prevention of Atrocities Against Scheduled Castes: Policy and Performance. New Delhi: National Human Rights Commission.

Navsarjan Trust (2000a). The Story of Land Reforms in Gujarat. Manuscript.

Navsarjan Trust (2000b). Migration in Search of Labor, Gujarat. Manuscript.

Omvedt, Gail (1994). Dalits and the Democratic Revolution: Dr. Ambedkar and the Dalit Movement in Colonial India. London: Sage Publications.

Omvedt, Gail, ed. (1982). Land, Caste \& Politics in Indian States. Delhi: Author's Guild Publications.

Patterson, Orlando. Context and Choice in Ethnic Allegiance: A Theoretical Framework and Caribbean Case Study. Ethnicity: Theory and Experience. Ed. Glazer, Nathan (1976). Cambridge, MA: Harvard University Press. 305-349.

Pradip, Manjula. Keynote address at the conference: "Virtual Slavery or Just a Job?: Tackling Manual Scavenging Through Technology, Law \& Development.” MIT, Cambridge, Massachusetts; 01 December 2006.

Rajagopal, Balakrishnan, et al. (2006). From Promise to Performance: Ecological Sanitation as a Step Toward Eliminating Manual Scavenging in India. Cambridge: The MIT Program on Human Rights \& Justice.

Rajagopal, Balakrishnan (2005). "Limits of Law in Counter-Hegemonic Globalization: The Indian Supreme Court and the Narmada Valley Struggle.” In de Sousa Santa, Boaventura and César A. Rodríguez-Garavito, eds. Law and Globalization from Below: Towards a Cosmopolitan Legality. Cambridge: Cambridge University Press, 183-217.

Rajagopal, Balakrishnan (2003). International Law from Below: Development, Social Movements, and Third World Resistance. Cambridge: Cambridge University Press. 
Sanyal, Bishwapriya (1991). Antagonistic Cooperation: A Case Study of Nongovernmental Organizations, Government and Donors' Relationships in IncomeGenerating Projects in Bangladesh. World Development 19(10), 1367-1379.

Sharuna, K.L. (1998). Caste, Feudalism \& Peasantry: The Social Foundation of Shekhawati. New Delhi: Manohar Publishers \& Distributors.

Shivakeri, Chandrakant D. (2004). Dr. B.R. Ambedkar's Political philosophy. New Dehli: Anmol Publications Pvt. Ltd.

Sikand, Yogi (2005). Dalits in Gujarat. Z Magazine, 15 November 2005.

Snyder, Jack (2000). From Voting to Violence: Democratization and Nationalist Conflict. New York: W.W. Norton \& Co.

Srivastava, Ravi S. (2006) Land Reforms, Employment and Poverty in India. The Hague: International Conference on Land, Poverty, Social Justice \& Development. 9-14 January 2006.

Tendler, Judith (1989). Whatever Happened to Poverty Alleviation? World Development 17(7), 1033-1044.

Tsebelis, George (1990). Nested Games: Rational Choice in Comparative Politics. Berkeley: University of California Press.

Varshney, Ashutosh (1995). Democracy, Development, and the Countryside: UrbanRural Struggles in India. Cambridge: Cambridge University Press.

Wankhede, G.G. (1999). Social Mobility and Scheduled Castes. New Delhi: Rawat Publications.

Weiner, Myron (2001). "The Struggle for Equality: Caste in Indian Politics," in Kohli, Atul, ed. (2001). The Success of India's Democracy. Cambridge: Cambridge University Press. 


\section{LIST OF TERMS}

Bhangi: Literally "Manual Scavengers," bhangi constitute the lowest sub-caste of the Dalits. They are considered in the ideology of purity and putrefaction to be the most impure sub-caste, and are charged with the manual removal from villages of human and animal feces, and the bodies of dead animals.

Brahman: The highest-ranking Varna, the Brahmans are the priestly class and have often claimed to be descendents of Indo-Aryans, who are believed to have migrated to the subcontinent in the second millennium BCE.

Chamar: The middle-ranked of three Dalit sub-castes, the Chamar are traditionally restricted to the occupation of skinning animals, preparing hides, and leatherworking.

Dalit: Literally "Broken People," Dalits are also referred to as Parjanya, Antyaja, "untouchables," "outcastes," and, in legal terms, "Scheduled Castes" in reference to the fact that they do not belong to a Varna caste. They fall outside of the Varna system, but nonetheless rank lower than all Varna in social practice. The term 'Dalits' as used in Gujarat encompasses three major subgroups (again listed in descending order of purity): the Weavers (Vankar), the Leatherworkers (Chamar), and the Scavengers (Bhangi) (ibid.). They may self-identify as Hindu, Muslim, or Christian.

Gram panchayat: Local government of a village.

Kamin: Refers to the lower castes in the jajmani system.

Kilvaram: The "lower share" of the land revenues in the Zamindari system, which nonBrahman landowners could keep for themselves.

Kshtriya: The second-highest ranking Varna and the "Warrior Caste." The Kshtriya have traditionally been kings and warriors, and were collectively considered by the British to exhibit certain personality traits, such as fidelity, honor, pride, courage, belligerence, and physical strength.

Jajman: Refers to the upper caste patrons in the jajmani system.

Jajmani system: A system of caste patronage regulating social interaction among castes based on the concepts of purity and putrefaction. The jajmani system is seen by some scholars as mere exploitation clothed, while others (see, e.g., Bremin 1975) contend that it constituted a vehicle for caste bargaining (albeit one weighted in favor of upper castes). The name refers to the upper-caste patrons, or Jajmans. The lower castes were referred to as Kamin.

Jati: Literally "births," jatis are sub-castes that fall theoretically, though not always neatly, within the Varna system. Distinctions are based on occupation acceptable for adoption by group members. 
Mamlatdar: A taluka-level official charged with overseeing the implementation of the Land Ceiling Act. His office also includes a Revenue Circle Officer and a surveyor.

Melvaram: The "upper share" of the land revenues in the zamindari system, which Brahmans were owed by non-Brahman zamindars.

Mleccha: Refers to those areas antagonistic to the Brahmanical system during the spread of Buddhist kingdoms during the Buddhist Magatha-Maurya empires from the 7th to 2nd centuries BCE.

Panchayat: A grouping of five villages in a quincunx, headquartered at a central village.

Panchayat samiti: The government of a taluka.

Sarparch: The mayor of a village or gram panchayat.

Scheduled Castes: The legal term for 'Dalit,' so called because they fall under the definition and protections set forth in the Fifth Schedule of the Indian constitution.

Scheduled Tribes: The legally defined indigenous peoples of India, so called because they fall under the definition and protections set forth in the Fifth Schedule of the Indian constitution.

Sudra: The fourth and lowest Varna in the caste system, composed of farmers and agriculturalists.

Talati: A panchayat-level official charged with land revenue collection and identification of landholding in excess of the land ceiling.

Taluka: A sub-District level unit of local government that generally consists of a central town, potentially other towns, and a number of villages. The government of a taluka is referred to as a panchayat samiti.

Toch Maryadha: Government "wastelands" deemed cultivable and distributed to vulnerable beneficiaries under the Government Lands Programme.

Vaishya: The third-highest Varna, or caste, composed of merchants, traders, and retailers.

Vankar: Literally "Weavers," the highest sub-caste of the Dalits, whose appointed occupation is the cleaning and weaving of wool.

Varna: The Hindu religious system of broad caste groupings. The term also refers to classes of broad caste groupings themselves. These latter include, in descending order of purity, Brahman (scholars, teachers and priests), Kshtriya (kings, vassals and warriors), Vaishya (merchants, traders, and retailers), and Sudra (agriculturalists and farmers). The Varna are said to correspond to the various parts of the body of the divinity Purasha, from 
which they are derived. Thus, Brahmans were made from the head, Kshtriya from the arms, Vaishya from the torso, and Sudra from the legs. Outside of the Varna system, but nonetheless ranked lower than all Varna in social practice, are the Dalits.

Zamindari system: Land revenue system under which absentee feudal landlords, or Zamindars, collected revenues for the Mughal and British governments from renters. The latter in turn used employed and bonded labor to cultivate the fields. 
Table A-1. Land redistribution efforts in various Indian states, with scheduled caste recipients extracted.

Total

Redistribution

Area Area

('000s Recipients ('000s Recipients \% Share \% Share of \% Share \% Share of Average

\begin{tabular}{|c|c|c|c|c|c|c|c|c|c|}
\hline State & Ac.) & ('000s) & Ac.) & $\left({ }^{6} 000 \mathrm{~s}\right)$ & of Area & Recipients & of Area & Recipients & Area \\
\hline $\begin{array}{l}\text { Andhra } \\
\text { Pradesh }\end{array}$ & 594.4 & 521.6 & 226.9 & 216.5 & 38.2 & 41.5 & 12.6 & 121.7 & 10.4 \\
\hline Assam & 479.9 & 441.8 & 45.7 & 43.4 & 9.5 & 9.8 & 2.5 & 2.3 & 1.1 \\
\hline Bihar & 303.2 & 372.5 & 179.2 & 229.8 & 59.1 & 61.7 & 9.9 & 12.4 & 0.8 \\
\hline Gujarat & 134.0 & 31.4 & 83.2 & 14.6 & 62.1 & 46.5 & 4.6 & 0.8 & 5.2 \\
\hline Haryana & 87.3 & 27.4 & 37.6 & 11.8 & 43.1 & 42.9 & 2.1 & 0.6 & 3.2 \\
\hline $\begin{array}{l}\text { Himachal } \\
\text { Pradesh } \\
\text { Jammu \& }\end{array}$ & 3.3 & 4.4 & 2.3 & 2.9 & 69.0 & 66.7 & 0.1 & 0.2 & 0.8 \\
\hline Kashmir & 45.0 & 450.0 & 0 & 0 & 0.0 & 0.0 & 0.0 & 0.0 & 0.0 \\
\hline Karnataka & 117.1 & 31.4 & 71.1 & 19.0 & 60.7 & 60.3 & 3.9 & 1.0 & 3.8 \\
\hline $\begin{array}{l}\text { Kerala } \\
\text { Madhya }\end{array}$ & 64.3 & 145.1 & 25.2 & 62.2 & 39.0 & 42.8 & 1.4 & 3.4 & 0.4 \\
\hline Pradesh & 185.3 & 72.1 & 49.4 & 21.5 & 26.7 & 29.8 & 2.7 & 1.2 & 2.3 \\
\hline Maharashtra & 554.9 & 14.6 & 161.7 & 41.9 & 29.1 & 29.8 & 8.9 & 2.3 & 3.9 \\
\hline Orissa & 154.3 & 135.2 & 49.1 & 45.6 & 31.8 & 33.7 & 2.7 & 2.5 & 1.1 \\
\hline Punjab & 103.5 & 28.3 & 44.0 & 11.3 & 42.5 & 40.0 & 2.4 & 0.6 & 3.9 \\
\hline Rajasthan & 452.2 & 77.9 & 145.3 & 28.5 & 32.1 & 36.5 & 8.0 & 1.5 & 5.1 \\
\hline Tamil Nadu & 162.4 & 135.2 & 62.1 & 59.7 & 38.2 & 44.2 & 3.4 & 3.2 & 1.0 \\
\hline Uttar Pradesh & 390.5 & 346.2 & 263.8 & 236.6 & 67.6 & 68.3 & 14.6 & 12.8 & 1.1 \\
\hline West Bengal & 965.3 & $2,151.6$ & 359.5 & 800.9 & 37.2 & 37.2 & 19.9 & 43.3 & 0.4 \\
\hline Total & $5,213.3$ & $5,120.9$ & $1,807.6$ & 1848.8 & 34.7 & 36.1 & 100.0 & 100.0 & 1.0 \\
\hline Mean & 282.2 & 293.3 & 106.3 & 108.6 & 40.4 & 40.7 & 5.9 & 12.3 & 2.6 \\
\hline Median & 162.4 & 135.2 & 62.1 & 41.9 & 38.2 & 41.5 & 3.4 & 2.3 & 1.1 \\
\hline
\end{tabular}

Source: Report of the National Commission for SCs/STs, 1995-1996, extracted in Thorat, Social Security for SCs in unorganized sector in S.M. Dev \& others, Social and Economic Security in India, 2001, p. 371 Delhi. 


\section{APPENDIX B: LAND REFORM IMPLEMENTATION ORGANIGRAMS}

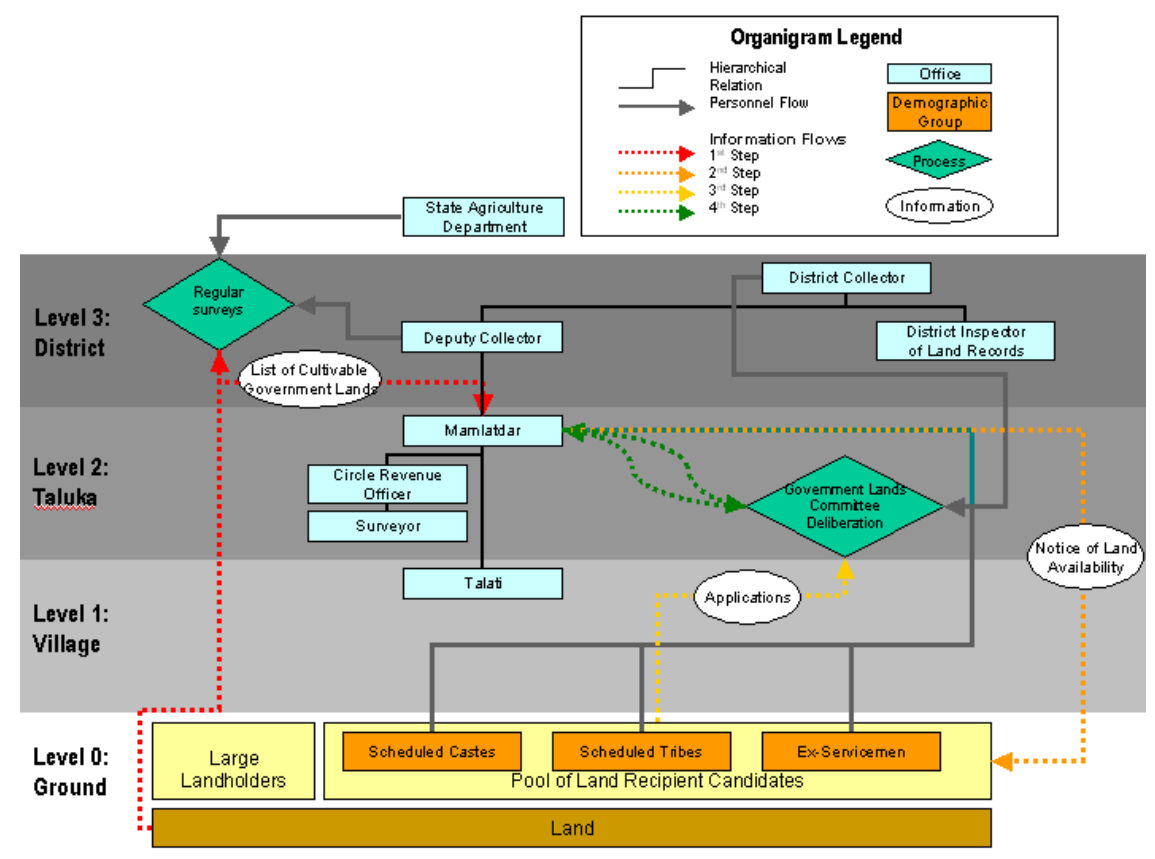

Figure B-1. Organigram of the assessment and selection process for land redistribution under the ALCA.

Source: the author.

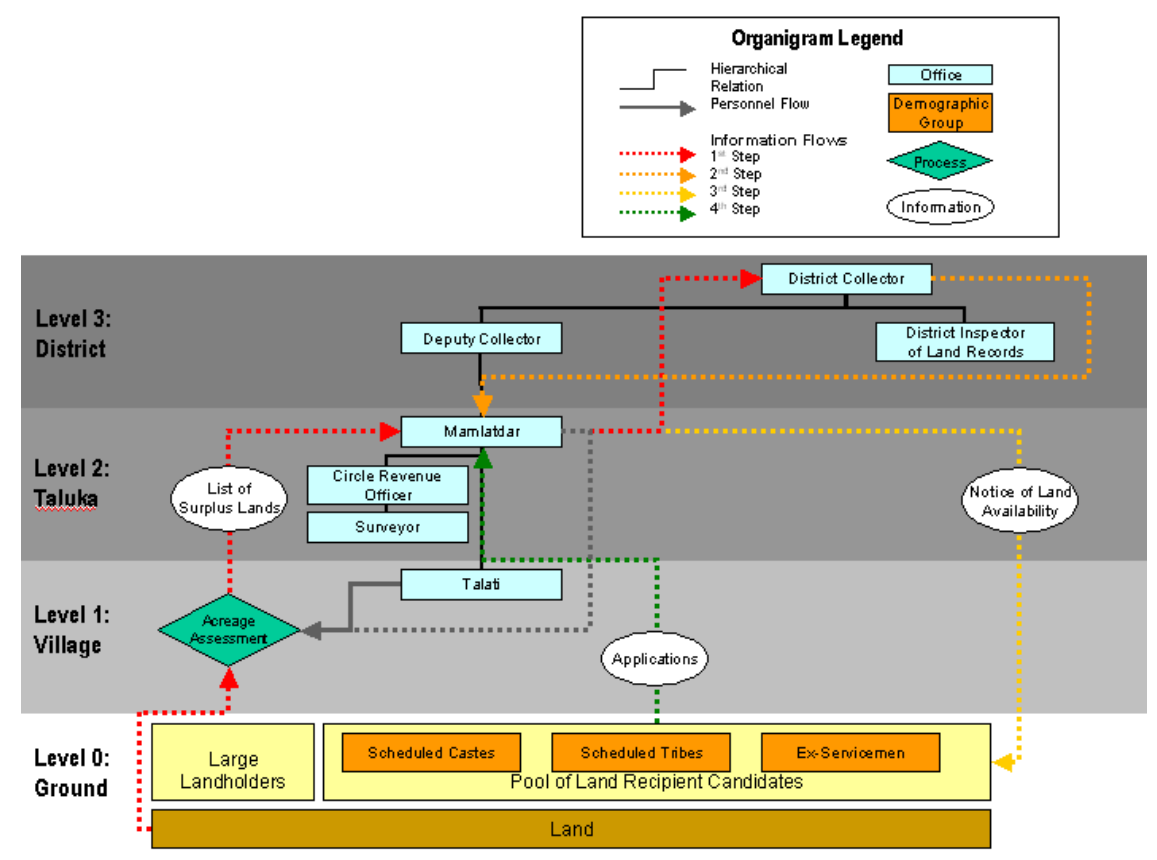

Figure B-2. Organigram of the assessment and selection process for land redistribution under the ALCA.

Source: the author. 


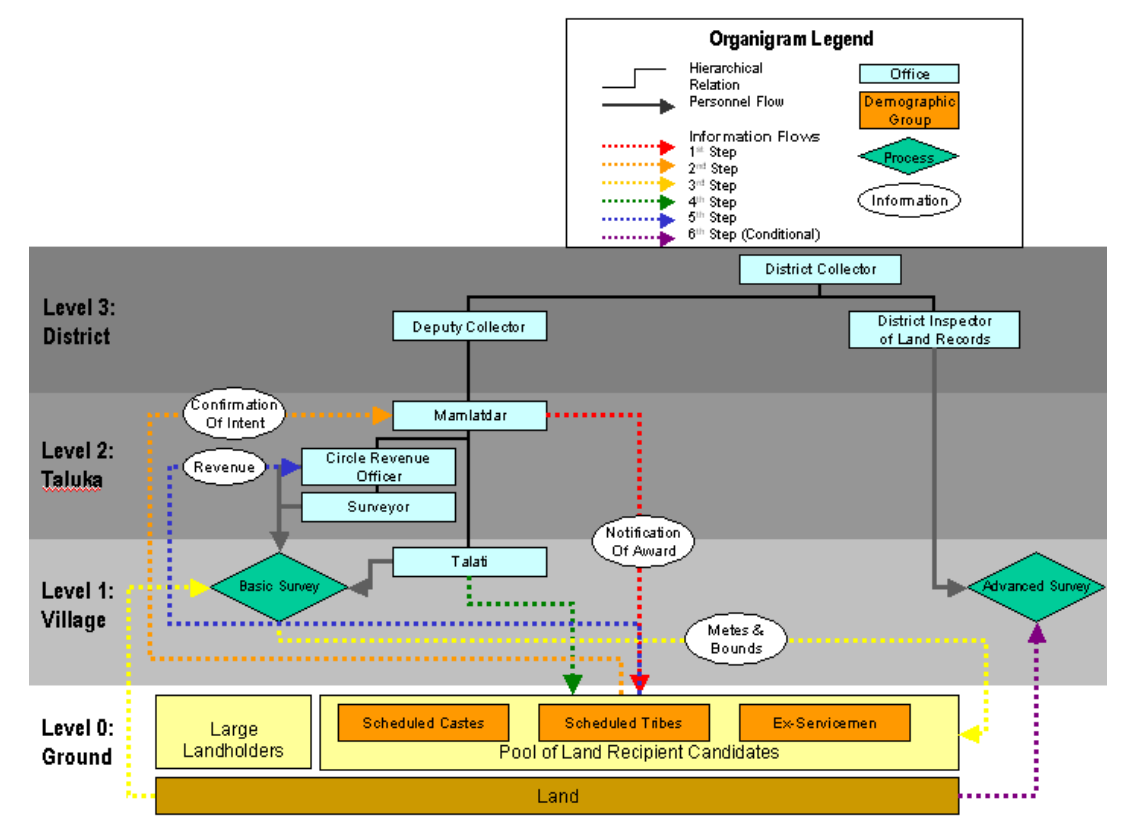

Figure B-3. Organigram of the implementation process for land redistribution under both the ALCA and Government Lands Programme.

Source: the author. 


\section{APPENDIX C: REGRESSION RESULTS FOR SECTION 2}

Tables C-1. Regression results for determinants of breakdowns at the ground level.

\begin{tabular}{|c|c|c|c|}
\hline Model & Variables Entered & $\begin{array}{l}\text { Variables } \\
\text { Removed }\end{array}$ & Method \\
\hline 1 & $\begin{array}{l}\text { BPL_20_Cumperc, TalHQ-DHQ_Distance, MargAL_perc, GovBD_14, } \\
\text { Val/Ac, Land Type, MainAL_perc, Workers_perc, TalukaHQ_Dist(a) }\end{array}$ & & Enter \\
\hline
\end{tabular}

a All requested variables entered.

b Dependent Variable: GovBD_02

\section{Model Summary}

\begin{tabular}{|l|l|r|r|r|}
\hline Model & $\mathrm{R}$ & $\mathrm{R}$ Square & $\begin{array}{c}\text { Adjusted R } \\
\text { Square }\end{array}$ & $\begin{array}{c}\text { Std. Error of } \\
\text { the Estimate }\end{array}$ \\
\hline 1 & $.647(\mathrm{a})$ & .418 & .386 & .39408 \\
\hline
\end{tabular}

a Predictors: (Constant), BPL_20_Cumperc, TalHQ-DHQ_Distance, MargAL_perc, GovBD_14, Val/Ac, Land Type, MainAL_perc, Workers_perc, TalukaHQ_Dist

\begin{tabular}{|c|c|c|c|c|c|c|}
\hline \multicolumn{7}{|c|}{ ANOVA(b) } \\
\hline Model & & $\begin{array}{l}\text { Sum of } \\
\text { Squares }\end{array}$ & df & Mean Square & $\mathrm{F}$ & Sig. \\
\hline 1 & $\begin{array}{l}\text { Regressio } \\
\mathrm{n} \\
\text { Residual } \\
\text { Total }\end{array}$ & $\begin{array}{l}17.991 \\
25.004 \\
42.994\end{array}$ & $\begin{array}{r}9 \\
161 \\
170\end{array}$ & $\begin{array}{r}1.999 \\
.155\end{array}$ & 12.871 & $.000(a)$ \\
\hline
\end{tabular}

a Predictors: (Constant), BPL_20_Cumperc, TalHQ-DHQ_Distance, MargAL_perc, GovBD_14, Val/Ac, Land Type, MainAL_perc, Workers_perc, TalukaHQ_Dist

b Dependent Variable: GovBD_02

\section{Coefficients(a)}

\begin{tabular}{|c|c|c|c|c|c|c|}
\hline \multirow[b]{2}{*}{ Model } & & \multicolumn{2}{|c|}{$\begin{array}{l}\text { Unstandardized } \\
\text { Coefficients }\end{array}$} & \multirow{2}{*}{$\begin{array}{c}\text { Standardized } \\
\text { Coefficients } \\
\text { Beta }\end{array}$} & \multirow[b]{2}{*}{$\mathrm{t}$} & \multirow[b]{2}{*}{ Sig. } \\
\hline & & $\mathrm{B}$ & Std. Error & & & \\
\hline \multirow[t]{10}{*}{1} & (Constant) & -1.169 & .322 & & -3.630 & .000 \\
\hline & Land Type & -.222 & .067 & -.219 & -3.311 & .001 \\
\hline & $\mathrm{Val} / \mathrm{Ac}$ & .000 & .000 & .129 & 1.904 & .059 \\
\hline & TalukaHQ_Dist & -.023 & .006 & -.310 & -4.072 & .000 \\
\hline & $\begin{array}{l}\text { TalHQ- } \\
\text { DHQ_Distance }\end{array}$ & .009 & .003 & .180 & 2.653 & .009 \\
\hline & Main $\bar{A} L \_p e r c$ & 1.013 & .542 & .126 & 1.869 & .063 \\
\hline & MargAL_perc & 2.508 & .658 & .244 & 3.809 & .000 \\
\hline & Workers_perc & 1.675 & .429 & .266 & 3.906 & .000 \\
\hline & GovBD_14 & .295 & .041 & .448 & 7.124 & .000 \\
\hline & $\begin{array}{l}\text { BPL_20_Cump } \\
\text { erc }\end{array}$ & 2.213 & .551 & .306 & 4.016 & .000 \\
\hline
\end{tabular}

a Dependent Variable: GovBD_02 
Tables C-2. Two-stage least squares analysis of the effects of village-level government breakdowns in land redistribution on ground-level breakdowns.

MODEL: MOD_1.

$-$

Equation number: 1

Dependent variable.. GovBD_02

Listwise Deletion of Missing Data

Multiple R $\quad .44461$

R Square $\quad .19768$

Adjusted R Square $\quad .19293$

Standard Error $\quad .45179$

Analysis of Variance:

\begin{tabular}{|c|c|c|c|}
\hline & DF & Sum of Squares & Mean Squar \\
\hline Regression & & 8.498878 & 8.498877 \\
\hline Residuals & 169 & 34.495274 & .2041140 \\
\hline
\end{tabular}

$F=41.63789 \quad$ Signif $F=.0000$

Variables in the Equation -----------------

$\begin{array}{llllll}\text { Variable } & \text { B } & \text { SE B } & \text { Beta } & \text { T } & \text { Sig T } \\ \text { GovBD_14 } & .293006 & .045408 & .444607 & 6.453 & .0000 \\ \text { (Constant) } & -.099244 & .131035 & -.757 & .4499 & \end{array}$

Correlation Matrix of Parameter Estimates

$$
\text { GovBD_14 }
$$

GovBD_14 1.0000000 
Tables C-3. Determinants of Breakdowns at the Village Level

\begin{tabular}{|l|r|r|r|}
\hline Model & Variables Entered/Removed(b) & Mariables \\
& Removed & Method \\
\hline 1 & $\begin{array}{r}\text { Lit_perc, BPL_20_Cumperc, MargAL_perc, GovBD_22, TalHQ- } \\
\text { DHQ_Distance, TalukaHQ_Dist, BPL_15_Cumperc(a) }\end{array}$ & & Enter \\
& $\cdot$ & \\
\hline
\end{tabular}

a All requested variables entered.

b Dependent Variable: GovBD_14

Model Summary

\begin{tabular}{|l|l|r|r|r|}
\hline Model & $\mathrm{R}$ & R Square & $\begin{array}{c}\text { Adjusted R } \\
\text { Square }\end{array}$ & $\begin{array}{c}\text { Std. Error of } \\
\text { the Estimate }\end{array}$ \\
\hline 1 & $.597(\mathrm{a})$ & .357 & .339 & .647 \\
\hline
\end{tabular}

a Predictors: (Constant), Lit_perc, BPL_20_Cumperc, MargAL_perc, GovBD_22, TalHQ-DHQ_Distance, TalukaHQ_Dist, BPL_15_Cumperc

ANOVA(b)

\begin{tabular}{|r|r|r|r|r|r|r|}
\hline \multicolumn{1}{|l|}{ Model } & \multicolumn{1}{c|}{$\begin{array}{c}\text { Sum of } \\
\text { Squares }\end{array}$} & df & Mean Square & \multicolumn{1}{c|}{ F } & Sig. \\
\hline 1 & Regressio & 60.145 & 7 & 8.592 & 20.500 & $.000(\mathrm{a})$ \\
& $\mathrm{n}$ & 108.552 & 259 & .419 & & \\
& Residual & 168.697 & 266 & & & \\
& Total & & & \\
\hline
\end{tabular}

a Predictors: (Constant), Lit_perc, BPL_20_Cumperc, MargAL_perc, GovBD_22, TalHQ-DHQ_Distance,

TalukaHQ_Dist, BPL_15_Cumperc

b Dependent Variable: GovBD_14

Coefficients(a)

\begin{tabular}{|c|c|c|c|c|c|c|}
\hline \multirow[b]{2}{*}{ Model } & & \multicolumn{2}{|c|}{$\begin{array}{l}\text { Unstandardized } \\
\text { Coefficients }\end{array}$} & \multirow{2}{*}{$\begin{array}{c}\text { Standardized } \\
\text { Coefficients } \\
\text { Beta }\end{array}$} & \multirow[b]{2}{*}{$\mathrm{t}$} & \multirow[b]{2}{*}{ Sig. } \\
\hline & & $\mathrm{B}$ & Std. Error & & & \\
\hline \multirow[t]{8}{*}{$\overline{1}$} & $\overline{\text { (Constant) }}$ & 1.286 & .283 & & 4.543 & .000 \\
\hline & GovBD_22 & .397 & .046 & .454 & 8.676 & .000 \\
\hline & $\begin{array}{l}\text { BPL_15_Cump } \\
\text { erc }\end{array}$ & -2.343 & 1.079 & -.184 & -2.171 & .031 \\
\hline & $\begin{array}{l}\text { BPL_20_Cump } \\
\text { erc }\end{array}$ & 2.690 & 1.119 & .214 & 2.405 & .017 \\
\hline & TalukaHQ_Dist & .013 & .007 & .109 & 1.756 & .080 \\
\hline & $\begin{array}{l}\text { TalHQ- } \\
\text { DHQ Distance }\end{array}$ & .015 & .004 & .212 & 3.670 & .000 \\
\hline & MargAL_perc & 1.687 & .767 & .113 & 2.199 & .029 \\
\hline & Lit_perc & 1.241 & .473 & .152 & 2.624 & .009 \\
\hline
\end{tabular}

a Dependent Variable: GovBD_14 
Tables C-4. Determinants of Breakdowns at the Taluka Level (Without Easements)

Variables Entered/Removed(b)

\begin{tabular}{|l|c|c|c|}
\hline Model & Variables Entered & $\begin{array}{c}\text { Variables } \\
\text { Removed }\end{array}$ & Method \\
\hline 1 & SC_perc, TalHQ-DHQ_Distance, BPL_20_Cumperc, Acres(a) & & Enter \\
\hline
\end{tabular}

a All requested variables entered.

b Dependent Variable: GovBD_22

Model Summary

\begin{tabular}{|l|c|r|r|r|}
\hline Model & $\mathrm{R}$ & R Square & $\begin{array}{c}\text { Adjusted R } \\
\text { Square }\end{array}$ & $\begin{array}{c}\text { Std. Error of } \\
\text { the Estimate }\end{array}$ \\
\hline 1 & $.345(\mathrm{a})$ & .119 & .106 & .849 \\
\hline
\end{tabular}

ANOVA(b)

\begin{tabular}{|r|r|r|r|r|r|r|}
\hline Model & & $\begin{array}{c}\text { Sum of } \\
\text { Squares }\end{array}$ & df & Mean Square & \multicolumn{1}{c|}{ F } & \multicolumn{1}{c|}{ Sig. } \\
\hline 1 & Regressio & 27.108 & 4 & 6.777 & 9.402 & $.000(\mathrm{a})$ \\
& $\mathrm{n}$ & 278 & .721 & & \\
& Residual & 200.384 & 282 & & & \\
\hline & Total & 227.492 & 282 & & \\
\hline
\end{tabular}

a Predictors: (Constant), SC_perc, TalHQ-DHQ_Distance, BPL_20_Cumperc, Acres

b Dependent Variable: GovBD_22

\section{Coefficients(a)}

\begin{tabular}{|c|c|c|c|c|c|c|}
\hline \multirow[b]{2}{*}{ Model } & & \multicolumn{2}{|c|}{$\begin{array}{c}\text { Unstandardized } \\
\text { Coefficients }\end{array}$} & \multirow{2}{*}{$\begin{array}{c}\begin{array}{c}\text { Standardized } \\
\text { Coefficients }\end{array} \\
\text { Beta } \\
\end{array}$} & \multirow[b]{2}{*}{$\mathrm{t}$} & \multirow[b]{2}{*}{ Sig. } \\
\hline & & B & Std. Error & & & \\
\hline \multirow[t]{5}{*}{$\overline{1}$} & (Constant) & .394 & .177 & & 2.230 & .027 \\
\hline & Acres & -.048 & .015 & -.193 & -3.263 & .001 \\
\hline & $\begin{array}{l}\text { BPL_20_Cump } \\
\text { erc }\end{array}$ & 3.972 & .862 & 272 & 4.609 & .000 \\
\hline & $\begin{array}{l}\text { TalHQ- } \\
\text { DHQ Distance }\end{array}$ & .013 & .005 & .160 & 2.752 & .006 \\
\hline & SC_perc & -1.902 & .614 & -.185 & -3.100 & .002 \\
\hline
\end{tabular}

a Dependent Variable: GovBD_22 
Tables C-5. Breakdowns at the Taluka Level (With Easements)

Variables Entered/Removed(b)

\begin{tabular}{|l|r|r|r|}
\hline Model & Variables Entered & $\begin{array}{c}\text { Variables } \\
\text { Removed }\end{array}$ & Method \\
\hline 1 & $\begin{array}{r}\text { Lit_perc, BPL_20_Cumperc, MainAL_perc, TalHQ-DHQ_Distance, } \\
\text { TalukaHQ_Dist, SC_perc, DistrictHQ_Dist(a) }\end{array}$ & & Enter \\
\hline
\end{tabular}

a All requested variables entered.

b Dependent Variable: GovBD_23

Model Summary

\begin{tabular}{|l|l|r|r|r|}
\hline Model & $\mathrm{R}$ & R Square & $\begin{array}{c}\text { Adjusted R } \\
\text { Square }\end{array}$ & $\begin{array}{c}\text { Std. Error of } \\
\text { the Estimate }\end{array}$ \\
\hline 1 & $.462(\mathrm{a})$ & .214 & .193 & .81235 \\
\hline
\end{tabular}

a Predictors: (Constant), Lit_perc, BPL_20_Cumperc, MainAL_perc, TalHQ-DHQ_Distance,

TalukaHQ_Dist, SC_perc, DistrictHQ_Dist

\section{ANOVA(b)}

\begin{tabular}{|r|r|r|r|r|r|r|}
\hline Model & & \multicolumn{1}{c|}{$\begin{array}{c}\text { Sum of } \\
\text { Squares }\end{array}$} & df & Mean Square & \multicolumn{1}{c|}{$\mathrm{F}$} & \multicolumn{1}{c|}{ Sig. } \\
\hline 1 & Regressio & 46.504 & 7 & 6.643 & 10.067 & $.000(\mathrm{a})$ \\
& $\mathrm{n}$ & 259 & .660 & & \\
& Residual & 170.918 & 259 & & & \\
& Total & 217.422 & 266 & & & \\
\hline
\end{tabular}

a Predictors: (Constant), Lit_perc, BPL_20_Cumperc, MainAL_perc, TalHQ-DHQ_Distance,

TalukaHQ_Dist, SC_perc, DistrictHQ_Dist

b Dependent Variable: GovBD_23

\section{Coefficients(a)}

\begin{tabular}{|c|c|c|c|c|c|c|}
\hline \multirow[b]{2}{*}{ Model } & & \multicolumn{2}{|c|}{$\begin{array}{c}\text { Unstandardized } \\
\text { Coefficients }\end{array}$} & \multirow{2}{*}{$\begin{array}{c}\begin{array}{c}\text { Standardized } \\
\text { Coefficients }\end{array} \\
\text { Beta }\end{array}$} & \multirow[b]{2}{*}{$\mathrm{t}$} & \multirow[b]{2}{*}{ Sig. } \\
\hline & & B & Std. Error & & & \\
\hline \multirow[t]{8}{*}{1} & (Constant) & 1.055 & .450 & & 2.344 & .020 \\
\hline & $\begin{array}{l}\text { BPL_20_Cump } \\
\text { erc }\end{array}$ & 2.094 & 1.030 & .147 & 2.033 & .043 \\
\hline & TalukaHQ_Dist & .045 & .012 & .327 & 3.854 & .000 \\
\hline & DistrictHQ_Dist & -.039 & .009 & -.458 & -4.427 & .000 \\
\hline & $\begin{array}{l}\text { TalHQ- } \\
\text { DHQ_Distance }\end{array}$ & .024 & .006 & .303 & 4.094 & .000 \\
\hline & Main $\bar{A} L \_$perc & 3.921 & .869 & .278 & 4.513 & .000 \\
\hline & SC_perc & -2.031 & .725 & -.196 & -2.801 & .005 \\
\hline & Lit_perc & -1.606 & .812 & -.174 & -1.979 & .049 \\
\hline
\end{tabular}

a Dependent Variable: GovBD_23 
Table C-6. Determinants of Redistribution Failure ${ }^{29}$

Variables Entered/Removed(b)

\begin{tabular}{|c|c|c|c|}
\hline Model & Variables Entered & $\begin{array}{l}\text { Variables } \\
\text { Removed }\end{array}$ & Method \\
\hline 1 & $\begin{array}{r}\text { TalHQ_Sq, MainAL_perc, Khat_Change, Easement_Dummy, } \\
\text { EncrRem_Dummy, Workers_perc, MargAL_perc, Land Type, } \\
\text { Poss_Dummy, Val/Ac, TalHQ-DHQ_Distance, BPL_05_perc, TOT_P, } \\
\text { EncrRemGR_Dummy, BPL_15_Cumperc, SC_perc, } \\
\text { DistrictHQ_Dist(a) }\end{array}$ & & Enter \\
\hline
\end{tabular}

a All requested variables entered.

b Dependent Variable: Dal_04

\section{Model Summary}

\begin{tabular}{|l|l|r|r|r|}
\hline Model & $\mathrm{R}$ & R Square & $\begin{array}{c}\text { Adjusted R } \\
\text { Square }\end{array}$ & $\begin{array}{c}\text { Std. Error of } \\
\text { the Estimate }\end{array}$ \\
\hline 1 & $.782(\mathrm{a})$ & .612 & .567 & .52152 \\
\hline
\end{tabular}

a Predictors: (Constant), TalHQ_Sq, MainAL_perc, Khat_Change, Easement_Dummy, EncrRem_Dummy, Workers_perc, MargAL_perc, Land Type, Poss_Dummy, Val/Ac, TalHQ-DHQ_Distance, BPL_05_perc,

TOT_P, EncrRemGR_Dummy, BPL_15_Cumperc, SC_perc, DistrictHQ_Dist

ANOVA(b)

\begin{tabular}{|c|c|c|c|c|c|c|}
\hline Model & & $\begin{array}{l}\text { Sum of } \\
\text { Squares }\end{array}$ & $\mathrm{df}$ & Mean Square & $F$ & Sig. \\
\hline 1 & $\begin{array}{l}\text { Regressio } \\
\mathrm{n} \\
\text { Residual } \\
\text { Total }\end{array}$ & $\begin{array}{r}62.601 \\
39.710 \\
102.311\end{array}$ & $\begin{array}{r}17 \\
146 \\
163\end{array}$ & $\begin{array}{r}3.682 \\
.272\end{array}$ & 13.539 & $.000(a)$ \\
\hline
\end{tabular}

a Predictors: (Constant), TalHQ_Sq, MainAL_perc, Khat_Change, Easement_Dummy, EncrRem_Dummy, Workers_perc, MargAL_perc, Land Type, Poss_Dummy, Val/Ac, TalHQ-DHQ_Distance, BPL_05_perc,

TOT_P, EncrRemGR_Dummy, BPL_15_Cumperc, SC_perc, DistrictHQ_Dist

b Dependent Variable: Dal_04

\footnotetext{
29 "Failure" here is taken to mean the combined instances of no land cultivation, or having foresworn, sold or otherwise broken the conditions of ownership of a parcel.
} 
Coefficients(a)

\begin{tabular}{|c|c|c|c|c|c|c|}
\hline \multirow[b]{2}{*}{ Model } & & \multicolumn{2}{|c|}{$\begin{array}{l}\text { Unstandardized } \\
\text { Coefficients }\end{array}$} & \multirow{2}{*}{$\begin{array}{c}\text { Standardized } \\
\text { Coefficients } \\
\text { Beta }\end{array}$} & \multirow[b]{2}{*}{$\mathrm{t}$} & \multirow[b]{2}{*}{ Sig. } \\
\hline & & $B$ & Std. Error & & & \\
\hline \multirow[t]{18}{*}{$\overline{1}$} & (Constant) & -.856 & .650 & & -1.317 & .190 \\
\hline & Land Type & -.191 & .118 & -.120 & -1.609 & .110 \\
\hline & Poss_Dummy & -.168 & .136 & -.076 & -1.234 & .219 \\
\hline & Easement_Du & -.751 & .280 & -.147 & -2.678 & .008 \\
\hline & Khat_Change & .253 & .098 & .148 & 2.590 & .011 \\
\hline & $\begin{array}{l}\text { EncrRem_Dum } \\
\text { my }\end{array}$ & .624 & .142 & .364 & 4.395 & .000 \\
\hline & $\begin{array}{l}\text { EncrRemGR_D } \\
\text { ummy }\end{array}$ & -.939 & .158 & -.529 & -5.927 & .000 \\
\hline & $\mathrm{Val} / \mathrm{Ac}$ & .000 & .000 & .165 & 2.602 & .010 \\
\hline & TOT_P & .000 & .000 & .513 & 7.146 & .000 \\
\hline & BPL_05_perc & -54.407 & 25.222 & -.274 & -2.157 & .033 \\
\hline & $\begin{array}{l}\text { BPL_15_Cump } \\
\text { erc }\end{array}$ & 3.426 & 1.353 & .282 & 2.533 & .012 \\
\hline & DistrictHQ_Dist & -.037 & .009 & -.542 & -4.223 & .000 \\
\hline & MainAL_perc & -4.173 & .816 & -.329 & -5.114 & .000 \\
\hline & MargAL_perc & -2.766 & 1.100 & -.171 & -2.515 & .013 \\
\hline & SC_perc & 2.154 & .873 & .259 & 2.467 & .015 \\
\hline & Workers_perc & 4.011 & .745 & .410 & 5.386 & .000 \\
\hline & $\begin{array}{l}\text { TalHQ- } \\
\text { DHQ Distance }\end{array}$ & .009 & .007 & .115 & 1.270 & .206 \\
\hline & TalHQ̄_Sq & .002 & .000 & .392 & 4.290 & .000 \\
\hline
\end{tabular}

a Dependent Variable: Dal_04 